\title{
Endometrial wave-like activity in assisted reproduction
}

Citation for published version (APA):

van Gestel, I. (2008). Endometrial wave-like activity in assisted reproduction. [Doctoral Thesis, Maastricht University]. Datawyse / Universitaire Pers Maastricht. https://doi.org/10.26481/dis.20081204ig

Document status and date:

Published: 01/01/2008

DOI:

10.26481/dis.20081204ig

Document Version:

Publisher's PDF, also known as Version of record

\section{Please check the document version of this publication:}

- A submitted manuscript is the version of the article upon submission and before peer-review. There can be important differences between the submitted version and the official published version of record.

People interested in the research are advised to contact the author for the final version of the publication, or visit the DOI to the publisher's website.

- The final author version and the galley proof are versions of the publication after peer review.

- The final published version features the final layout of the paper including the volume, issue and page numbers.

Link to publication

\footnotetext{
General rights rights.

- You may freely distribute the URL identifying the publication in the public portal. please follow below link for the End User Agreement:

www.umlib.nl/taverne-license

Take down policy

If you believe that this document breaches copyright please contact us at:

repository@maastrichtuniversity.nl

providing details and we will investigate your claim.
}

Copyright and moral rights for the publications made accessible in the public portal are retained by the authors and/or other copyright owners and it is a condition of accessing publications that users recognise and abide by the legal requirements associated with these

- Users may download and print one copy of any publication from the public portal for the purpose of private study or research.

- You may not further distribute the material or use it for any profit-making activity or commercial gain

If the publication is distributed under the terms of Article $25 \mathrm{fa}$ of the Dutch Copyright Act, indicated by the "Taverne" license above, 


\title{
Endometrial
}

\author{
wave-like \\ activity \\ in assisted \\ reproduction
}

\section{Proefschrift}

Ter verkrijging van de graad van doctor aan de Universiteit Maastricht, op gezag van de Rector Magnificus, prof. mr. G.P.M.F. Mols, volgens het besluit van het College van Decanen, in het openbaar te verdedigen op donderdag 4 december 2008 om 14:00 uur door

Iris van Gestel

Geboren 8 aprit 1970 te Venray

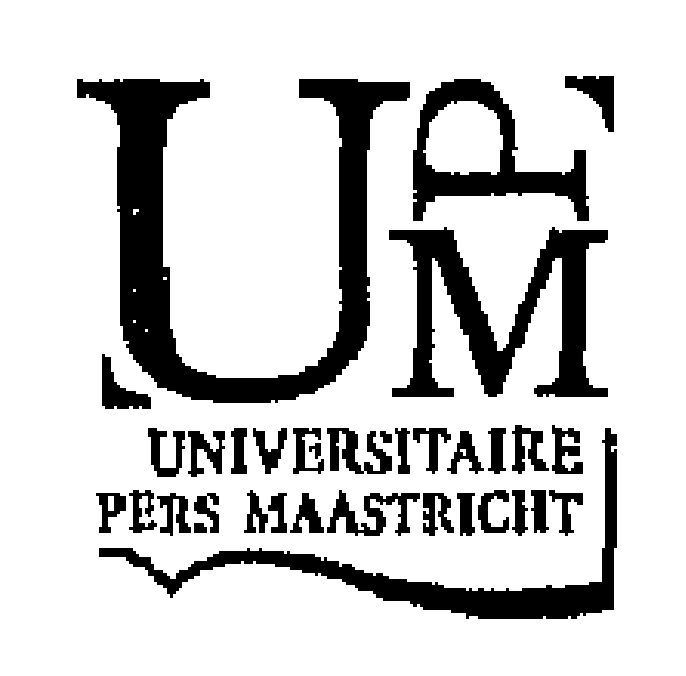


Promotor

Prof. Dr. J.L.H. Evers

Copromotores

Or. H.J. Hoogland

Dr. M.M. IJland

\section{Beoordelingscommissie}

Prof. Dr. J.M.A. van Engelshoven (voorzitter)

Dr. P.X.J.M. Bouckaert

Prof. Dr. A. Hoeks

Prof. Dr. S.G. Oei

Prof. Dr. A.J.J.A. Scherpbier 


\section{Contents}

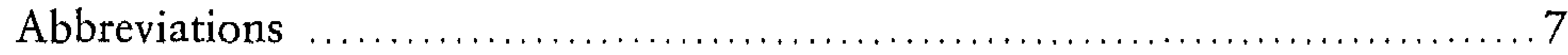

Chapter $1 \rrbracket 1.1$ General introduction ................................... 8

$\$ 1.2$ Aims of this thesis ..................................... 16

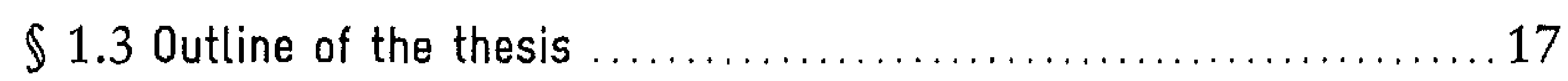

Chapter 2 Endometrial wave-like activity in the non-pregnant uterus $\ldots \ldots \ldots \ldots 18$

Chapter 3 Endometrial waves in in vitro fertilization cycles.

A validation study. ........................................44

Chapter 4 Complex endometrial wave-patterns in IVF ......................5 54

Chapter 5 Influence of intra-uterine manipulation on endometrial

wave-like activity .......................................66 66

$\$ 5.1$ Introduction .............................................68

$\$ 5.2$ Embryo transfer does not influence the direction

of endometrial waves .................................... 70

$\$ 5.3$ Intra-uterine manipulation does not adversely

influence the direction and frequency of endometrial waves .....73

Chapter 6 Endometrial waves fail to predict IVF outcome in a prospective study... 84

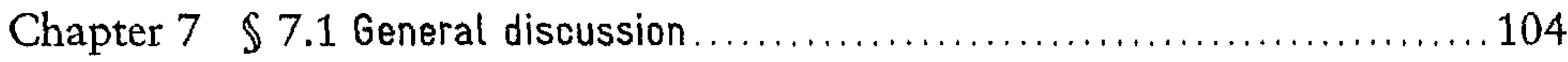

$\$ 7.2$ Future perspectives .................................. 113

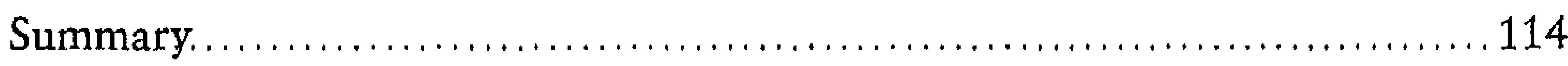

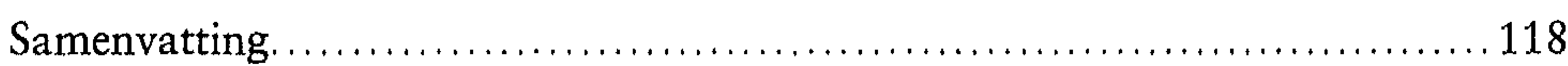

Curriculum.Vitae ................................................ 122

Dankwoord ...................................................... 124 


\section{Abbreviations}

$\begin{array}{llll}\text { A } & \text { amplitude of contractions } & \text { IVF } & \text { in vitro fertilization } \\ \text { abd } & \text { abdominal } & \text { MRI } & \text { magnetic resonance imaging } \\ \text { B } & \text { basal pressure of contractions } & \text { No Act } & \text { no activity } \\ \text { BID } & \text { bis in die (twice a day) } & \text { Not classif } & \text { not classifiable } \\ \text { CD } & \text { cycle day } & \text { NPV } & \text { negative predicitive value } \\ \text { Cl } & \text { confidence interval } & \text { NS } & \text { not significant } \\ \text { CF } & \text { cervix to fundus } & \text { OPP } & \text { opposing } \\ \text { COS } & \text { controlled ovarian stimulation } & \text { OPU } & \text { ovum pick-up } \\ \text { D } & \text { duration of contractions } & \text { PG } & \text { prostaglandin } \\ \text { DV } & \text { digital video } & \text { PPV } & \text { positive predictive value } \\ \text { E2 } & \text { estradiol } & \text { R } & \text { random } \\ \text { ET } & \text { embryo transfer } & \text { rFSH } & \text { recombinant follicle } \\ \text { F } & \text { frequency of contractions } & & \text { stimulating hormone } \\ \text { FC } & \text { fundus to cervix } & \text { RR } & \text { relative risk } \\ \text { Gn } & \text { gonadotropin } & \text { Spont } & \text { spontaneous cycles } \\ \text { GnRHa } & \text { gonadotropin releasing } & \text { S-VHS } & \text { super Vertical Helican Scan } \\ & \text { hormone analogue } & \text { TC diff } & \text { time-code difference } \\ \text { hCG } & \text { human chorionic ganadotropin } & \text { US } & \text { ultrasound } \\ \text { hMG } & \text { human menopausal gonadotropin } & \text { vag } & \text { vaginal } \\ \text { I } & \text { intensity of contractions } & \text { WDS } & \text { wave direction switch } \\ \text { IUI } & \text { intra-uterine insemination } & & \end{array}$


Chapter 1

General 
introduction 


\section{1 \\ General introduction}

The endometrium, the inner lining of the uterus, plays an important role in human reproduction. During the menstrual cycle the endometrium thickens and proliferates under the influence of steroid hormones, with the sole purpose of hosting a potential pregnancy. Various aspects of the cyclic endometrial changes can be visualized by transvaginal diagnostic ultrasound examination. The growth and decline of the endometrium can be measured and the texture changes can be described.

Besides the thickness and texture another intriguing aspect of the endometrium can be visualized by diagnostic ultrasound, namely endometrial wave-like movements in response to subendometrial muscular activity.

To describe endometrial activity in a non-invasive way, ultrasound techniques are used. Compared with previously used intrauterine pressure recordings, the main advantage of ultrasound is that it not only provides the ability to detect the movements of the endometrium but also (as opposed to pressure recordings) the direction of these "waves". Various recent ultrasound studies have confirmed the presence of peristaltic movements of the endometrium throughout the menstrual cycle. The description of the different types of movement, as well as the recording techniques, varied between the different studies.

To standardize the classification of the various endometrial activity patterns that can be visualised by ultrasound, a classification system has been introduced by IJland et al. (1). This classification system was developed after studying endometrial activity in spontaneous cycles. The movements of the endometrium were called "endometrial waves" and five different endometrial wave types were described. Unidirectional wave types, e.g. waves from the fundus of the uterus towards the cervix ( $\mathrm{FC}$ waves) and waves from the cervix to the fundus (CF waves) were recorded. In addition to the unidirectional waves opposing waves (OPP), random waves $(\mathrm{R})$ and no 
activity (No Act) were described. Opposing waves are waves starting simultaneously at the cervix and at the fundus of the uterus. Random waves reflect endometrial activity starting at various foci of the uterine cavity.

The occurrence of the different wave types, in different phases of the menstrual cycle, suggests a role for endometrial activity in reproduction. Waves from fundus to cervix for example prevail in the beginning of the cycle and might play a role in cleaning the uterine cavity (1). Towards the periovulatory phase there is a switch from FC waves into CF waves. Waves from cervix to fundus are presumed to play a role in the transport of spermatozoa towards the fallopian tubes $(2,3)$. Opposing waves are mostly detected in the late follicular and the early luteal phase. These endometrial waves are presumed to restrict the fertilized ovum to the upper part of the uterine cavity and prevent it from being expelled (1). Overall, most endometrial activity is detected in the periovulatory phase.

Also the frequency of endometrial waves increases towards the middle of the cycle, only to decrease again after ovulation (1).

Although endometrial waves are visible in the endometrium during ultrasound observation, they result from active peristaltic movements of the subendometrial myometrium. Because of the absence of muscle tissue, the endometrium itself is not able to move. The surrounding myometrium consists of three layers. The outer layer is the stratum subserosum, which consists of a bundle of longitudinal muscle fibers. The middle layer, the stratum vasculare, consists of circular smooth muscle fibers. The inner layer is called the stratum submucosum and consists of longitudinal smooth muscle fibers. This innermost layer of the myometrium is responsible for the peristaltic movements of the endometrium.

The stratum submucosum exhibits a cyclic pattern of estrogens and progesterone receptor expression, comparable to the endometrium. The cyclic pattern of steroid receptor expression in this part of the endometrium presumes a role for estrogen and progesterone in the coordination of endometrial activity (4). Indeed this postulation is supported by previous study results. In the postmenopause little 
or no spontaneous endometrial wave-like activity is detected. However, after the administration of estrogens to postmenopausal women waves from fundus to cervix and waves from cervix to fundus start to reoccur. FC waves disappear after administering progesterone (5). Furthermore, increased overall endometrial activity is observed in ovulation induction cycles relative to spontaneous ovulatory cycles. This difference in endometrial activity is probably related to the higher steroid levels in stimulated cycles as compared to spontaneous cycles (6).

Endometrial wave-like activity is conceivably an important uterine factor in fertility. In spontaneous cycles a relation was found between overall dampening of activity and the subsequent occurrence of a pregnancy (7). An observational study in 22 IVF patients has shown that the persistence of FC waves until the day of hCG administration, i.e. a late switch of $\mathrm{FC}$ waves to $\mathrm{CF}$ waves, was associated with the occurrence of a pregnancy. The authors of this paper suggest that the persistence of FC waves until the day of hCG administration is supportive of a good quality embryo to implant (8).

In the past, endometrial wave-like activity has been suggested to be influenced by intra-uterine manipulation, as may occur for example in embryo transfer. Several authors described a change in endometrial activity after embryo transfer, especially after difficult transfers. This influence on the activity pattern might result in failure of embryo implantation due to expulsion of the embryo in the antegrade (embryo loss) or retrograde way (ectopic pregnancy) $(9,10)$. 
In this thesis we first wish to validate the importance of the previously described late wave direction switch, i.e. the persistence of FC waves until the day of hCG administration in IVF treatment. Because the original results were based on a small study group, we want to validate its findings and investigate whether the results are reproducible in a larger, independent study group.

The original endometrial wave classification system was developed after studying endometrial wave-like activity in spontaneous cycles. Subsequently, it was also used to describe endometrial activity in stimulation cycles. During intensive studying of endometrial wavelike activity in these cycles and growing experience, we have started to observe more complex activity patterns than the endometrial waves-types first described in the original endometrial wave classification system. Because all observed wave-types might be important on specific moments in the cycle, it became necessary to describe the endometrial wave activity pattern in more detail. Since describing endometrial activity is still a research procedure, inclusion and documentation of all wave activity variations is mandatory. By doing so we hope to gain adequate insight, and miss no important wave characteristics. We therefore intend to expand the existing endometrial wave classification system and develop a refined classification.

Since intra-uterine manipulation for example in embryo transfer (ET) and intra-uterine insemination (IUI), is presumed to induce contractions and thereby may decrease pregnancy chances, we wish to investigate the effect of intra-uterine manipulation on endometrial wave-like activity $(9,10)$. First we will describe a pilot study in IVF patients, before and after ET. Secondly, we will evaluate the effect of intra-uterine manipulation on the direction and frequency of endometrial activity in a larger study group.

In previous studies in an IVF population we paid much attention to the day of hCG administration, because important clinical decisions regarding administering or withholding hCG have to be made during that period in the IVF treatment cycle. In this thesis we wish to describe endometrial wave-like activity more extensively 
throughout an extended part of the IVF cycle and in a larger study group. We will describe endometrial activity by means of the refined endometrial wave classification system. The observed endometrial wave-like activity will be related to IVF outcome. Furthermore we will investigate the hypothesis that more coordinated endometrial activity (pure FC waves or CF waves) is beneficial to IVF outcome. We will study whether endometrial waves are suitable as an independent predictor of pregnancy in IVF cycles 


\section{References}

1. IJland, M.M., Evers, J.L.H., Dunselman, G.A.J., van Katwijk, C., Lo, C.R., Hoogland, H.J. (1996) Endometrial wavelike movements during the menstrual cycle. Fertil Steril 65, 746-749.

2. Abramowics, J.S. and Archer, D.F. (1990) Uterine endometrial peristalsis a transvaginal ultrasound study. Fertil Steril 54, 451-4.

3. Kunz, G. Beil, D., Deininger, H., Wildt, L., Leyendecker, G. (1996) The dynamics of rapid sperm transport through the female genital tract: evidence from vaginal sonography of uterine peristalsis and hysterosalpingography. Hum Reprod 11, 627-32.

4. Noe, M., Kunz, G., Herbertz, M., Mall, G., Leyendecker, G. (1999) The cyclic pattern of the immunocytochemical expression of oestrogen and progesterone receptors in human myometrial and endometrial layers: characterization of the endometrial-myometrial unit. Hum Reprod 14, 190-97.

5. IJland, M.M. (2000) Endometrial wavelike activity in the nonpregnant uterus. Thesis, Maastricht

6. IJland, M.M., Evers, J.L.H., Dunselman, G.A.J., Hoogland, H.J. (1998) Endometrial wavelike activity, endometrial thickness, and ultrasound texture in controlled ovarian hyperstimulation cycles. Fertit Steril 70, 279-83.

7. IJland, M.M., Evers, J.L.H., Dunselman, G.A.J., Volovics, L., Hoogland, H.J. (1997) Relation between endometrial wavelike activity and fecundability in spontaneous cycles. Fertil Steril 67, 492-96.

8. IJland, M.M., Hoogland, H.J., Dunselman, G.A.J., Lo, C.R., Evers, J.H.L. (1999) Endometrial wave direction switch and the outcome of in vitro fertilization. Fertil Steril 71, 476-81.

9. Lesny P, Killick SR, Telow RL, Robinson J, Maguiness SD. (1998) Embryo transfer- can we learn anything new from the observation of junctional zone contractions? Hum Reprod 13, 1540-46.

10. Mansour RT, Aboulgar MA. (2002) Optimizing the embryo transfer technique. Hum Reprod 17, 1149-1153. 


\section{2}

\section{Aims of this thesis}

1. To validate our previous proposal that the persistence of waves from fundus to cervix until the day of hCG administration is associated with a favourable pregnancy prognosis.

2. To study endometrial wave-like activity intensively in order to establish a more detailed endometrial wave classification system.

3. To study the influence of intra-uterine manipulation on endometrial wave-like activity.

4. To analyze various characteristics of endometrial activity for their ability to predict the outcome of IVF treatment. 


\section{3 \\ Outline of the thesis}

In Chapter 2 an overview will be given of the literature regarding endometrial wave-like activity published so far, with attention for the different methods of recording and with a description of this activity and its presumed role in reproduction.

In Chapter 3 we will describe a validation study in 90 IVF patients in which we will investigate whether the persistence of endometrial waves from fundus to cervix until the day of hCG administration is associated with a favourable pregnancy prognosis.

In Chapter 4 the detection of more complex endometrial activity patterns will be described and translated in a more refined endometrial wave pattern classification system.

In Chapter 5 the effect of intra-uterine manipulation on endometrial wave-like activity will be evaluated. First a pilot study will be described in which the influence of intrauterine manipulation on the direction of endometrial waves will be investigated in 15 IVF patients. Secondly, the effect of intrauterine insemination (IUI) on the direction and frequency of endometrial wave-like activity will be studied in 36 IUI patients.

In Chapter 6 the association between several aspects of endometrial wave-like activity during the IVF cycle and the occurrence of pregnancy will be evaluated in 132 IVF cycles, and the clinical significance of endometrial waves in assisted reproduction will be discussed.

Finally, in Chapter 7 all findings will be summarized and discussed in relation to clinical practice and ideas will be developed on possible directions of future research. 
Chapter 2

in the non

$\stackrel{1}{9}$

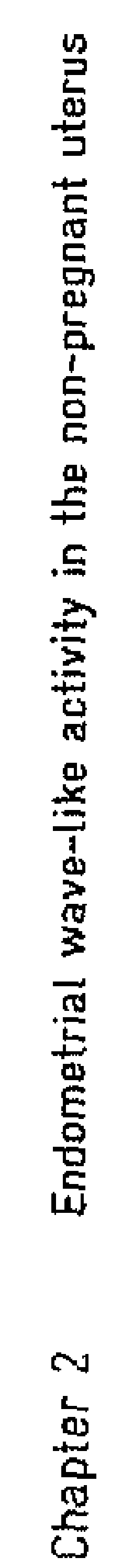




\section{Endometrial}

wave-like activity

-pregnant uterus 


\section{Abstract}

The non-pregnant uterus shows wave-like activity throughout the menstrual cycle. This uterine activity was first detected using intrauterine pressure recordings. The use of ultrasound has made it possible to study the movements of the uterus in a non-invasive way. Throughout the menstrual cycle several wavelike activity patterns have been described. The pattern of these endometrial waves changes throughout the menstrual cycle and is governed by steroid hormones. An adequate wave pattern seems to be related to successful reproduction in spontaneous cycles and assisted reproduction.

Further insight in the phenomenon of endometrial wave-like activity might offer an opportunity to correct abnormal wave patterns and thereby improve pregnancy rates.

Key words: endometrial waves / endometrial wave classification system / uterine contractions / transvaginal ultrasound / non-pregnant uterus 


\section{Introduction}

The non-pregnant uterus is not a quiescent organ. Its contractility has been described with the help of various methods. One of the first scientific papers on this subject was published in 1937 by Dickinson, who described the possibility to register uterine contractions by bimanual palpation (Dickinson, 1937).

Contractions and their characteristics, such as frequency, amplitude and basal pressure have been examined for the various phases of the menstrual cycle with the aid of intrauterine pressure transducers. Ultrasound has made it possible to study various aspects of uterine activity in a non-invasive way, by visualization of endometrial wavelike activity resulting from sequential segmental contractions in the subendometrial myometrium.

\section{Intrauterine pressure recordings}

Heinricius (1889) was the first to describe a method to record activity in the non-pregnant uterus with a balloon system. Several other authors used closed-tip intra-uterine catheters to measure uterine activity (Knaus, 1933; Moir, 1944; Csapo and Pino-Dantas, 1966). The results of the various studies applying this method were highly variable, mostly because of calibration problems due to variations in the size of the balloons, the volume of fluid introduced in the balloons, and the amount of pressure in the balloons at the onset of the recording period. The large volume of the balloon also acted as a potential uterine irritant.

The intra-uterine open-tip catheter, which was introduced by Hendricks (1964), theoretically affected the contractility of the uterus less than the closed catheters. Almost all authors who studied uterine contractility by this method gave similar qualitative assessments of the different contraction types throughout the cycle. During menstruation, regular labour-like contractions with a high intensity, high amplitude, low frequency and low basal pressure were described. In the proliferative phase, the pressure and frequency increased while amplitude and intensity decreased. In the peri-ovulatory phase the 
intensity was found to be low and the frequency high, while at ovulation, small, high-frequency contractions with high pressure were seen. In the second half of the cycle, towards menstruation, the intensity and amplitude increased and the frequency decreased (Hendricks, 1965; Hendricks, 1966; Cibils, 1967; Bengtsson, 1968; Eskes, 1969; Braaksma, 1970; Yoshida and Hendricks, 1970; Eskes et al., 1970; Hein, 1972). The absolute values measured by the various investigators however often differed. (Table 1)

\section{Ultrasound studies}

Since 1984, when Birnholz first used the transabdominal ultrasound technique to study movements in the non-pregnant uterus, ultrasound has been used to study uterine activity in a noninvasive way.

Intra-uterine pressure recordings provide information about frequency, amplitude and basal pressure tone. Ultrasound can also record contraction frequency, but its major asset is that it adds another dimension to the recordings, namely direction. This allows observation of the contractions that travel through the uterus in waves to be made, and their direction, frequency and velocity to be ascertained. It has been suggested recently that ultrasound is as effective as intra-uterine pressure recordings for measuring the frequency of uterine activity (Bulletti et al., 2000).

The composition of the patient groups used in ultrasound studies has varied widely, and the moments of measurement have not always been standardized (Table 2). In addition, the measuring methods used have also been variable. Some authors did not use taped video recordings and there has been no uniformity in recording and playback times (Table 2). Classification of the movements has also differed, in terms of the tissue movement and the direction (Table 3), as well as in the characteristics of the movements (Table 4).

The results of several ultrasound studies are summarized in table 5. In general, the ultrasound findings of the studies performed show movements from fundus to cervix during the early follicular phase. Movements from cervix to fundus have been described in the 
late follicular and peri-ovulatory phases, and most investigators describe an increased intensity of movements towards ovulation.

A classification system for describing the different activity types has also been proposed (IJland et al., 1996).

\section{Endometrial wave classification system}

One group (IJland et al., 1996) performed ultrasound examinations transvaginally with a $7.5 \mathrm{MHz}$ transducer. At each examination, between 3 and 15 minutes of video images were recorded of the uterus in the mid-sagittal plane. If no uterine activity was observed over a period of 3 to 5 minutes, the recording was discontinued. Off-line analysis was performed at high speed (four times normal) replay. This method seems comparable with those reported previously (de Vries et al., 1990; Lyons et al., 1991; Leyendecker et al., 1996), in which analysis was conducted at five times normal speed.

IJland's endometrial wave classification system distinguished five types of wave-like activity (Table 5). Waves from fundus to cervix dominated in the follicular phase and no fundus-to-cervix waves were seen after ovulation. A putative function of fundus-to-cervix waves is that of cleansing the uterine cavity and creating a barrier to ascending pathogens. Waves from cervix to fundus were recorded predominantly in the late follicular and the luteal phases. The cervix-to-fundus waves are assumed to promote sperm transport (Abramowics and Archer, 1990) and to restrict the implantation of the embryo to the upper uterine cavity (IJland et al., 1996). This phenomenon has also been described by others (Lyons et al., 1991; Kunz et al., 1996). The latter group mimicked sperm transport in the follicular phase by placement of labeled macrospheres of sperm size at the external cervical os. By serial hysterosalpingoscintigraphy it was shown that sperm reach the uterine cavity within minutes. The proportion of macrospheres entering the tubes is highest during the late follicular phase, when there is a maximum frequency and intensity of endometrial waves. The transport of the macrospheres was preferably directed into the tube ipsilateral to the dominant follicle (Kunz et al., 1996). These authors hypothesized that the direction of the 
endometrial wave towards the ipsilateral tube might be controlled by a specific myometrial architecture in combination with a asymmetric distribution of myometrial estrogen receptors. Furthermore, human semen contains large amounts of prostaglandins which may also promote the phenomenon of directed endometrial waves and isthmic tubal relaxation (Coutinho and Maia, 1971)

Opposing waves, which were observed during the first days after ovulation, might help prepare the endometrium for successful nidation and assist in providing the pre-implantation embryo with nutrients and oxygen (IJland et al., 1996).

In spontaneous menstrual cycles and stimulation cycles wave frequency can be analysed according to the presence of unidirectional waves (fundus-to-cervix and cervix-to-fundus). There is an increase in the frequency of fundus-to-cervix waves from the mid-follicular to the late follicular phase, while the frequency of cervix-to-fundus waves also increases from the mid-follicular phase towards the early luteal phase (IJland et al., 1996; Kunz et al., 1996). After ovulation, there is a reduction in the frequency of contractions, which might optimize the contact between the blastocyst and the endometrium to facilitate implantation (Fanchin et al., 1998, 2001). Kunz and collegues reported that during the luteal phase, the upper fundal part of the uterus shows a relative quiescence facilitating embryo implantation (Kunz et al., 2000b).

Wave velocity can be calculated for the unidirectional wave types. There is a trend towards increasing wave velocity in fundusto-cervix waves from the mid-follicular to the late follicular phase (IJland et al., 1997). Cervix-to-fundus waves seem to attain their highest velocity in the peri-ovulatory phase, underlining their putative role in rapid sperm transport, and these findings corroborate the results of other studies (Abramowics and Archer, 1990; Lyons et al., 1991). Because of the low inter-observer reproducibility and the complexity of measurements, the wave velocity measurements do as yet not appear to be appropriate for clinical application (IJland et al., 1997). 


\section{Endometrial waves and fecundability}

The contractility pattern in the non-pregnant uterus appears to play a role in the reproductive process. In spontaneous cycles, the endometrial wave type is related to fecundability (IJland et al., 1997). Conception cycles show a predominance of waves from cervix-tofundus in the peri-ovulatory phase, whereas waves from fundus to cervix are seen only during the late follicular phase and have never been detected after ovulation (IJland et al., 1997, Fanchin et al., 1998). Conception cycles show an overall dampening of endometrial wave activity during the consecutive phases of the cycle. Both dampening of activity and fine-tuning of the activity patterns at midcycle appear to be prerequisites for successful embryo implantation (Fanchin et al., 1998).

The endometrial wave pattern is also related to the occurrence of pregnancy in IVF cycles (IJland et al., 1999). The relative distribution of the different endometrial wave types in the stimulation period showed more fundus-to-cervix waves in conception cycles than in non-conception cycles. After administration of hCG, fundusto-cervix waves were no longer detected in either group. Most of the IVF cycles also showed a switch from fundus-to-cervix to cervix-tofundus waves, referred to as the wave direction switch (WDS). A premature switch from fundus-to-cervix to cervix-to-fundus waves, that is an early wave direction switch, is associated with a reduced pregnancy prognosis $(29 \%)$, while a late WDS is accompanied by a very favourable prognosis of pregnancy $(88 \%)$. The persistence of fundus-to-cervix waves until the day of hCG administration appears to help a good quality embryo to implant (IJland et al., 1999).

As was the case in controlled ovarian stimulation (COS) cycles, one group (IJland et al., 1998) showed that endometrial wave activity was more pronounced in IVF cycles. A statistically significant difference was found in wave frequency, which was higher in IVF cycles than in spontaneous cycles (Abramowics and Archer, 1990; IJland et al., 1999). Although the latter group could not find any relationship between the frequency of endometrial waves and the occurrence of pregnancy in IVF cycles, others (Fanchin et al.,1998b, 2001b) demonstrated a negative correlation between the frequency 
of endometrial waves on the day of embryo transfer and pregnancy outcome. High-frequency endometrial waves on the day of embryo transfer seem to affect IVF-embryo transfer outcome in a negative manner, perhaps by expelling embryos from the uterine cavity.

\section{Effect of steroid hormones on endometrial waves}

The cycle-dependent pattern of endometrial waves presumes a role for steroid hormones. First, endometrial activity is most pronounced in the peri-ovulatory phase, with high estrogen levels. Also, more endometrial activity is seen in IVF cycles and COS cycles with high estrogen levels, compared with spontaneous cycles. The wave direction switch during the course of the cycle appears to be governed by estrogens and progesterone.

To study this effect of steroids, spontaneous cycles were mimicked in post-menopausal women by giving the patients estradiol (days 1-28) and progesterone (days 14-28) (IJland et al., 2000). Ultrasound examinations have revealed that the prevalence of spontaneous endometrial wave-like activity is low or absent after menopause. Endometrial waves increase after estrogen administration, with waves from fundus to cervix being recorded in the estradiol-only phase of the cycle and vanishing immediately after the administration of progesterone. Waves from cervix to fundus are seen in both the estradiol-only phase and the estradiol-progesterone phase, with a maximum at the end of the estradiol-only phase.

Besides inducing a WDS, progesterone seems to have a relaxing effect in the non-pregnant uterus, as described by Fanchin and coworkers $(1998 \mathrm{~b}, 2000)$. The contention that the endometrial wavelike activity is predominantly governed by ovarian steroid hormones has also been supported by several others (Knaus, 1933; Bengtsson and Theobald, 1965; Oike et al., 1990; Bulletti et al., 1993; Batra, 1994; Kunz et al., 1998). 


\section{Anatomy}

The described endometrial waves are initiated in the subendometrial myometrium. This subendometrial myometrium or junctional zone can be identified using either magnetic resonance imaging (MRI) (Brosens, 1995) (Figure 1) or ultrasound (Kunz et al., 2000b). Like the endometrium, the subendometrial myometrium exhibits a cyclic pattern of estrogen receptor and progesterone receptor expression (Noe et al., 1999).

The outer layer of the uterus, the non-paramesonephric myometrium, is formed in a later embryological stage and seems to have functions that are predominantly confined to parturation (Noe $e t$ al., 1999). This outer portion of the uterine wall does not exhibit a cyclic pattern of estrogen and progesterone receptor expression (Noe et al., 1999).

\section{Conclusion}

The endometrium in the non-pregnant uterus shows distinct activity patterns throughout the menstrual cycle, which are called endometrial waves. These waves originate in the subendometrial myometrium and are influenced by steroids. The subendometrial activity might be initiated by pacemakers in the uterine muscle, providing the mechanical phenomena of endometrial waves. A relative quiescence of the uterus and an adequate wave pattern in certain phases of the cycle are related to successful reproduction. (IJland et al., 1997; Bulletti et al., 1997)

Uterine factors that have so far been implicated in decreased fertility are the presence of severe intra-uterine adhesions, deformity of the uterine cavity by fibroids, and congenital abnormality of uterus or cervix (Taylor and Collins, 1992). The existence of an abnormal wave pattern in a subfertile patient could be another uterine factor explaining subfertility, and this should be actively soughed in the future. Other examinations, such as endometrial biopsy, studying the texture of the endometrium by ultrasound, and hysteroscopy to reveal the presence of intra-uterine lesions, contribute little to the un- 
derstanding of the cause of otherwise unexplained infertility (Taylor and Collins, 1992).

Whilst in assisted reproduction there exists an important role for the pattern and frequency of endometrial waves, more insight is required into the phenomenon of endometrial waves and the factors which influence them, especially those of hormonal nature. This might provide an opportunity to correct an abnormal wave pattern or to modulate wave frequency to improve pregnancy rates, for example by exogenously changing hormone levels (Fanchin et al., 2001). Uterine contractility might also be stimulated by the use of prostaglandins (PG), for example the vaginal administration of PGE 1 analogue (misoprostol) in women undergoing intra-uterine insemination (Brown et al., 2001). If a premature wave direction switch should occur in IVF cycles, it could be hypothesized that it would perhaps be better to freeze the embryos and postpone the embryo transfer to another cycle.

Abnormal wave patterns or dysperistalsis have been described by two groups (Salamanca and Beltran, 1995; and Bulletti et al., 2002), both of which detected abnormal activity patterns in women with endometriosis. Others (Leyendecker et al., 1996, Kunz et al., 1996, Kissler et al., 2006) identified a relationship between this abnormal activity, endometriosis and impairment of directed sperm transport resulting in lower pregnancy rates. Furthermore, documentation of the endometrial wave patterns might contribute to an understanding of conditions such as dysmenorrhea, endometriosis and habitual abortion.

In the near future, MRI techniques might offer another means of detecting endometrial activity (Fujiwara et al., 2004, Togashi, 2007) and comparing the results with transvaginal ultrasound findings.

Further investigations are important to gain more insight into the phenomenon of endometrial waves. Moreover, improving the uniformity of recording these waves, as well as gathering details of their description and activity, might add to an understanding, diagnosis and treatment of unexplained fertility disorders. 


\section{References}

Abramowics, J.S. and Archer, D.F. (1990) Uterine endometrial peristalsis a transvaginal ultrasound study. Fertil. Steril., 54, 451-4.

Batra, S. (1994) Hormonal control of myometrial function. In Chard, T., Grudzinskas, J.G. (eds) The Uterus, Press Syndicate of the University of Cambridge, Cambridge, United Kingdom.

Bengtsson, L.P. (1968) The sponge catheter; a modification of the open end catheter for recording of myometrial activity in vivo. J. Reprod. Fertil, 16, 115.

Bengtsson, L.P. and Theobald, G.W. (1965) J. Physiology, (Londen), 178, 46.

Birnholz, J.C. (1984) Ultrasonic visuatisation of endometrial movements. Fertil. Steril., 41, 157-8.

Braaksma, J.T. (1970) Drukregistratie in de niet zwangere uterus in vivo. Thesis, Amsterdam.

Brosens, J.S. (1995) Uterine junctional zone : function and disease. Lancet, 346, $558-60$.

Brown, S.E., Toner, J.P., Schnorr, J.A., Williams, S.C., Gibbons, W.E., de Ziegler, D., Dehninger, $S$. (2001) Vaginal misoprostol enhances intrauterine insemination. Hum. Reprod., 16, 96-101.

Bulletti, C., Prefetto, R.A., Bazzocchi, G., Romero, R., Mimmi, P., Polli, V., Assuero Lanfranchi, G., Labate, A., Flamingi, C.(1993) Electromechanical activities of human uteri during extra-corporeal perfusion with ovarian steroids. Hum. Reprod, $8,1558-63$.

Bulletti, C., DeZiegler, D., Rossi, S., Polli, V., Massoneau, M., Rossi, E., Albonetti, A., Negrini, V., Flamigni, C. (1997) Abnormal uterine contractility in non-pregnant women. Ann. NY Acad. Sci., 828, 223-229.

Bulletti, C., DeZiegler, D., Polli, V., Diotallevi, L., Del Ferro, E., Flamgni, C. (2000) Uterine contractility during the menstrual cycle. Hum. Reprod., 15 (suppl. 1), $81-89$.

Bulletti, C., DeZiegler, D., Polli, V., Del Ferro, E., Palini, S., Flamingi, C. (2002) Characteristics of uterine contractility during menses in women with mild to moderate endometriosis. Fertil. Steril., 77, 1156-1161.

Chalubinski, K., Deutinger, J., Bernaschek, G. (1993) Vaginosonography for recording of cycle-related myometrial contractions. Fertil. Steril, 59, 225-28.

Cibils, L.A. (1967) Contractility of the nonpregnant uterus. Obstet. Gynecol., 30, 441-59.

Coutinho, E.M. and Maia, H.S. (1971) The contractile response of human uterus, fallopian tubes, and ovary to prostaglandins in vivo. Fertil. Steril., 22, 539-543 
Csapo, A.l., Pino-Pantas, C.R. (1966) The cyclic activity of the nonpregnant human uterus. A new method for recording intrauterine pressure. Fertil. Steril., 17, 34-8.

De Vries, K., Lyons, E.A., Ballard, G., Levi, C.S., Lindsay, D. (1990) Contractions of the inner third of the myometrium. Am. J. Obstet. Gynecol., 162, 679-82.

Dickinson, R.L. (1937) The technic of timing human ovulation by palpable changes in ovary, tube and uterus. Am. J. Obstet. Gynecol., 33, 1027-33.

Eskes, T.K.A.B., Hein, P.R., Kars-Villanueva, E.B., Braaksma, J.T, Janssens, J., Kollerie, A. (1969) The influence of steroids on the motility of the non-pregnant human uterus in vivo. Arch. Int. Pharmacodyn., 182, 409.

Eskes, T.K.A.B., Hein, P.R., Stolte, L.A.M., Kars-Villanueva, E.B., Crone, A., Braaksma, J.T., Janssens, J. (1970) Influence of dydrogestrone on the activity of the nonpregnant human uterus. Am. J. Obstet. Gynecol., 106, 1235-41.

Fanchin, R., Righini, C., Ayoubi, J.M. (1998) Uterine contractions at the time of embryo transfer: a hind implantation? Contracept. Fertil. Sex, 26(7-8), 498-505.

Fanchin, R., Rhigini, C., Olivennes, F., Taylor, S., de Ziegler, D., Frydman, R. (1998) Uterine contractions at the time of embryo transfer alter pregancy rates after in-vitro fertilization. Hum. Reprod., 13, 1968-74.

Fanchin, R., Ayoubi, J.M., Olivennes, F., Righini, F., de Ziegler, D., Frydman, R. (2000) Hormonal influence on the uterine contractility during ovarian stimulation. Hum. Reprod., 15 suppl. 1, 90-100.

Fanchin, R., Rhigini, C., DeZiegler, D., Olivennes, F., Ledee, N., Frydman, R. (2001) Effects of vaginal progesterone administration on uterine contractility at the time of embryo transfer. Fertil. Steril., 75(6), 1136-1140.

Fanchin, R., Ayoubi, J-M., Rhigini, C., Olivennes, F., Schonauer, L.M., Frydman, R. (2001) Uterine contractility decreases at the time of blastocyst transfers. Hum. Reprod., 16, 1115-1119.

Fujiwara, T., Togashi, K., Yamaoka, T., Nakai, A., Kido, A, Nishio, S., Yamamoto, T. (2004) Kinematics of the uterus: cine mode MR imaging. Radiographics, 24, 19.

Fukuda, M., Fufuda, K. (1994) Uterine endometrial cavity movements and cervical mucus. Hum. Reprod, 9, 1013-16.

Hendricks, C.H. (1964) A new technique for the study of motility in the nonpregnant human uterus. J. Obstet. Gynaecol. British Commonwealth, 71, 712-15.

Hendricks, C.H. (1965) Activity patterns in the nonpregnant human uterus. In Paul, W.M., Daniel, E.E., Kay, E.M., Monckton, G. The Muscle. Pergamon Press, New York.

Hendricks, C.H. (1966) Inherent motility patterns and response characteristics of the nonpregnant uterus. Am. J. Obstet. Gynecol., 96(6), 824-43. 
Hein, P.R. (1972) De contractiliteit van de uterus tijdens de menstruele cyclus en na toediening van geslachtshormonen. Thesis, Amsterdam.

Heinricius, G. (1889) En metod att grafiskt atergiva kontraktioner hos en icke gravid livmoder. Finsk Lakaresalist Handl, 31, 349.

IJland, M.M., Evers, J.L.H., Dunselman, G.A.J., van Katwijk, C., Lo, C.R., Hoogland, H.J. (1996) Endometrial wavelike movements during the menstrual cycle. Fertil. Steril, 65, 746-749.

IJland, M.M., Evers, J.L.H., Dunselman, G.A.J., Volovics, L., Hoogland, H.J. (1997) Relation between endometrial wavelike activity and fecundability in spontaneous cycles. Fertil. Steril., 67, 492-96.

IJland, M.M., Evers, J.L.H., Hoogland, H.J. (1997) Velocity of endometrial wavelike activity in spontaneous cycles. Fertil. Steril., 68, 72-75.

IJland, M.M., Evers, J.L.H., Dunselman, G.A.J., Hoogland, H.J. (1998) Endometrial wavelike activity, endometrial thickness, and ultrasound texture in controlled ovarian hyperstimulation cycles. Fertil. Steril., 70, 279-83.

IJland, M.M., Hoogland, H.J., Dunselman, G.A.J., Lo, C.R., Evers, J.H.L. (1999) Endometrial wave direction switch and the outcome of in vitro fertilization. Fertil. Steril., 71, 476-81.

IJland, M.M. (2000) Endometrial wavelike activity in the nonpregnant uterus. Thesis, Maastricht

Knaus, H. (1933) Zur technik der Registration von bewegungen der menschlichen gebärmutter. Zentrallblatt für gynakologie, 45, 2658-62.

Kunz, G. Beil, D., Deininger, H., Wildt, L., Leyendecker, G. (1996) The dynamics of rapid sperm transport through the female genital tract: evidence from vaginal sonography of uterine peristalsis and hysterosalpingography. Hum. Reprod., 11, 627-32.

Kissler, S., Hamscho, N., Zangos, S., Wiegratz, l., Schlichter, S., Menzel, C., Doebert, $N$. (2006) Uterotubal transport disorder in adenomyosis and endometriosis-a cause for infertility. BJOG, 113, 902-908.

Kunz, G., Noe, M., Herbertz, M., Leyendecker, G. (1998) Uterine peristalsis during the follicular phase of the menstrual cycle: effects of oestrogen, antioestrogen and oxytocin. Hum. Reprod. Update, 5, 647-54.

Kunz, G., Beil, D., Huppert, P., Leyendecker, G. (2000) Structural abnormalities of the uterine wall in women with endometriosis and infertility visualized by vaginal sonography and magnetic resonance imaging. Hum. Reprod., 15, 76-82

Kunz, G. (2000) In Filicori, M. (eds.) Endocrine Basis of Reproductive Function. Monduzzi 
Leyendeckers, G., Kunz, G., Widt, L., Beil, D., Deininger, H. (1996) Uterine hyperperistalsis and dysperistalsis as dysfunctions of the mechanism of rapid sperm transport in patients with endometriosis and infertility. Hum. Reprod., 11, $1542-51$

Lyons, E.A., Taylor, P.J., Zheng, X.H., Ballard, G., Clifford, C.S., Kredentser, J.V. (1991) Characterization of subendometrial myometrial contractions troughout the menstrual cycle in normal fertile women. Fertil. Steril., 55, 771-4.

Moir, J.C. (1944) The effect of posterior lobe pituitary gland fractions on the intact uterus. Journal Obstetrics Gynaecology of the British Empire, 51, 181-97.

Noe, M., Kunz, G., Herbertz, M., Mall, G., Leyendecker, G. (1999) The cyclic pattern of the immunocytochemical expression of oestrogen and progesterone receptors in human myometrial and endometrial layers: characterization of the endometrialmyometrial unit. Hum. Reprod., 14, 190-97.

Oike, K., Ishihara, K., Kikuchi, s. (1990) A study on endometrial movement and serum hormonal level in connection with uterine contraction. Nippon Sanka Fujinka Gakkai Zasshi, 1, 86-92.

Salamanca, A., Beltran, E. (1995) Subendomtrial contractility in menstrual phase visualized by transvaginal sonography in patients with endometriosis. Fertil. Steril., 64, 193-95.

Taylor, P.J., Collins, J.A. (eds) (1992) Unexplained Infertility. Oxford University Press, Oxford, United Kingdom.

Togashi, K. (2007) Uterine contractility evaluated on cine magnetic resonance imaging. Ann. N.Y. Acad.Sci., 1101, 62-71.

Yoshida, T. and Hendricks, C.H. (1970) Resting pressure patterns in the nonpregnant human uterus. Am. J. Obstet. Gynecol., 108, 450-57. 


\section{Table 1.}

Results of intra-uterine pressure recordings, using open-tip catheter, in the non-pregnant uterus.

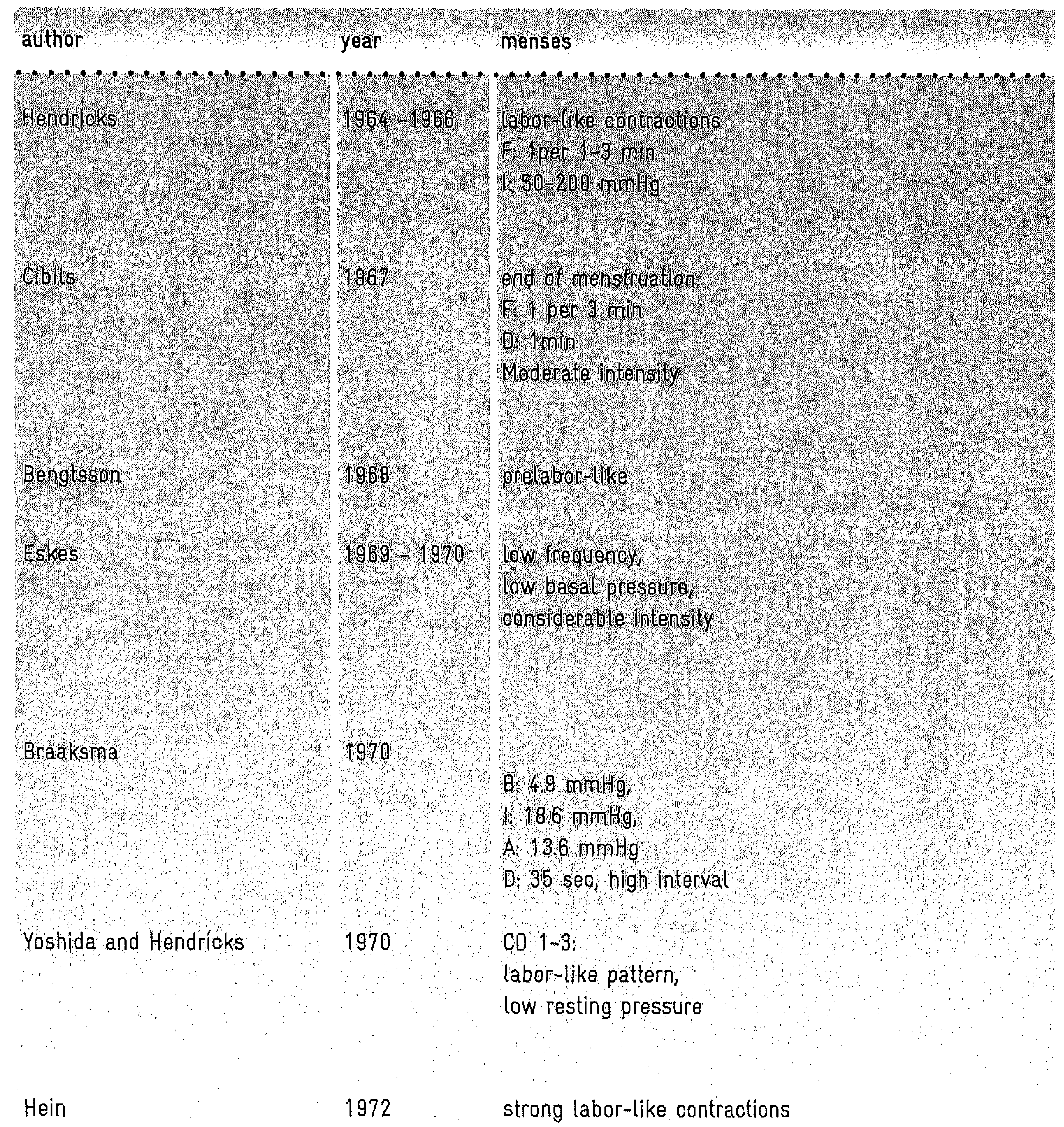

$F=$ frequency of contractions, $l=$ intensity of contractions, $D=$ duration of contractions,

$B=$ basal pressure of contractions, $A=$ amplitude of contractions, $C D=$ cycle day 


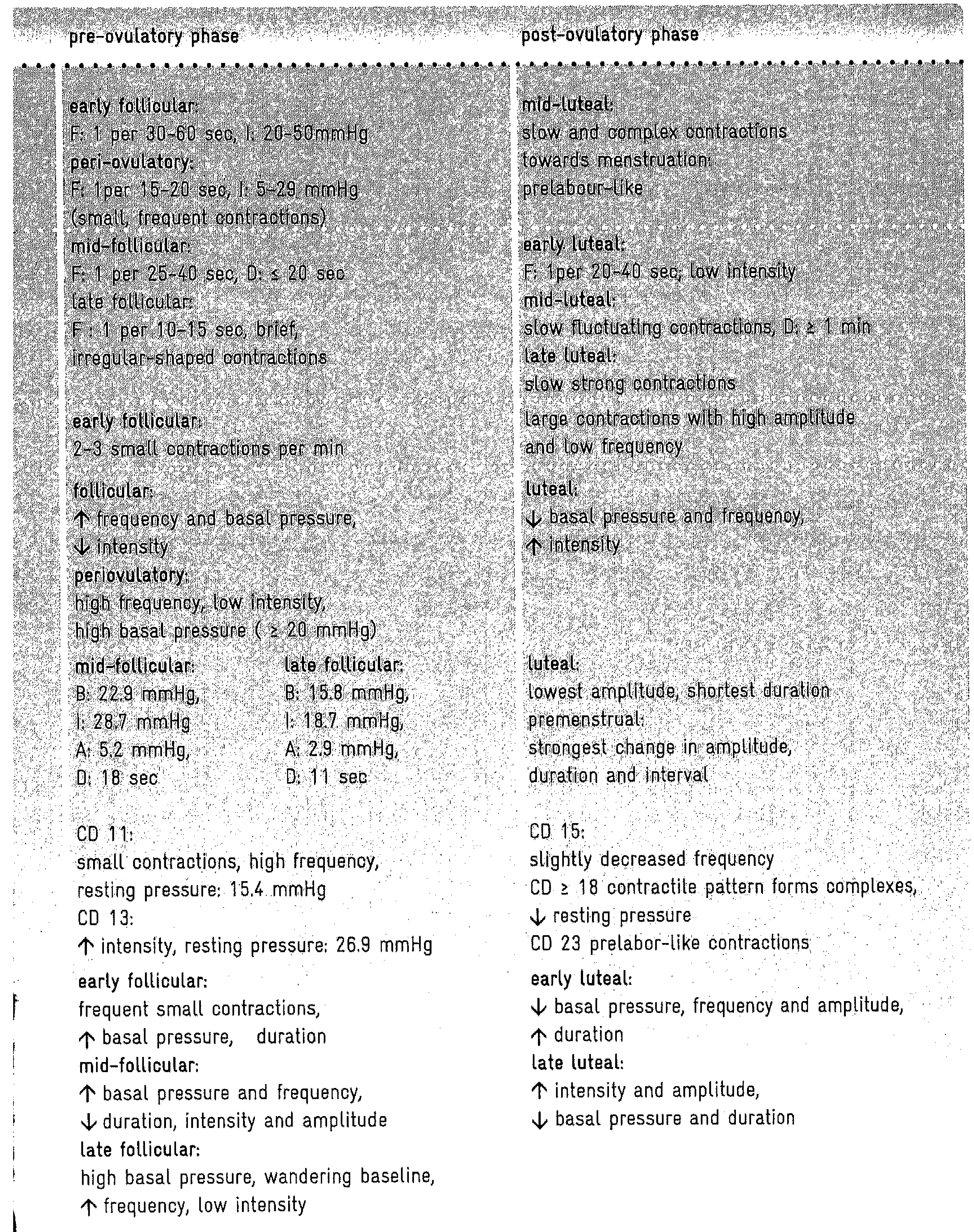




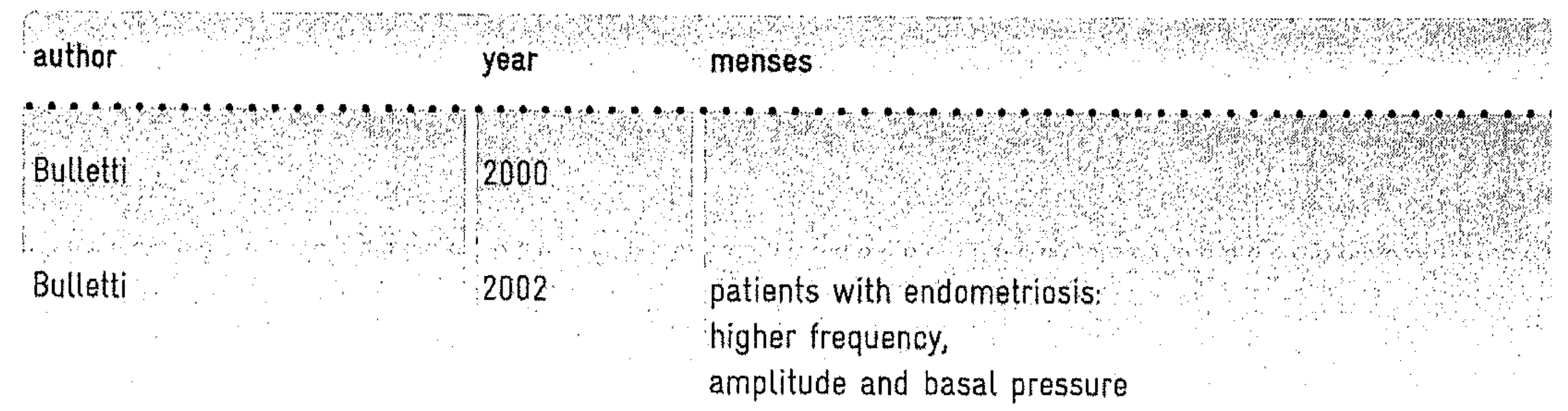

$F=$ frequency of contractions, $l=$ intensity of contractions, $D=$ duration of contractions,

$B=$ basal pressure of contractions, $A=$ amplitude of contractions, $C D=$ cycle day

\section{Table 2.}

Ultrasound studies of movements in the non-pregnant human uterus (adapted from IJland, 2000, with permission)

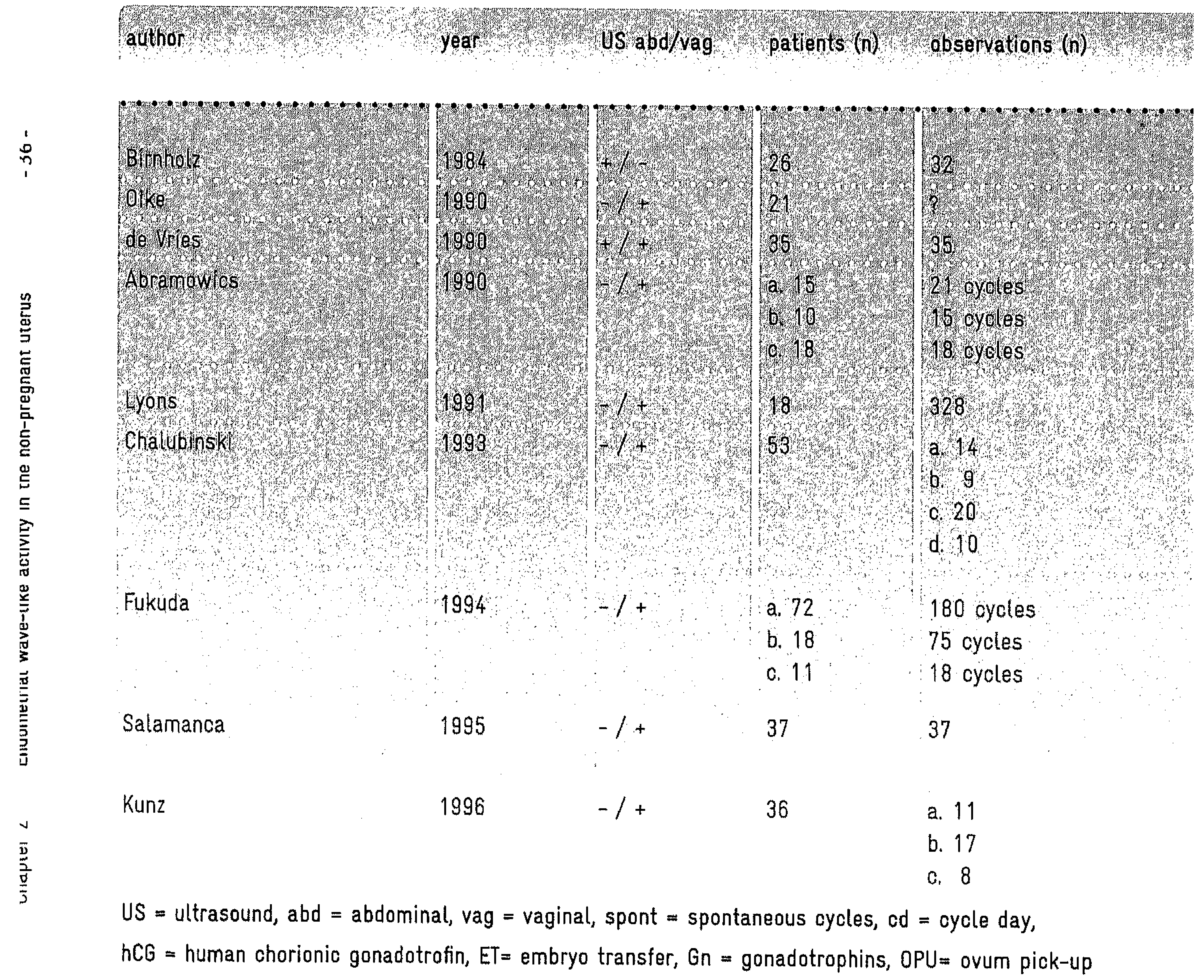



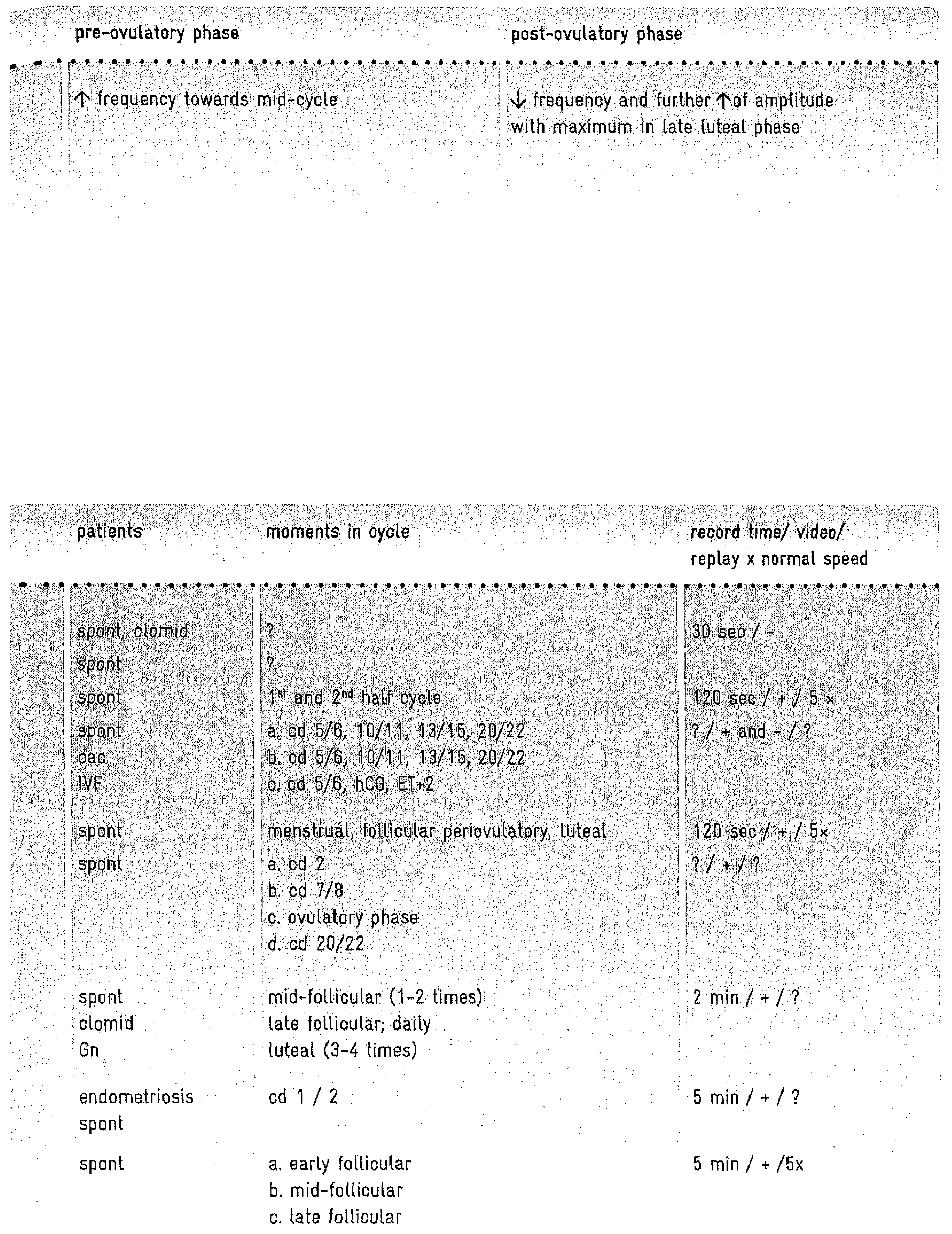


\begin{tabular}{|c|c|c|c|c|}
\hline author & year & $\begin{array}{l}\text { US } a b d / v a \\
g\end{array}$ & patients (n) & observations (n) \\
\hline$\cdots \cdots$ & $\cdots$ & 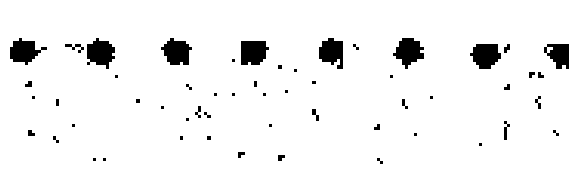 & $\cdots \cdot \cdots \cdot$ & $100+6$ \\
\hline \multirow[t]{2}{*}{ IJland } & $\begin{array}{l}1996 \\
1997 \\
1998\end{array}$ & $\begin{array}{l}-1+ \\
-1+ \\
-1+\end{array}$ & $\begin{array}{l}16 \\
47 \\
19\end{array}$ & $\begin{array}{l}23 \text { cyoles } \\
59 \text { cycles } \\
35 \text { cycles }\end{array}$ \\
\hline & 1999 & $-1+$ & 21 & 21 cycles \\
\hline \multirow[t]{2}{*}{ Fanchin } & 1998 & $-1+$ & 209 & 220 \\
\hline & 2001 & $-1+$ & 43 & 43 \\
\hline
\end{tabular}

$U S=$ ultrasound, $a b d=$ abdominal, vag = vaginal, spont $=$ spontaneous cycles, $c d=$ cycle day, $h C G=$ human chorionic gonadotrofin, $E T=$ embryo transfer, $G n=$ gonadotrophins, $O P U=$ ovum pick-up

\section{Table 3.}

Description of uterine movements in the non-pregnant human uterus by ultrasound (adapted from IJland, 2000, with permission)

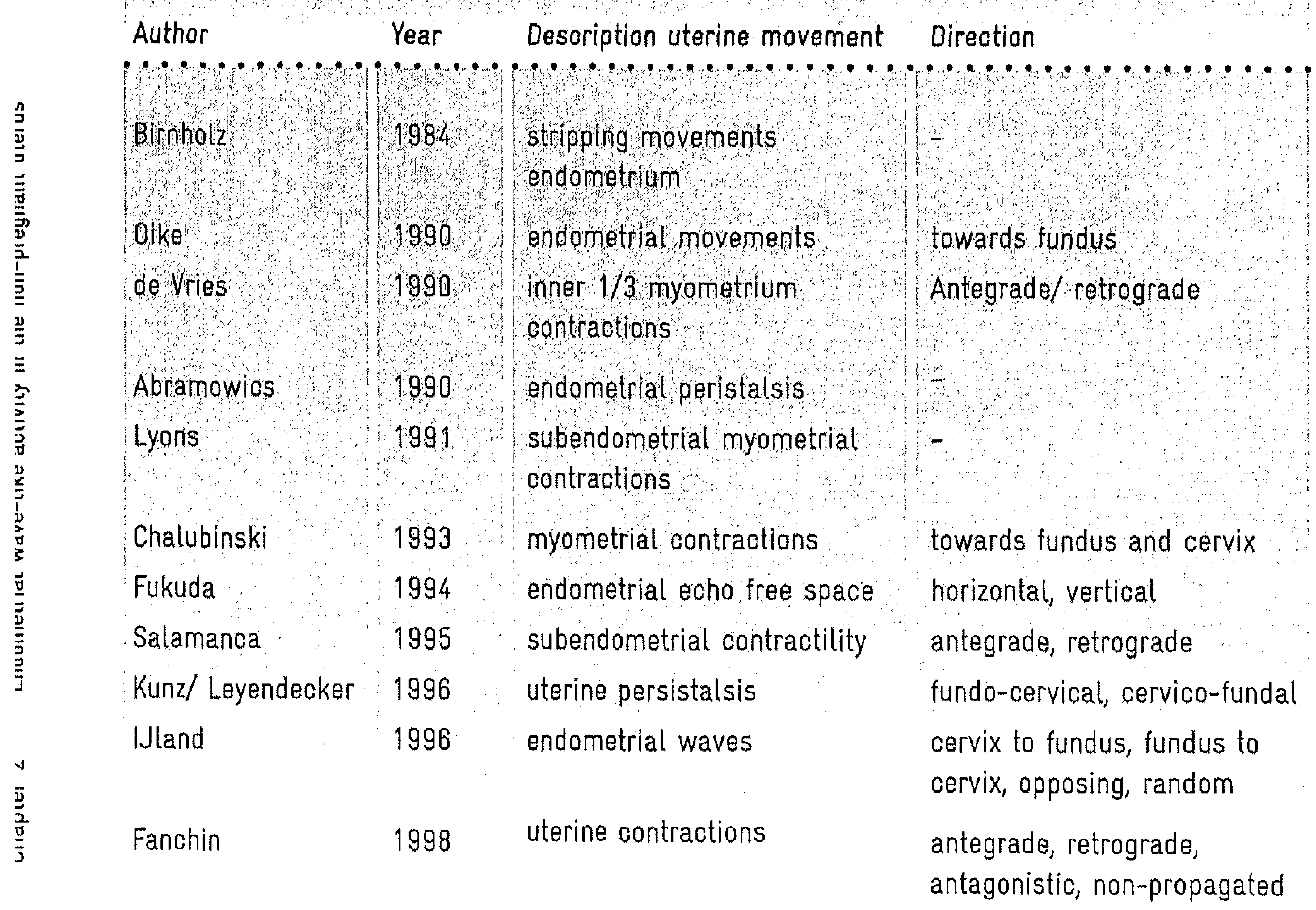


$\begin{aligned} \text { patients moments in cycle } & \begin{array}{l}\text { record time/ video/ } \\ \text { replay } x \text { normal speed }\end{array}\end{aligned}$

a. spont
$\begin{array}{ll}\text { b. spont } & a+b \text { early, mid-and late follicular, } \\ \text { c. Gn } & \text { c. start, } 2 x \text { stim period, } h C G, h C G+2, h C G+6, \\ \text { d. IVF } & \text { hCG } 9\end{array}$
d. start, $3 x$ stim period, hCG, OPU, ET, hCG 7

$3-15 \min / 1+14 x$

(d)

IVF

before ET

$5 \min /+/ 10 x$

IVF

$h C G, h C G+4, h C G+7$

$2 \min /-/ ?$

\section{Table 4.}

Aspects of movements in the non-pregnant human uterus studied by ultrasound (adapted from IJland, 2000, with permission)

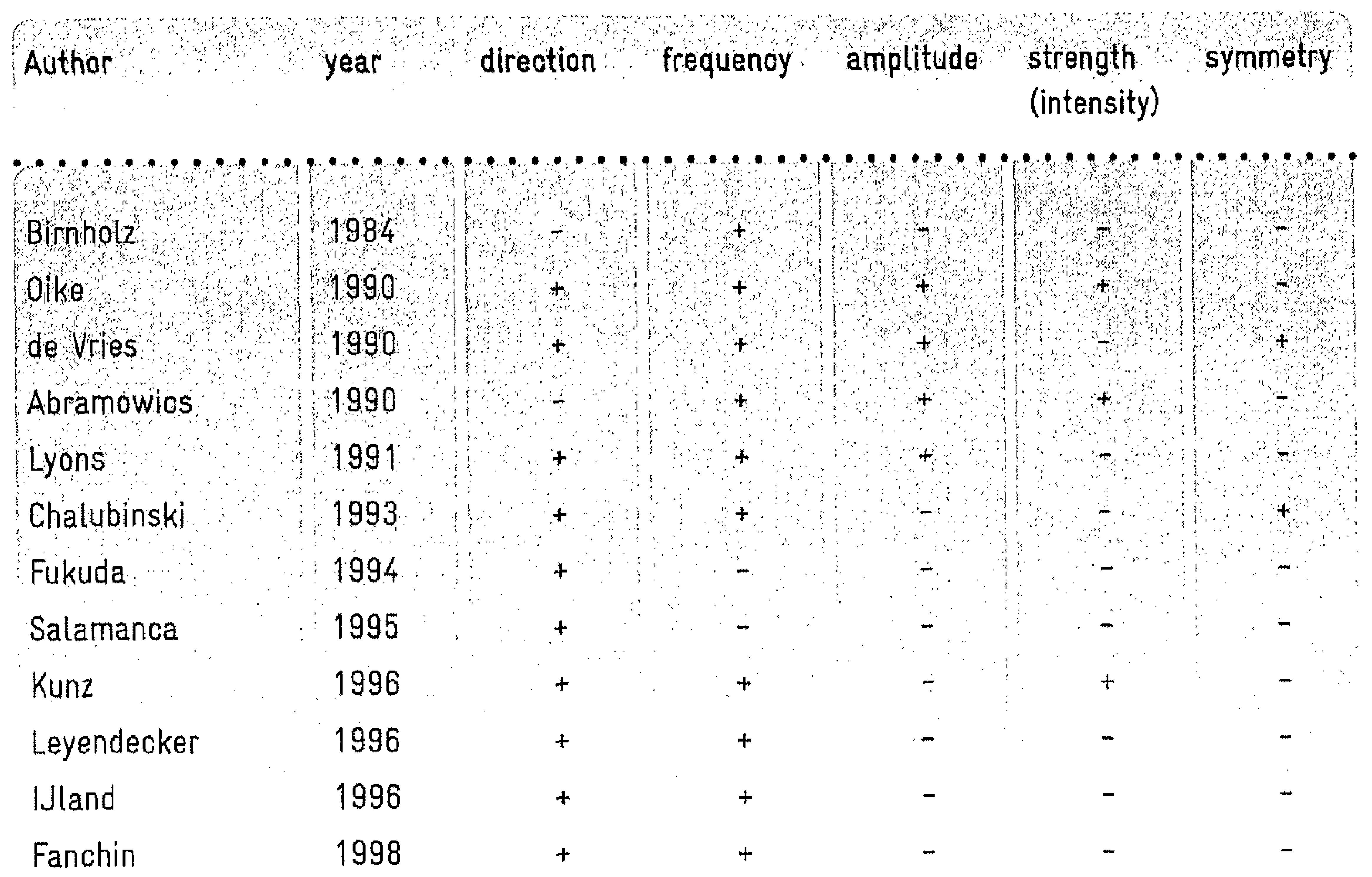




\section{Table 5 .}

Results ultrasound studies of mavements in the non-pregnant uterus (adapted from IJland, 2000, with permission)

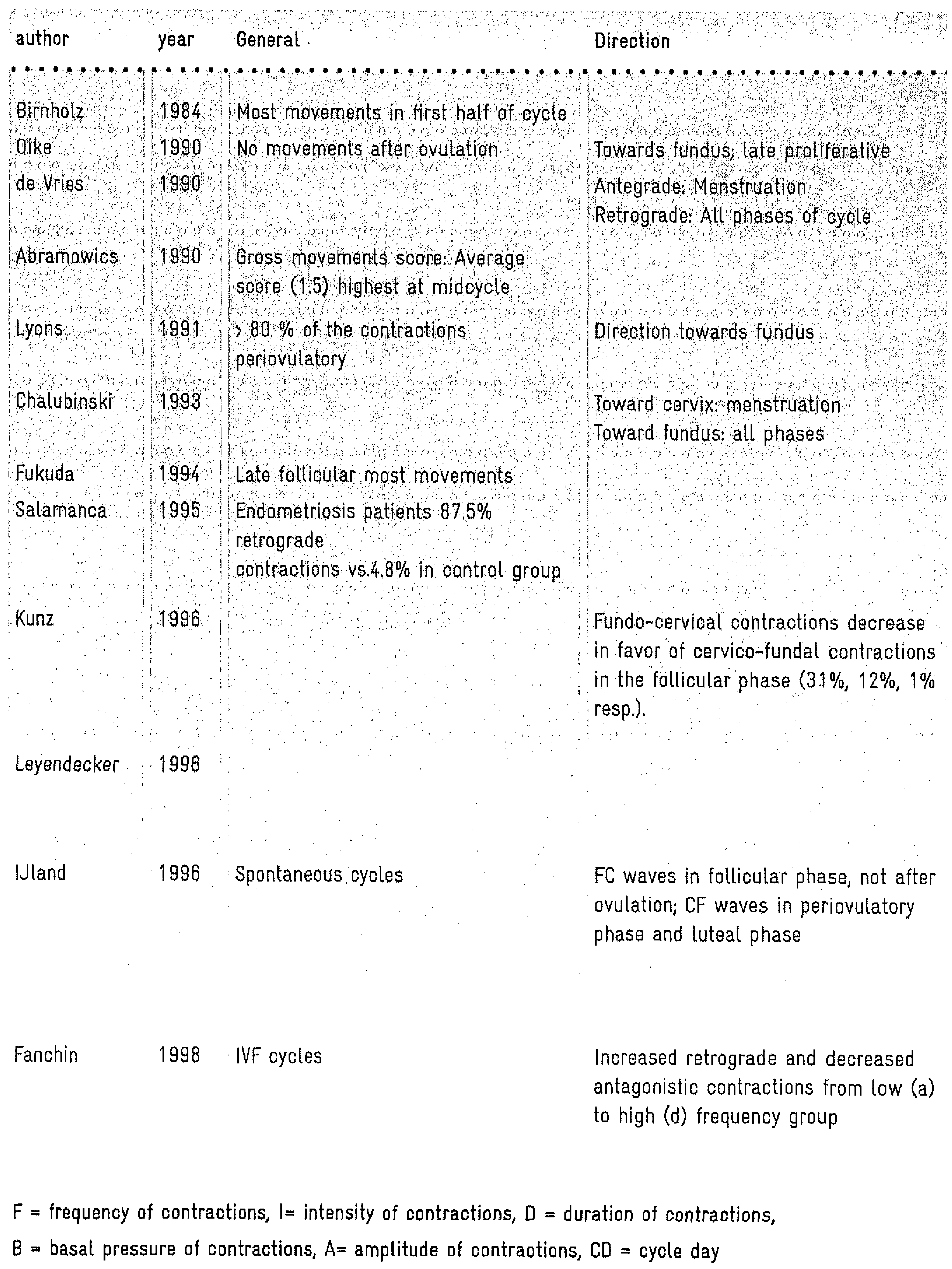




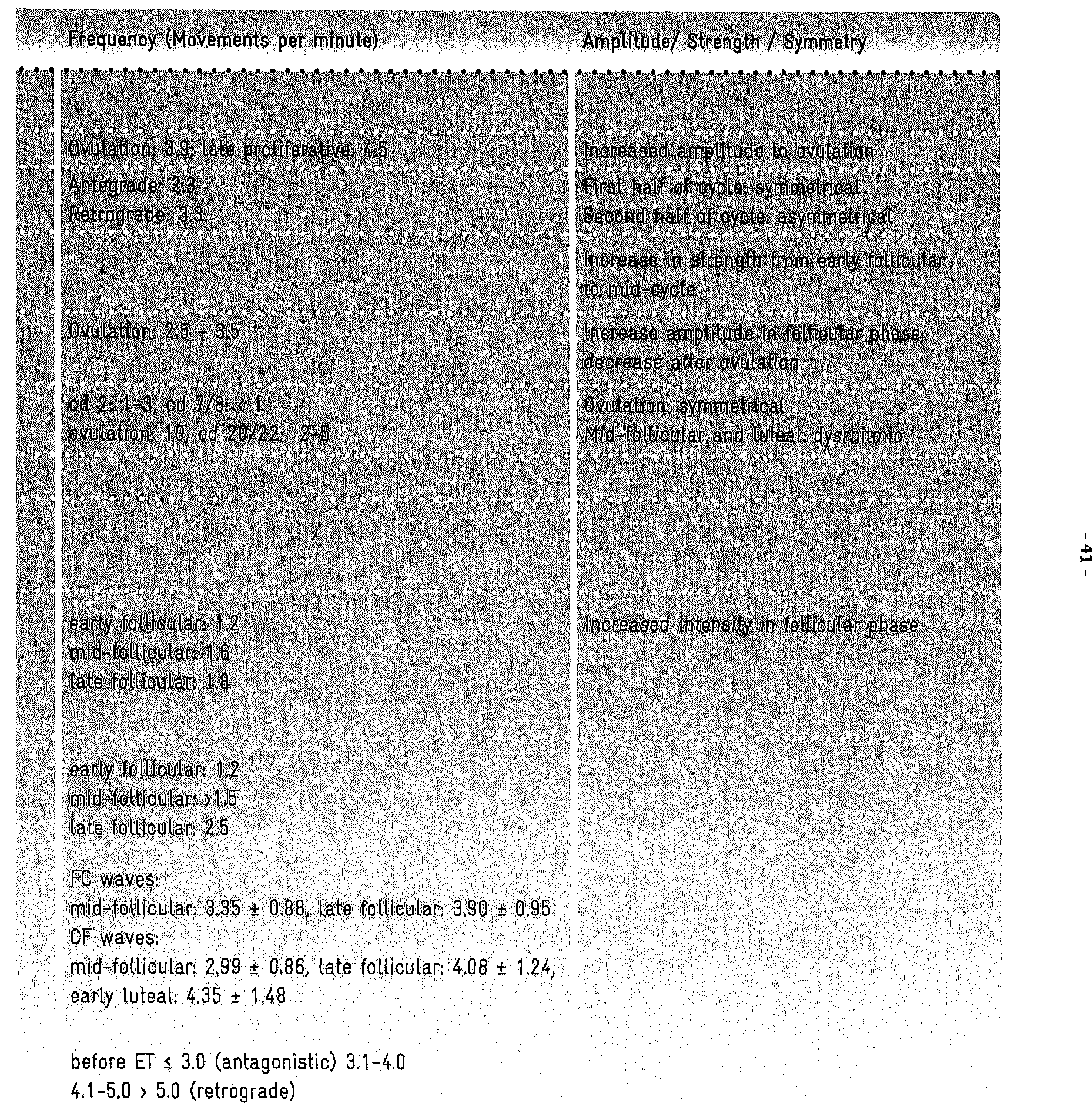




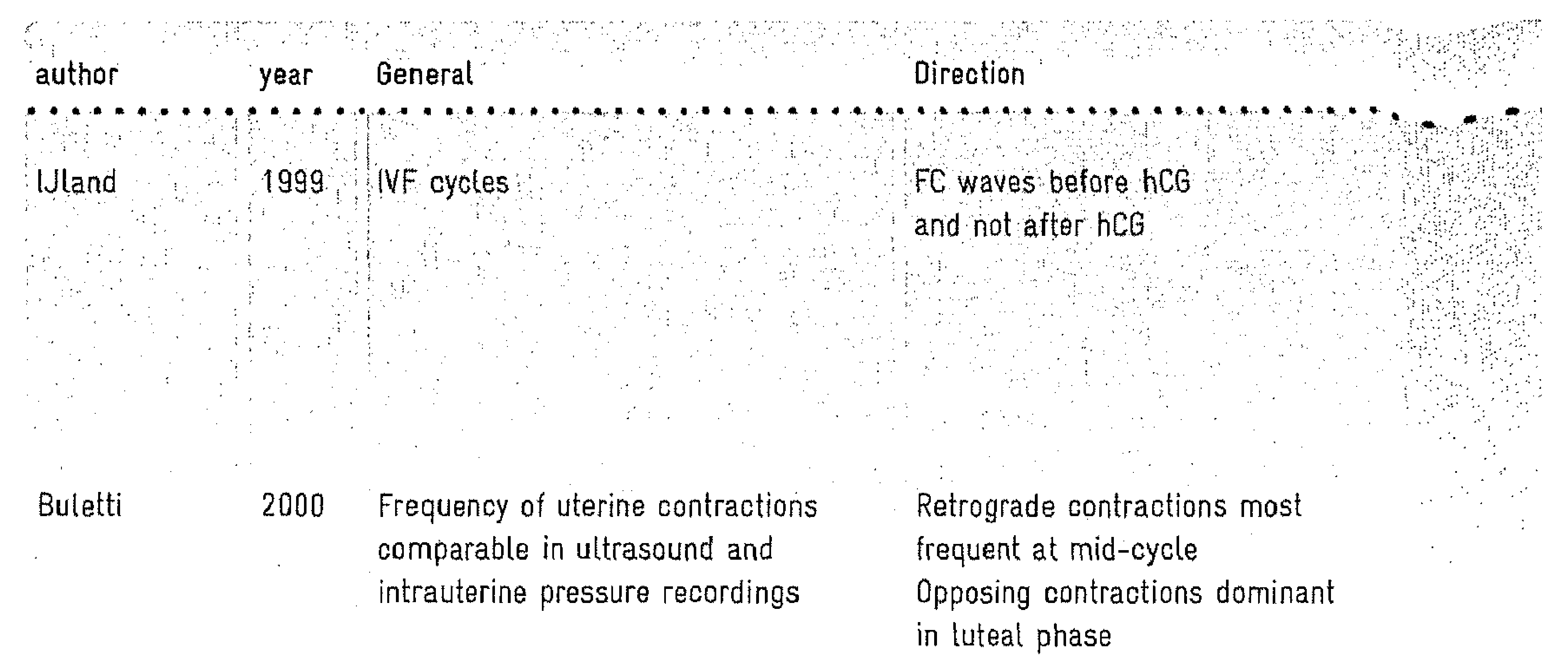

$F=$ frequency of contractions, $l=$ intensity of contractions, $D=$ duration of contractions,

$B=$ basal pressure of contractions, $A=$ amplitude of contractions, $C D=$ cycle day

\section{Table 6.}

Endometrial wave classification system (IJland et al., 1996)

fundus - to-cervix waves $(\mathrm{EC})$

cervix-to fundus waves (CF)

opposing waves (OPP)

random waves $(R)$

no activity waves from fundus to cervix

waves trom cervix to fundus

starting simultaneously at fundus and cervix

starting at various fooi

no endometrial activity visible 
Frequency (Movements per minute)

Amplitude/ Strength / Symmetry

\section{FC waves}

hCG $-6: 8.12 \pm 4.5$

hCo $715 \pm 5.2$

CF waves:

hCG-6: $7.11 \pm 4$

hCG: $9.4 \pm 5.7$

ET: $10.1 \pm 5.0$

Early and late luteal $1.8 \pm 1.9$ contractions/min

Early and late luteal $1.4 \pm 1.5$ contractions/min 


\section{Chapter 3}

\section{waves in in vitro \\ A validation}

\section{Capsule}

We performed a validation study to investigate whether the persistence of endometrial waves from fundus to cervix on the day of hCG administration is associated with a favourable pregnancy prognosis in IVF patients. 


\section{Endometrial \\ fertilization cycles \\ study}

Iris van Gestel, Marga M. IJland, Henk J. Hoogland, Johannes L. H. Evers Adapted from: Fertility and Sterility 2005; 83: 491-493 


\begin{abstract}
Objective: To validate the results of a previous study which showed a favourable pregnancy prognosis when endometrial waves from fundus to cervix ( $\mathrm{FC}$ ) persisted till the day of human chorionic gonadotropin (hCG) administration. To describe endometrial wavelike activity on the day of hCG administration and relate this activity to IVF outcome.

Design: Prospective ultrasound study

Setting: University hospital-based fertility clinic

Patient(s): Ninety patients undergoing IVF

Intervention(s): Ultrasound examination was performed on the day of hCG administration

Main outcome measure(s): Endometrial wave type, IVF outcome, top-quality embryo

Result(s): Embryo transfer was performed in 86 cycles. Twenty-seven patients showed FC waves on the day of hCG administration. Of these 11 conceived (41\%) compared to 19 of the $57(33 \%)$ in the group not showing FC waves. After transfer of at least one top-quality embryo 4 of the $6(67 \%)$ achieved pregnancy in the FC wave group, compared to 3 of the $13(23 \%)$ not showing FC waves.

Conclusion(s): We found no significant difference in the pregnancy outcome in IVF patients who have $F C$ waves on the day of hCG administration and patients who have no $\mathrm{FC}$ waves. Previous results could not be confirmed in this validation study.
\end{abstract}




\section{Introduction}

The non-pregnant uterus shows wave-like activity of the endometrium. These peristaltic movements are initiated in the subendometrial myometrium and can be easily visualised by transvaginal ultrasound. Observations in spontaneous (1) and stimulated (2) cycles revealed specific endometrial wave-like activity patterns throughout the menstrual cycle. Waves from fundus to cervix (FC waves) are predominantly seen in the follicular phase and disappear after ovulation or hCG administration. Waves from cervix to fundus (CF waves) prevail in the periovulatory fase (2).

A previous study of $22 \mathrm{IVF}$ cycles showed a relation between the direction of waves on the day of hCG administration and the pregnancy outcome (3). The persisting presence of FC waves was called a late wave direction switch (WDS) and was associated with a favourable pregnancy prognosis. A premature WDS was associated with a comparatively reduced pregnancy rate in that particular cycle.

We wished to validate the results of this small study in an independent larger group of patients.

\section{Materials and methods}

From October 2001 to October 2003, during three separate periods in which the main investigator was available, ultrasound observations were performed in 90 cycles in 90 women undergoing IVF. There were no exclusion criteria to participate in the study. All cycles were stimulated with recombinant FSH ( $r F S H$, Puregon; Organon, Oss, the Netherlands) in combination with intranasal administration of a GnRH analogue ( $\mathrm{GnRHa}$ ), nafareline (Synarel $200 \mu \mathrm{g} \mathrm{BID,}$ Roche, Mijdrecht, the Netherlands) or intramuscular triptoreline (Decapeptyl 0,1mg, once daily, Ferring, Hoofddorp, the Netherlands). Recombinant FSH was started after suppression of ovarian function with the GnRHa. The patients in this study received 100 E-250 E of $\mathrm{rFSH}$ as a single daily sc injection. 
Follicular growth was assessed by ultrasound. Human Chorionic Gonadotropin (hCG $5000 \mathrm{IU}$, Pregnyl, Organon) was administered as soon as at least five follicles reached a mean diameter of $\geq 18 \mathrm{~mm}$. E2 determinations are not performed routinely in our clinic. On the day of hCG administration, $\mathrm{rFSH}$ and $\mathrm{GnRHa}$ were discontinued.

Oocyte retrieval was performed under vaginal ultrasound guidance 34 hours after hCG administration. Embryos were transferred 2 to 3 days after insemination.

Ultrasound measurement of wave direction was performed on the day of hCG administration. The examination was performed transvaginally (7.5-MHz transducer) with the use of a real time scanner (Technos, Esaote-Pie Medical, Maastricht, the Netherlands). All ultrasound measurements were performed by a single observer (I.G.). Five to fifteen minutes of video footage was recorded at the midsagittal display of the uterus. If no uterine activity was observed during 5 minutes, the recording was discontinued. Off-line analysis was performed at high-speed ( 4 times) replay and focused on the presence (activity or no activity) and direction (wave type) of the endometrial wave-like activity. Endometrial wave-like activity was described by means of the wave classification system (2), which distinguishes five types of endometrial wave-like movements (Table 1). Cohen's Kappa statistics were calculated to assess agreement between observers and within observers. Kappa was 0.56 and 0.77 , respectively, indicating good agreement between and within observers (2).

Endometrial wave-like activity on the day of hCG administration was related to IVF outcome. Patients were divided into two groups: those with and those without FC waves on the day of hCG administration. In the previous article we suggested that the presence of FC waves during the late follicular phase is beneficial for a good quality embryo to implant (3). In order to exclude embryo factors as a cause of implantation failure as much as possible, cycles in which at least one top-quality embryo was transferred were analysed separately. Embryos were scored based on the number of pronuclei, the cleavage stage and the morphology of the embryo (4). Those patients who did not have an embryo for transfer $(n=4)$ were excluded from further analysis, since this precluded relating the wave pattern to the occurrence of pregnancy. 
A power calculation, based on our previous results, showed that we would need to include at least 80 patients in the present study to confirm our previous findings with alpha $=0.05$ and beta $=0.20$. Because of an expected drop out of about 10 percent we decided to include 90 patients.

\section{Results}

The age of the women ranged from 22 to 41 years (median 33). There were $64(71 \%)$ cases of primary subfertility and $26(29 \%)$ cases of secondary subfertility. Duration of subfertility varied from 1 to 14 years (median 4 years). Four different types of infertility were distinguished, namely, tubal pathology $(n=12)$, endometriosis $(n=2)$, male infertility $(n=53)$, and unexplained subfertility $(\mathrm{n}=23$ ). Duration of stimulation with $\mathrm{rFSH}$ ranged from 8 to 23 days (median 13). The number of retrieved oocytes ranged from 1 to 26 (median 7). Transfer of either 1 or 2 embryos, but never more, was performed in 86 women. Fertilisation failure occurred in 4 women. Thirty-one of the 86 women had a biochemical pregnancy, leading to $26(30 \%)$ ongoing pregnancies ( $>12$ weeks).

Eighty-three of the 86 women showed endometrial wave-like activity. In 2 patients the wave direction was not identifiable and thereby they were excluded from further analysis. Waves from cervix to fundus were the dominant wave type in 47 of 84 cycles. Waves from fundus to cervix were seen in 27 of 84 cycles. Opposing and random waves were rarely seen. These findings are consistent with previous studies $(3,5,6)$.

Twenty-seven of the 84 patients showed FC waves. Of these, 11 achieved a pregnancy (41\%), compared with 19 of the $57(33 \%)$ patients not showing FC waves on the day of hCG administration (Table 2). Although more patients became pregnant in the group showing FC waves, the difference is not statistically significant. Transfer of a top-quality embryo was performed in 19 of the 84 patients. Six of the 19 patients showed FC waves. Of these, 4 patients achieved pregnancy $(67 \%)$, compared with 3 of the $13(23 \%)$ patients not showing FC waves (NS, Table 3). 


\section{Discussion}

Endometrial wave-like activity is conceivably an important uterine factor in fertility. In a previous study we have shown that the persistence of FC waves until the day of $\mathrm{hCG}$ administration predicted a favorable pregnancy outcome. The wave direction recording seemed a fair predictor of failure of pregnancy (NPV, negative predictive value), but only a moderate predictor of pregnancy (PPV, positive predictive value). Our suggestion then was that the persistence of FC waves until the day of hCG administration is beneficial for a good quality embryo to implant. In the present study however we could not confirm the results in a larger study group. Although the IVF outcome was better in the group with FC waves, this was not statistically significant ( $\mathrm{p}=0.63$ ). Patients, in whom at least one top-quality embryo was transferred, had a better pregnancy chance $(67 \%)$ if FC waves were detected, compared to those without FC waves $(23 \%)$. Although this is in accordance with our theory about good quality embryos in relation to endometrial wave-like activity, the group is obviously too small to allow for drawing meaningful conclusions. Furthermore, embryo quality is a poorly defined entity that is subject to much controversy. It is tempting to suggest that if embryo quality can be defined better, the independent contribution of endometrial wave-like activity to conceiving via IVF may be investigated more reliably. The first figures from the present study of top-quality embryos suggest that in IVF, if corrected for embryo quality, the pattern of endometrial wave-like activity may be another determinant of successful implantation.

In an unselected group of IVF patients we could however not confirm the findings of our previous study. The present investigation shows the importance of validation studies. Exceptional incidental findings in a small study group, leading to a type-I error, should always be validated prospectively in an independent larger sample. 


\section{References}

1. IJland MM, Evers JLH, Dunselman GAJ, Hoogland HJ. Relation between endometrial wavelike activity and fecundability in spontaneous cycles. Fertil Steril 1997; 67: 492-6.

2. IJland MM, Evers JLH, Dunselman GAJ, van Katwijk C, Lo CR, Hoogland HJ Endometrial movements during the menstrual cycle. Fertil Steril 1996; 65: $746-9$.

3. IJland MM, Hoogland HJ, Dunselman GAJ, Lo CR, Evers JLH. Endometrial wave direction switch and the outcome of in vitro fertilization. Fertil Steril 1999; 71: 476-81.

4. Steer CV, Mills CL, Tan SL, Campbell S, Edwards RG. The cumulative embryo score: a predictive embryo scoring technique to select the optimal number of embryos to transfer in an in-vitro fertilization and embryo transfer programme. Hum Reprod 1992; 7: 117-9.

5. Kunz G, Beil D, Deininger $H$, Wildt $L$, Leyendecker $G$. The dynamics of rapid sperm transport through the female genital tract: evidence from vaginal sonography of uterine peristaisis and hysterosalpingography. Hum Reprod 1996; 11: 627-32.

6. Bulletti C, DeZiegler D, Polli V,Diotallevi L, Del Ferro E, Flamingi C. Uterine contractility during the menstrual cycle. Hum Reprod 2000; 15 (suppl. 1): 81-89. 


\section{Table 1.}

Endometrial wave classification system (2)

\begin{tabular}{|c|c|c|}
\hline Abbreviation & Wave direction & Description \\
\hline \multirow{3}{*}{\multicolumn{3}{|c|}{ 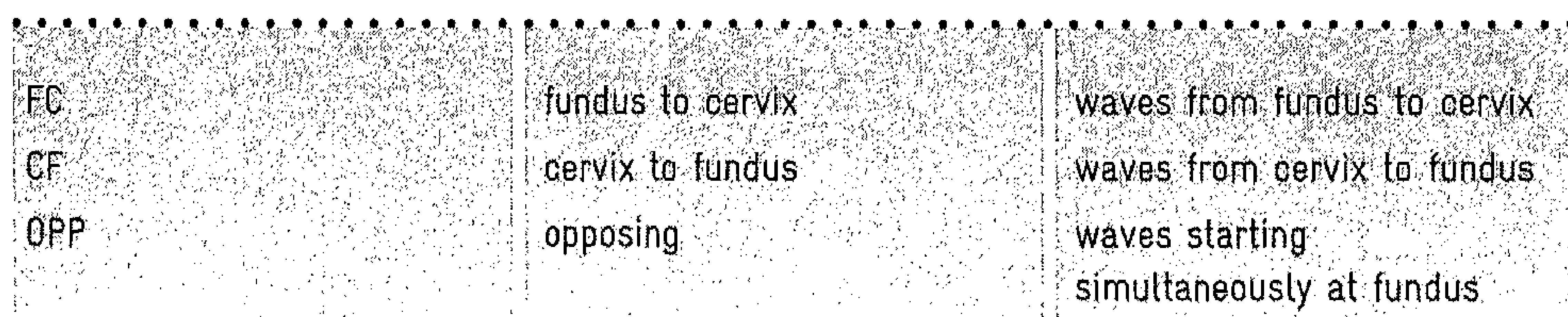 }} \\
\hline & & \\
\hline & & \\
\hline & & and cervix \\
\hline \multirow[t]{2}{*}{$R$} & random activity & activity starting at \\
\hline & & various foci \\
\hline
\end{tabular}

\section{Table 2.}

Recording of the wave direction on the day of hCG administration in relation to pregnancy

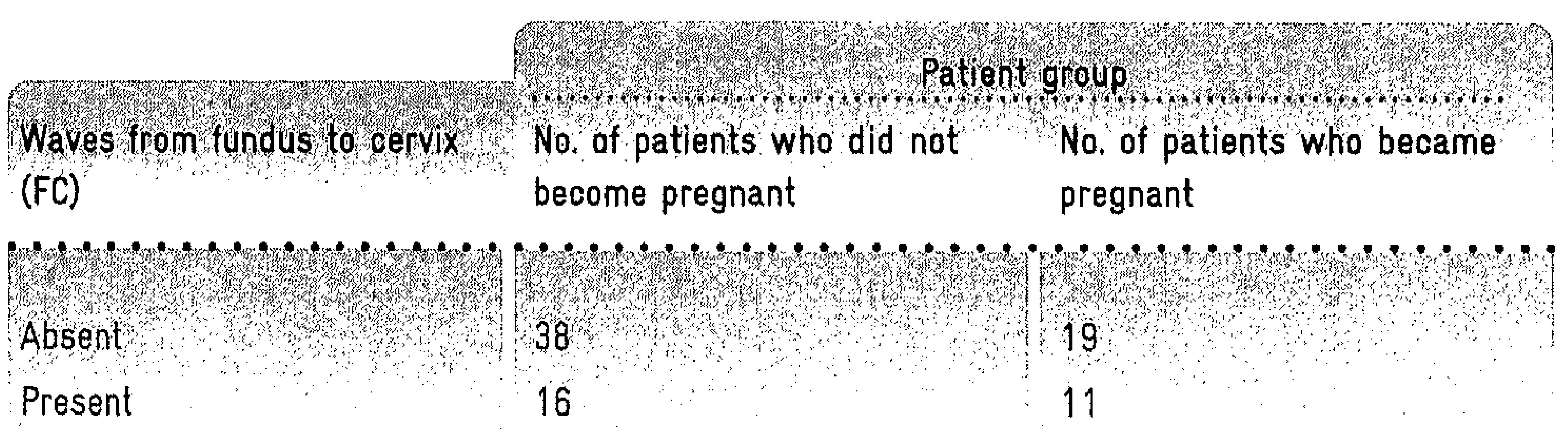

RR $1.1(95 \%$ C.I. $0.8-1.6), p=0.63$ 


\section{Table 3.}

Recording of the wave direction on the day of hCG administration in relation to pregnancy, in the top-quality embryo group.

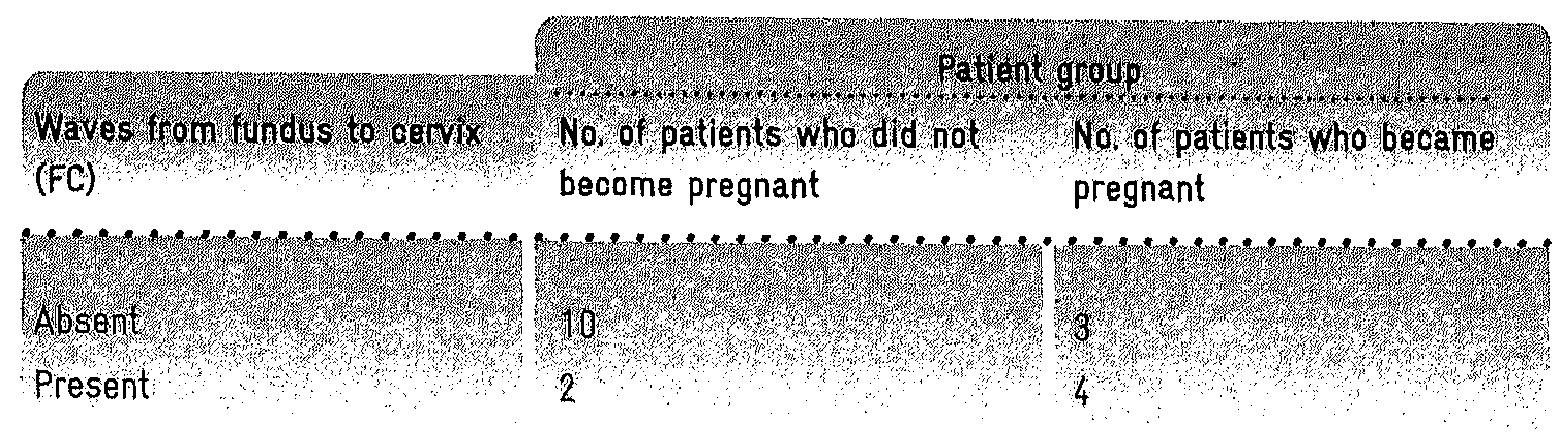

RR $1.9(95 \%$ C.I. $1.0-5.4), p$ (one-sided $)=0.09$ 


\section{Chapter 4 \\ Complex}

\section{wave-}

\section{Capsule:}

Descriptive study describing the detection of more complex endometrial activity patterns after intensive studying of ultrasound images from IVF-cycles, resulting in a refined endometrial classification system. 


\section{endometrial}

\section{patterns in IVF}

Iris van Gestel, Marga M. IJland, Johannes L.H. Evers, Henk J. Hoogland Fertility and Sterility 2007; 88: 612-615 


\begin{abstract}
Objective: To reanalyze ultrasound images from IVF-cycles with the aim to develop a refined endometrial wave classification system in order to be able to describe also the more complex endometrial wave patterns.

Design: Descriptive study.

Setting: University hospital-based fertility clinic.

Patient(s): Twenty-four patients undergoing IVF.

Intervention(s): Ultrasound examination was performed on the day of hCG administration.

Main outcome measure(s): endometrial wave type, intra- and interobserver agreement.

Result(s): Two new wave-types were added next to the endometrial wave types described in the original wave classification system, being recoiling CF waves and a standing wave. Furthermore an alternation between CF waves and $F C$ waves in the same fragment was described. The calculation of the interobserver and intraobserver agreement resulted in a kappa values reflecting strong agreement.

Conclusion(s): The refined endometrial wave classification system gives the opportunity to describe also the more complex wave types which can be detected in IVF-cycles on the day of hCG-administration.

Key words: Endometrial waves, endometrial wave classification system, uterine contractions.
\end{abstract}




\section{Introduction}

The non-pregnant uterus shows wave-like activity of the endometrium in spontaneous (1) and stimulated (2) cycles. These peristaltic movements are initiated in the subendometrial myometrium and can be visualised by transvaginal ultrasound.

Throughout the menstrual cycle specific endometrial wavelike activity patterns have been detected. Former observations of endometrial activity have resulted in an endometrial wave classification system (Table 1). Waves from fundus to cervix (FC waves) were predominantly seen in the follicular phase and disappeared after ovulation or hCG administration. Waves from cervix to fundus (CF waves) dominated the late follicular and the luteal phases (1).

FC waves seem to play a role in cleansing of the uterine cavity and creating a barrier to ascending pathogens. CF waves are assumed to promote sperm transport and restrict the implantation of the embryo to the upper uterine cavity (3). Endometrial wave-like activity is more pronounced in stimulated cycles compared to spontaneous cycles (2). An association between endometrial activity and fecundity has been suggested (4).

During intensive studying of endometrial wave-like activity and growing experience, we have observed more complex activity patterns than the patterns already described in the past. While using the original wave classification system it became increasingly clear that not all movements could be classified according to the original criteria. One reason for this was e.g. the occurrence of more than one wave type during the period under investigation.

Because certain combinations of wave-types might be important on specific moments in the cycle, it seems necessary to describe this endometrial wave activity pattern as a separate wave type in the endometrial wave classification system. The aim of the present study was to expand the existing endometrial wave classification system, to be able to describe endometrial activity more in detail.

We used digitally stored, standardized images from IVF-cycles on the day of hCG administration for further investigation, because endometrial activity is most pronounced in this period and this is the time that in the IVF clinic important clinical decisions have to be made. 


\section{Materials and methods}

In a previous study, video images were collected from 24 IVF cycles. All described cycles were stimulated using recombinant FSH (Gonal-F, Serono, Den Haag, the Netherlands) in combination with intranasal administration of a GnRH analogue, nafareline (Synarel $200 \mu \mathrm{g} 2 \mathrm{dd}$, Abbott, Mijdrecht, the Netherlands). All patients in this study used a fixed dose of two ampules of recombinant FSH (150 E) as a single subcutaneous injection. Human chorion gonadotropin (Profasi, 10.000 IU, Serono, Den Haag, the Netherlands) was administered as soon as at least five follicles reached a mean of $\geq 18 \mathrm{~mm}$. Duration of stimulation ranged from 8 to 12 days (5).

On the day of hCG administration endometrial activity was recorded of the uterus in the midsagittal plane, during 5-15 minutes (5). This method of recording is comparable to that of de Vries et al., Lyons et al. and Leyendecker et al. $(6,7,8)$. In the described study ultrasound recording of endometrial activity was performed during routine ultrasound measurement for IVF treatment (5).

Off-line analysis of the material was performed at high speed (4x) replay and focused on the direction of the endometrial waves. Wave types, according to the endometrial wave classification system, were noted and the dominant wave type was used for analysis (5). In line with other investigators we considered the unidirectional waves to be the most important wave-types (3).

In the present study the available video-material was transcribed from s-VHS tapes to mini DV tapes (HR DVS3EH, JVC, Japan). A representative fragment was selected (a fragment of about 3 minutes, the uterus properly scanned in the midsagittal plane, no artifacts). This fragment was digitized by means of Avid Xpress software (Avid Technology, Tewksbury, USA) and stored on an external hard drive (250 gigabyte Maxtor, Maxtor Corporate, California, USA).

Analysis of the digitized material was performed at high-speed replay (4 times). Three investigators ( $\mathrm{HH}, \mathrm{MIJ}, \mathrm{IG}$ ) subsequently described the material and focused on the direction of endometrial waves visible during these fragments. 
To describe the wave-like activity of the endometrium in more detail, the most experienced investigator $(\mathrm{HH})$ adjusted the generally used classification system in order to obtain more specific information of the visible endometrial activity (Table 2). The second and third investigator used this refined classification, independently, to qualify the endometrial activity. Inter- and intraobserver agreement was calculated.

Clinical applicability might be even more facilitated if the outcome of real time analysis of the endometrial waves is comparable to high-speed analysis. Therefore two investigators also performed a real time assessment of endometrial wave activity, and interobserver agreement were computed.

\section{Results}

On the day of hCG administration the following wave types of the endometrium were found, some of which might belong to the same spectrum of wave activity: waves from cervix to fundus $(\mathrm{CF})$, recoiling $\mathrm{CF}$ waves ( $\mathrm{CF}+$ recoiling), waves from fundus to cervix $(\mathrm{FC})$, a combination of CF- and FC-waves and, rarely, standing waves. (Table 3) So next to the previously described wave-types, two new wave-types were found, being recoiling $C F$ waves and a standing wave. Furthermore an alternation between $\mathrm{CF}$ waves and FC waves in the same fragment was detected.

The calculation of the interobserver agreement between the three different investigators resulted in a kappa value of 0.83 , reflecting strong agreement (Table 3). The intraobserver agreement within the three investigators was $0.91,0.78$ and 0.96 , also proving good to excellent agreement.

When comparing real time analysis with high speed analysis of endometrial activity only modest agreement was found (kappa 0.4, Table 4).

Patient demographic data and pregnancy results are described in the previous publication (5). 


\section{Discussion}

The direction of endometrial wave-like activity has been scored by means of the endometrium wave classification system in our previous studies. In those studies wave types were scored in video fragments with differing lengths $(1,2,4)$. For analysis in stimulated cycles only the dominant wave type was used $(2,4)$. Although there is little uniformity in the description of endometrial activity by several investigators so far, most investigators focused on the unidirectional endometrial wave types (3).

With growing experience in evaluating endometrial activity we observed more complex activity patterns than the wave-types already described. These activity patterns could not be classified according to the original wave classification system. To study wave-like activity more in detail we digitized a selection of video material of IVF patients on the day of hCG administration. The critical investigation of this material by three investigators independently, with good agreement (kappa 0.83 ), encourages us to suggest a revision of our previous endometrium wave classification system in which more complex wave types may be classified.

The combination of $\mathrm{CF}$ and $\mathrm{FC}$ waves, recoiling $\mathrm{CF}$ waves and a standing wave are the new components. The recoiling $\mathrm{CF}$ wave is a wave from cervix to fundus with a reflection of the wave towards the cervix after reaching the fundus of the uterine cavity. A standing wave pattern is not actually a wave; rather it is the pattern resulting from the presence of two or more waves of the same frequency with opposing motion. The new classification system gives the opportunity to describe in more detail the pattern of endometrial activity in that part of the cycle.

We have not tried to relate the newly described endometrial wave patterns to pregnancy outcome in this study group, because of the small number of patients. In a previous publication we have confirmed the importance of prospective validation of pregnancy data in relation to endometrial wave patterns (9).

We have only looked in more detail on the day of hCG administration in IVF cycles, therefore it is not clear whether the more complex activity patterns can only be detected in stimulated cycles. In 
future investigations we want to compare the findings of the present study to the findings at different moments in spontaneous and IVF cycles. By doing so we want to investigate whether the more complex endometrial activity patterns detected are a normal physiological pattern with a function in reproduction, or an artifact induced by the higher hormonal levels in stimulation cycles $(10,11)$.

To improve clinical applicability it is less time consuming to analyze endometrial activity at normal speed instead of high-speed replay. Inter- and intraobserver agreement however is very low in normal speed analysis. This finding is in agreement with other investigators of endometrial contractions, all in favor of high speed replay (3). The development of inboard software for ultrasound equipment is necessary for more efficient recording and analysis of endometrial activity. This will facilitate implementation of endometrial wave detection for clinical use.

In previous studies the endometrial wave classification system was used to describe the endometrial wave-like activity in spontaneous and stimulated cycles. This classification system gives no insight in the more complex activity patterns in the uterus. By intensive studying of the uterus to gain more insight in physiology of the uterus, we were able to develop a refined endometrial classification system. Although this system might seem more complex, the findings of three different investigators are comparable. The role of the newly described activity patterns in normal physiology and their relation to fecundity need to be elucidated. 


\section{References}

1. IJland MM, Evers JLH, Dunselman GAJ, van Katwijk C, Lo CR, Hoogland HJ Endometrial wavelike movements during the menstrual cycle. Fertil. Steril. 1996; 65: 746-49.

2. IJland MM, Evers JLH, Dunsleman GAJ, Hoogland HJ. Endometrial wavelike activity, endometrial thickness, and ultrasound texture in controlled ovarian hyperstimulation cycles. Fertil. Steril. 1998; 70: 279-83.

3. van Gestel I, IJland MM, Hoogland HJ, Evers JLH. Endometrial wave-like activity in the non-pregnant uterus. Hum Reprod Update 2003; 9:131-8.

4. IJland MM, Evers JLH, Dunselman GAJ, Volovics L, Hoogland HJ. Relation between endometrial wavelike activity and fecundability in spontaneous cycles. Fertil. Steril. 1997; 67: 492-96.

5. IJland MM, Hoogland HJ, Dunselman GA, Lo CR, Evers JLH. Endometrial wave direction switch and the outcome of in vitro fertilization. Fertil. Steril 1999; 71: 476-81.

6 De Vries K, Lyons EA, Ballard G, Levi CS, Lindsay D. Contractions of the inner third of the myometrium. Am J Obstet Gynecol.1990; 162: 679-82.

7. Lyons EA, Taylor PJ, Zheng XH, Ballard G, Clifford CS, Kredentser JV. Characterization of subendometrial myometrial contractions throughout the menstrual cycle in normal fertile women. Fertil. Steril. 1991; 55: 771-4.

8 Leyendecker $G$, Kunz $G$, Widt L, Beil D, Deininger $H$. Uterine hyperperistalsis and dysperistalsis as dysfunctions of the mechanisms of rapid sperm transport in patients with endometriosis and infertility. Hum Reprod. 1996; 11: $1542-51$.

9 van Gestel I, IJland MM, Hoogland HJ, Evers JLH. Endometrial waves in in vitro fertilization cycles: A validation study. Fertil. Steril. 2005; 83: 491-3.

10. Papanikolaou EG, Bourgain C, Kolibianakis E, Tournaye H, Devroey, P. Steroid receptor expression in late folliculair phase endometrium in $\mathrm{GnRH}$ antagonist IVF cycles is already altered, indicating initiation of early transformation in the absence of secretory changes. Hum. Reprod. 2005; 20: 1541-47.

11. Bourgain $C$, Devroey $P$. The endometrium in stimutated cycles for IVF. Hum Reprod. Update. 2003; 9: 515-22. 


\section{Table 1.}

The original wave classification system (1)

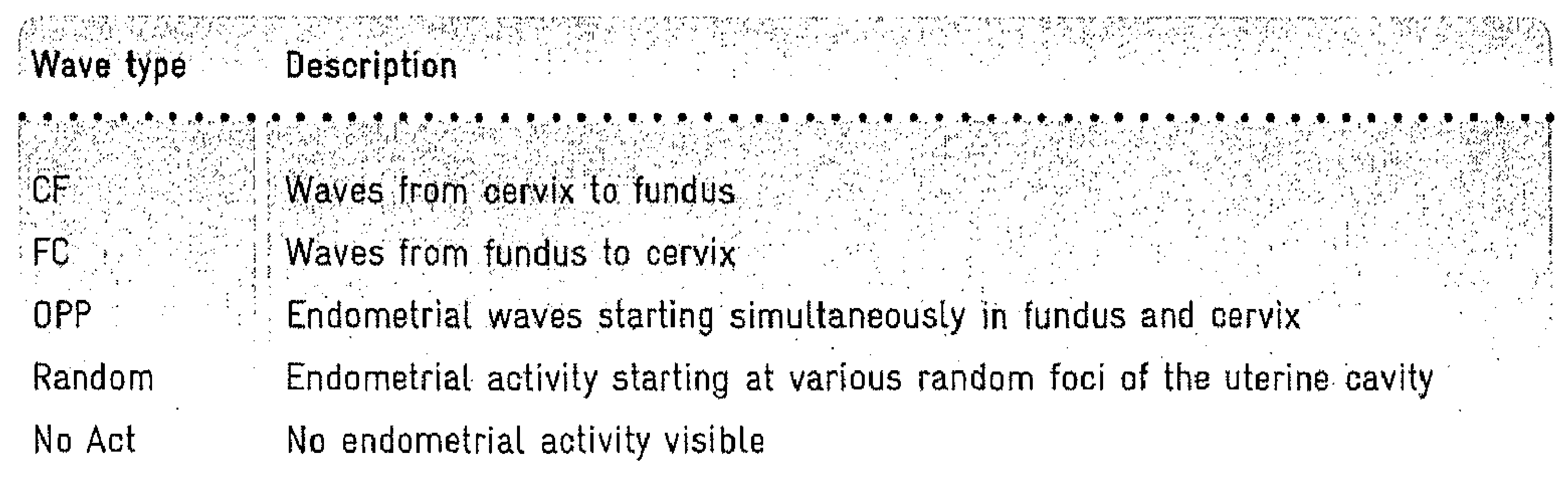

\section{Table 2.}

Revised wave classification system (present study)

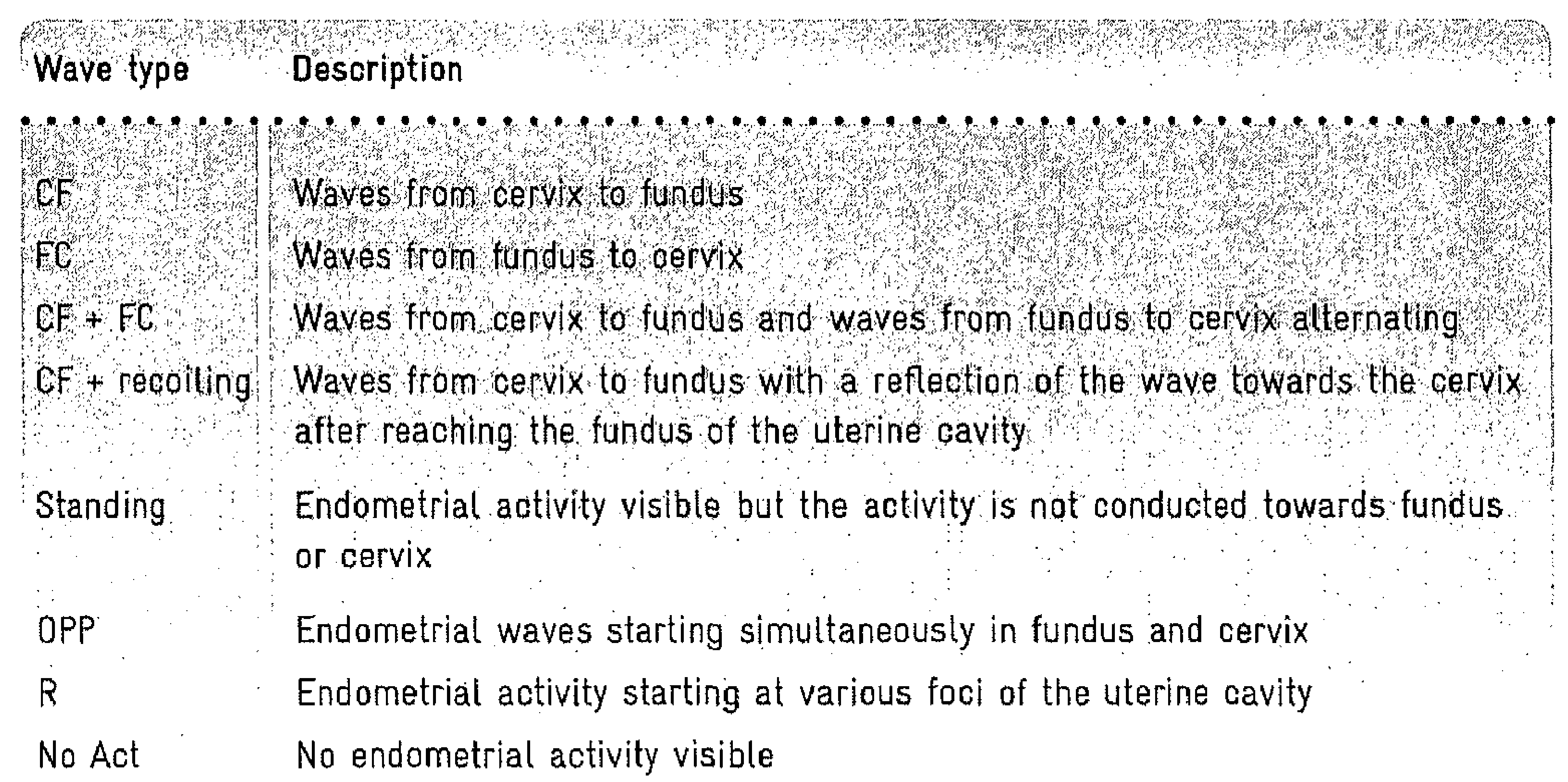




\section{Table 3.}

Wave types on the day of hCG administration, detected by three investigators, in 24 cycles (high speed). Interobserver agreement: kappa value of 0.83 .

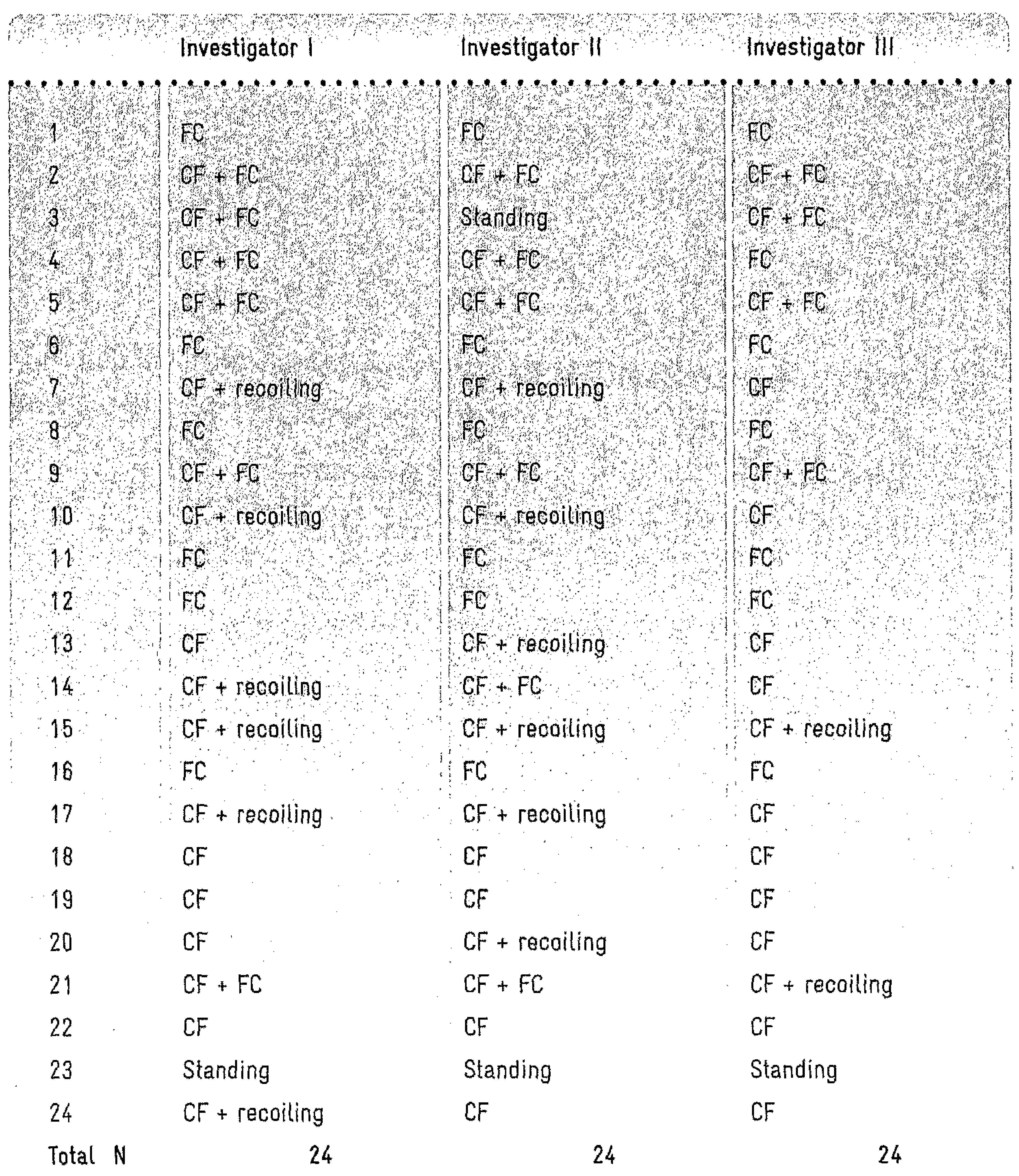




\section{Table 4.}

Real-time detection of wave types on the day of hCG administration, detected by two investigators. Interobserver agreement: kappa 0.4 . (Not classif $=$ not classifiable)

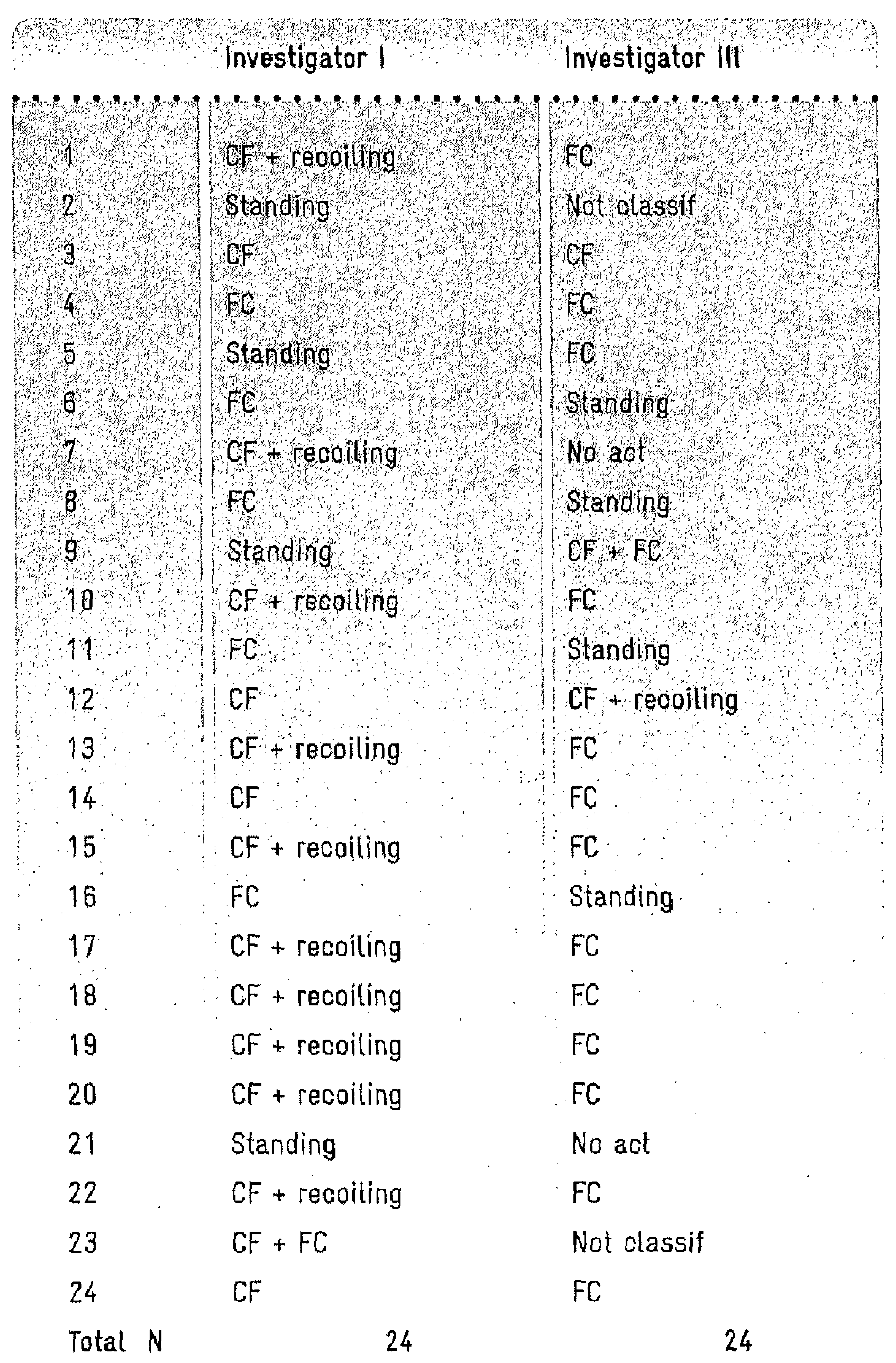




$$
\begin{array}{r}
\text { Chapter Influence } \\
\text { manipulation on } \\
\text { wave-like }
\end{array}
$$




\section{of intra-uterine endometrial activity}

van Gestel I., IJland M.M., Hoogland H.J., Evers J.L.H.

Fertility and Sterility 2007; 88: 612-615 


\section{1}

\section{Introduction}

Endometrial wave-like activity can be demonstrated by means of ultrasound, throughout the menstrual cycle. The occurrence of endometrial wave-like activity varies depending on the phase of the menstrual cycle. The overall presence of activity is most pronounced in the peri-ovulatory phase (1).

Several wave-types can be detected in different phases of the menstrual cycle as described in the endometrial wave classification system (Table 1). The predominant wave types are the unidirectional waves from fundus to cervix (FC) and the waves from cervix to fundus (CF) (2). Waves from fundus to cervix are seen in the follicular phase of spontaneous and stimulated cycles. CF waves are mainly seen in the peri-ovulatory phase. The overall activity and the direction of the endometrial wave-like activity appear to be related to fecundability in spontaneous and stimulated cycles $(1,3)$.

It has been shown that all uterine muscle cells are capable of becoming pacemaker cells to cause uterine movement. This pacemaker function can be activated by the application of oxytocin or prostaglandins, or stretching of the uterine wall $(4,5)$. For example open-tip catheters with their large volume, in intra-uterine pressure recordings, might act as a possible irritant by this mechanism (1). The activity of the muscle cells of the subendometrial myometrium seems to be coordinated by changing levels of steroid hormones throughout the cycle, like estrogens and progesterone (6).

Intra-uterine manipulation in assisted reproduction cycles, during embryo transfer and intra-uterine insemination, has been related to the initiation of uterine contractions. These contractions might lead to an immediate or delayed expulsion reaction $(7,8,9)$. Lesny and co-workers investigated the effect of a mock embryo transfer on endometrial activity in 14 volunteers. They found that easy mock transfer did not alter endometrial activity. A difficult procedure however, generated random waves in de fundal area of the uterus and waves from fundus to cervix with relocation of the transfer bolus (8). They also described an increase in overall contractility and the introduction of endometrial activity from fundus to cervix after the use of a tenaculum in mock transfer (9). 
In this chapter we describe our findings regarding the influence of intra-uterine manipulation on the direction of endometrial waves in assisted reproduction. First a pilot study was performed in IVF patients, before and after embryo transfer. Subsequently endometrial wave-like activity before and after intra-uterine insemination was investigated in stimulation cycles. 


\section{2}

\section{Embryo transfer does not influence the direction of endometrial waves}

van Gestel I., IJland M.M., Hoogland H.J., Evers J.L.H.

Human Reproduction 2001; 19: O-187 (abstract)

\section{Introduction}

In a pilot-study we compared the endometrial waves before and after embryo transfer (ET) in 15 IVF cycles, to investigate whether there is a change in the direction of endometrial wave-like activity associated with intra-uterine manipulation. 


\section{Materials and methods}

Ultrasound observations were performed in 15 women undergoing IVF. All cycles were stimulated with recombinant FSH (Puregon, Organon B.V., Oss, the Netherlands). Human Chorionic Gonadotropin (hCG 10.000 IU, Profasi, Serono, Den Haag, the Netherlands) was administered as soon as at least five follicles reached a mean diameter of $\geq 18 \mathrm{~mm}$. Embryos were transferred $40-70$ hours after insemination. Embryo transfer was done with a Frydman catheter (Laboratoire CCD, France) using a non-touch technique. If this technique failed, a more rigid and malleable TDT catheter (Laboratoire CCD, France) was used. Ultrasound examinations were performed of the uterus in the midsagittal plane, 30 minutes before and after embryo transfer, during a period of 5 to 15 minutes. The endometrial activity was recorded on video (s-VHS tapes) an analysed at highspeed replay $(4 \mathrm{x})$. The ultrasound recordings were performed by a single investigator (MIJ). The direction of the endometrial wave-like activity before and after embryo-transfer was evaluated according to the endometrial wave classification system by two investigators, independently ( $\mathrm{HH}$ and $\mathrm{IG}$ ) (2). Both investigators were blinded for pregnancy outcome.

\section{Results}

The age of the women ranged from 27 to 37 years, with a median of 32 years. There were 12 cases of primary subfertility and 3 cases of secondary subfertility. Duration of subfertility varied from 15 months to 132 months, with a median of 60 months.

Duration of stimulation with recombinant FSH ranged from 9 to 14 days (median 12). Embryo transfer of 2 or 3 embryos was performed in all 15 patients. ET was considered an easy procedure in 12 out of 15 women $(80 \%)$ and a more difficult procedure (i.e. when a TDT-catheter was needed) in 3 out of 15 women. IVF resulted in pregnancy in 8 out of 15 patients (53\%). Fourteen out of 15 patients $(93 \%$ ) showed waves from cervix to fundus before embryo transfer. After ET in 13 out of 15 women (87\%) waves from 
cervix to fundus were recorded. On the day of ET waves from fundus to cervix were never detected. One patient showed random activity before and after ET, the other patient showed CF waves before and opposing waves after ET.

In conclusion, intra-uterine manipulation by means of embryo transfer does not seem to affect the direction of endometrial wavelike activity in this study group.

\section{Discussion}

In this pilot study we investigated endometrial wave-like activity before and after embryo transfer in 15 patients undergoing IVF treatment. We observed no change in direction of endometrial wave-like activity before and after embryo transfer. Especially the introduction of waves from fundus to cervix after embryo transfer was never detected. Since FC waves might possible expel the embryo from the uterine cavity, this finding seems advantageous.

The ultrasound observations were performed a half our after the transfer, therefore it is possible that an immediate effect on the direction of wave-like activity has already disappeared. A prospective study is going to be performed in a larger study group, with ultrasound observations immediately before and after intra-uterine manipulation. 


\section{3 \\ Intra-uterine manipulation does not adversely influence the direction and frequency of endometrium waves}

Iris van Gestel, Marga M IJland, Christine Willekes, Johannes L.H. Evers, Henk J. Hoogland

Accepted for publication (2007), Fertility Sterility, Epub 2008

\section{Capsule:}

A prospective ultrasound study showed that there is no influence of intra-uterine manipulation on the direction and frequency of endometrial wave-like activity. 


\section{Abstract}

Objective: To investigate whether intra-uterine manipulation alters the direction, or affects the frequency of endometrial wave-like activity.

Design: Prospective observational study.

Setting: University hospital-based fertility clinic.

Patient(s): Thirty-six patients undergoing intra-uterine insemination (IU|).

Intervention(s): Ultrasound observation before and after IUI.

Main outcome measure(s): Endometrial wave type and endometrial wave frequency before and after IUI.

Result(s): There is no difference in the direction and frequency of endometrial waves before and after IUI in 36 patients.

Conclusion(s): Although the induction of uterine contractions by intra-uterine manipulation has been suggested in the literature, the present study shows no contractions, and neither induction of unfavorable (fundus to cervix) endometrial wave-like activity in 36 patients undergoing IUI.

Key words: Endometrial waves, endometrial wave-like activity, uterine cantractions, intra-uterine insemination, intra-uterine manipulation, endometrial wave frequency, endometrial wave classification system. 


\section{Introduction}

Throughout the menstrual cycle, endometrial wave-like activity can be demonstrated by means of ultrasound. The prevalence of endometrial wave-like activity varies depending on the phase of the menstrual cycle, with regard to their presence and wave type. The overall presence of activity is most pronounced in the periovulatory phase (1).

The predominant wave types are the unidirectional waves from fundus to cervix $(F C)$ and the waves from cervix to fundus $(C F)(2)$. Waves from fundus to cervix are seen as a rule in the follicular phase of spontaneous and stimulated cycles. They change into waves from cervix to fundus at some time during the cycle. Studying wavelike activity more in detail in the periovulatory phase revealed, next to the predominant wave types, more complex wave patterns (Table 2). $\mathrm{FC}+\mathrm{CF}$ (a combination of waves from fundus to cervix and waves from cervix to fundus), recoiling CF waves (CF waves recoiling in the direction of the cervix) and seldom random activity or a standing wave (11).

The overall activity and the direction of the endometrial wavelike activity appear to be related to fecundability in spontaneous and stimulated cycles $(1,3)$.

It has been hypothesized that intra-uterine manipulation in assisted reproduction cycles, during embryo transfer and intra-uterine insemination initiates uterine contractions, which might lead to an immediate or delayed expulsion reaction $(7,8)$. We therefore wished to investigate whether intra-uterine manipulation affects (sub)endometrial wave-like activity of the uterus. Especially the potential induction of waves from fundus to cervix after intra-uterine manipulation is of interest, since this might lead to the described expulsion reaction $(7,8)$.

In a pilot study in 15 IVF cycles we compared the endometrial waves before and after embryo transfer (ET). In this group we found no significant difference in the direction of endometrial wave-like activity before and after ET. In order to confirm the absence of an unfavourable effect of intra-uterine manipulation on the direction 
of endometrium waves (i.e. the induction of waves from fundus to cervix), we performed a prospective, observational study in a group of patients undergoing intra-uterine insemination. Sample size calculation showed that we would need at least 35 patients to reveal with $80 \%$ certainty a statistically significant change, at the $\mathrm{p}<0.05$ level in endometrial wave direction, in more than $10 \%$ of patients.

\section{Materials and methods}

Thirty-six patients undergoing intra-uterine insemination after ovulation induction or controlled ovarian hyperstimulation, participated in the study. All cycles were stimulated with human Menopausal Gonadotropin (hMG, Menogon, Ferring, Hoofddorp, the Netherlands). The patients in this study received $75-225$ Units of FSH as a single daily sc injection. Human Chorionic Gonadotropin (hCG 5000 IU, Pregnyl, Organon, Oss, the Netherlands) was administered as soon as 1 or 2 follicles in regular (monofollicular) ovulation induction and 1 to 3 follicles in controlled ovarian hyperstimulation had reached a mean diameter of $\geq 18 \mathrm{~mm}$.

Ultrasound measurement of wave direction was performed during 5-10 minutes before and 5-10 minutes immediately after intra-uterine insemination. Intra-uterine insemination with $0.3 \mathrm{ml}$ of prepared semen was performed routinely with a soft catheter (IUIcanule, Lettix b.v., Apeldoorn, the Netherlands), about 36 hours after hCG administration. If the insemination was difficult (i.e. several attempts necessary to pass the internal os or the use of a tenaculum on the cervix) this was noted.

All ultrasound examinations in stimulated cycles were performed transvaginally (7.5-MHz transducer) with the use of a real time scanner (9-HDI-ESP, Ultramark; Bothell, WA; Technos, EsaotePie Medical, Maastricht, the Netherlands). Video / DVD footage was recorded at the midsagittal plane of the uterus. The video material was digitised by means of Avid Xpress software. Analysis was performed at high-speed (4 times) replay and focused on the presence of endometrial waves and the wave type before and after intra-uterine 
manipulation. The digitised video material was analysed in arbitrary sequence and in absence of patient information.

Also the frequency of the endometrial waves before and after intra-uterine insemination was estimated. Therefore two investigators ( $\mathrm{HH}$ and IG) observed the video material from a fixed time-code-inpoint per patient. When 7-10 consecutive waves were detected the time-code-out-point was noted. The duration of the investigation period was calculated on the time-code difference (TC diff (minutes)). Based on the formula:

$(60 /$ TC diff $) *$ number of waves $=$ waves $/$ minute

the frequency of endometrial waves at that time could be calculated. Wave frequency was defined as the number of completed waves per minute.

\section{Results}

The age of the women ranged from 24 to 40 years (median 34). There were 15 patients with regular ovulation induction and 21 patients with controlled ovarian hyperstimulation. The number of follicles was 1 follicle in 15 patients, 2 follicles in 10 patients and 3 follicles in the other 11 patients. Intra-uterine insemination was considered an easy procedure in 33 out of 36 women. Treatment resulted in pregnancy in four patients $(11 \%)$ in that particular cycle. In none of the patients who became pregnant, insemination had been difficult. In the non-pregnant group, insemination was difficult in 3 patients.

\section{Wave Type}

Eleven patients showed CF waves before intra-uterine insemination, twelve patients $\mathrm{CF}$ waves with recoiling, eleven patients a combination of $\mathrm{CF}$ and $\mathrm{FC}$ waves and one patient a standing wave type. In one patient the wave type was not classifiable due to poor quality of the video material. After insemination twenty-two patients showed $\mathrm{CF}$ waves, six patients recoiling $\mathrm{CF}$ waves and six patients $\mathrm{CF}$ in combination with FC waves. In two patients a standing wave type was detected. In none of the patients a shift of CF waves (before 
IUI) to FC waves (after IUI) was detected (Table 3). The wave type before and after IUI is comparable in the pregnant and non-pregnant group. In patients in whom insemination was difficult, wave type was no different from the pattern seen in the other patients.

\section{Wave frequency}

Before intra-uterine insemination the frequency of endometrial waves ranged from $1.9 / \mathrm{min}$ to $4.3 / \mathrm{min}$ in investigator I (mean 3.2 / $\mathrm{min}$ ) and from $0.9 / \mathrm{min}$ to $5.0 / \mathrm{min}$ in investigator II (mean $3.0 / \mathrm{min}$ ) After intra-uterine insemination the frequency ranged from $1.9 / \mathrm{min}$ to $3.9 / \mathrm{min}$ in investigator $I$ (mean $3.0 / \mathrm{min}$ ) and from $1.8 / \mathrm{min}$ to $4.7 /$ $\mathrm{min}$ in investigator II (mean $3.1 / \mathrm{min}$ ) (Figure 1). There is no signifcant change in the frequency of endometrial wave-like activity due to intra-uterine manipulation. The range of frequency before and after intra-uterine manipulation, however, narrows after IUI in both investigators.

\section{Discussion}

The pattern of endometrial wave-like activity is governed by ovarian steroid hormones and FC waves are predominately seen in the first part of spontaneous and stimulated cycles. They are presumed to have a role in the elimination of menstrual debris from the uterine cavity and in constituting a barrier against the invasion of foreign pathogens $(6,12)$. The subsequent disappearance of waves from fundus to cervix is supposed to be mandatory in order to prevent the embryo or semen from being expelled out of the uterine cavity.

In the present study we have prospectively investigated a group of 36 patients undergoing intra-uterine insemination. In ultrasound observation of endometrial wave-like activity before and after IUI, a switch from $\mathrm{CF}$ waves to $\mathrm{FC}$ waves was never detected $(0 / 36=0 \%$, $95 \%$ Cl $0-10 \%)$. 
Waves from cervix to fundus appear to play a role in sperm transport $(13,14)$. In the present study group the more complex wave types ( $\mathrm{CF}+$ recoiling, $\mathrm{CF}+\mathrm{FC}$ waves and standing wave type) often disappear in favour of the unidirectional CF wave. Pure CF waves can be demonstrated twice as frequent after IUI ( $31 \%$ before IUI, $62 \%$ after IUI). This supports the contention of unidirectional CF waves playing a pivotal role in sperm transport towards the Fallopian tubes and may explain the early entry of spermatozoa into the peritoneal cavity, only minutes after insemination.

Also the frequency of endometrial wave-like activity is governed by ovarian steroid hormones and is highest in the periovulatory phase. In the second half of the cycle the uterus becomes more quiescent $(2,13)$. Wave frequency is higher in stimulated than in spontaneous cycles $(12,15)$. Although it has been hypothesized that the frequency of endometrium waves is influenced by intra-uterine manipulation, we found no difference in the mean frequency of endometrial wavelike activity on a per-patient basis in 36 patients before and after intra-uterine insemination. The range of frequencies detected after IUI however narrows in comparison to the range before IUI. This change might constitute an artefact since it might be due to the fact that the presence of $0.3 \mathrm{ml}$ fluid in the uterine cavity facilitates visualisation of endometrial activity.

Previous literature suggests that intra-uterine manipulation may initiate uterine contractions, with a possible negative effect on pregnancy results in assisted reproduction $(7,8)$. Therefore it seems logical to presume a relation between direction of endometrial wavelike activity and embryo transfer or intra-uterine insemination. The appearance of waves from fundus to cervix after intra-uterine manipulation might lead to the described expulsion reaction. In the present study we found no switch from $\mathrm{CF}$-waves to $\mathrm{FC}$-waves in 36 IUI patients. This means that we can exclude with $80 \%$ certainty a significant change $(\mathrm{p}<0.05)$ of wave direction towards FC waves occurring in more than $10 \%$ of patients. 


\section{References}

1. van Gestel, IJland MM, Hoogland HJ, Evers JLH. Endometrial wavelike activity in the non-pregnant uterus. Hum Reprod Update 2003; 9: 131-8.

2. IJland MM, Evers JLH, Dunselman GAJ, Katwijk C, Lo CR, Hoogland HJ, Endometrial movements during the menstrual cycle. Fertil Steril 1996; 65:746-9.

3. IJland MM, Evers JLH, Dunselman GAJ, Volovics L, Hoogland HJ. Relation between endometrial wavelike activity and fecundability in spontaneous cycles. Fertil Steril 1997; 67; 492-96.

4. Garfield RR and Yallampalli C. (1994) Structure and function of uterine muscle. In Chard T, Grudzinskas JG (eds) The Uterus, Press Syndicate of the University of Cambridge, Cambridge, United Kingdom.

5. Richter ON, Bartz C, Dowaij J, Kupka M, Reinsberg J. Utrich U, Rath W. Contractile reactivity of human myometrium in isolated non-pregnant uteri. Hum. Reprod 2006; 21: 36-45.

6. IJland MM, Willekes C, Hoogland HJ, Dunselman GAJ, Evers JLH (2000). Modelling endometrial wavelike activity in hypoestrogenic women. Thesis, Maastricht.

7. Lesny P, Killick SR, Telow RL, Robinson J, Maguiness SD. Embryo transfer- can we learn anything new from the observation of junctional zone contractions? Hum Reprod 1998; 13: 1540-46.

8. Mansour RT, Aboulgar MA. Optimizing the embryo transfer technique. Hum Reprod 2002; 17: 1149-1153.

9. Woolcott R, Stanger J. Ultrasound tracking of the movement of embryoassociated air bubbles on standing after transfer. Hum Reprod 1998; 13 2107-2109.

10. Lesny P, Killick SR, Robinson J, Raven G, Maquines SD. Junctional zone contractions and embryo transfer: is it safe to use a tenaculum? Human Reprod 1999; 14: 2367-2370.

11. van Gestel I, IJland MM, Evers JLH, Hoogland HJ. Complex endometrial wave-patterns in IVF. Fertil Steril 2007; 88: 612-615.

12. IJland MM, Hoogland HJ, Dunselman GAJ, Lo C, Evers JLH. Endometrial wave direction switch and the outcome of in vitro fertilization. Fertil Steril 1999; 71: 476-81.

13. Lyons EA, Taylor PJ, Zheng XH, Ballard G, Levi CS, Kredenstser JV. Characterization of subendometrial myometrial contraction throughout the menstrual cycle in normal fertile women. Fertil Steril 1991; 55; 771-774. 
14. Kunz $G$, Beil $D$, Deininger $H$, Wildt $L$, Leyendecker $G$. The dynamics of rapid sperm transport through the female genital tract: evidence from vaginal sonography of uterine peristalsis and hysterosalpingography. Hum Reprod 1996; 11: 627-632.

15. Ayoubi JM, Epiney M, Brioschi PA, Fanchin R, Chardonnens D, de Ziegler D. Comparison of changes in uterine contractions frequency after ovulation in the menstrual cycle and in in vitro fertilization cycles. Fertil Steril 2003; 79 : $1101-1105$ 


\section{Table 1.}

The wave classification system (2)

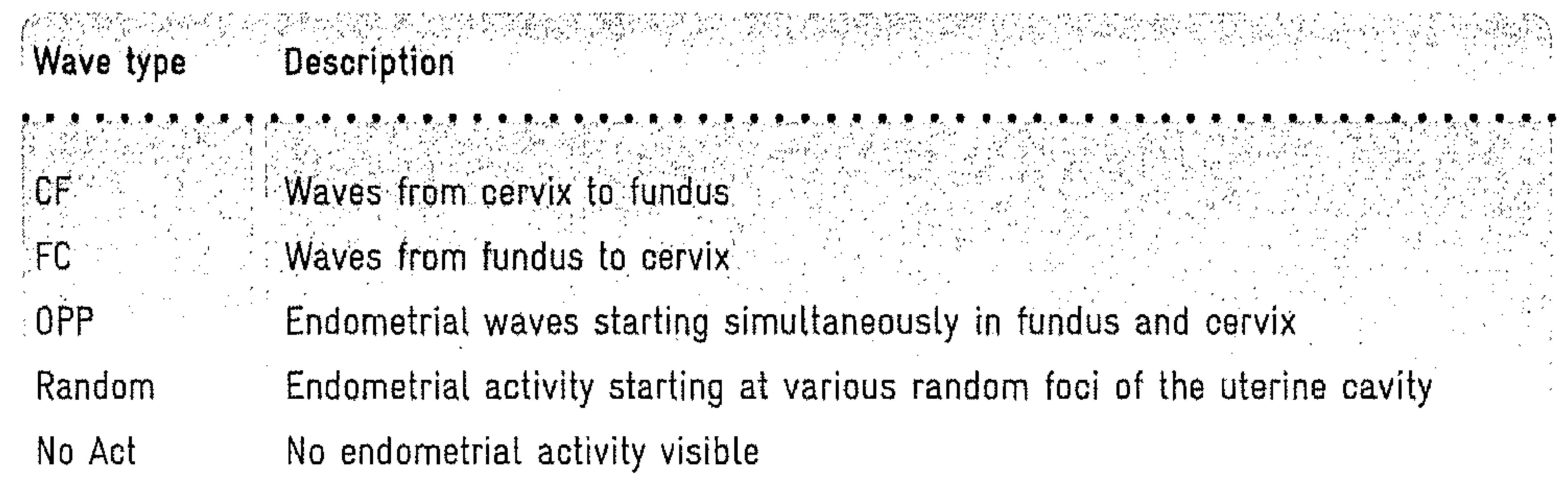

\section{Table 2.}

Revised wave classification system (11)

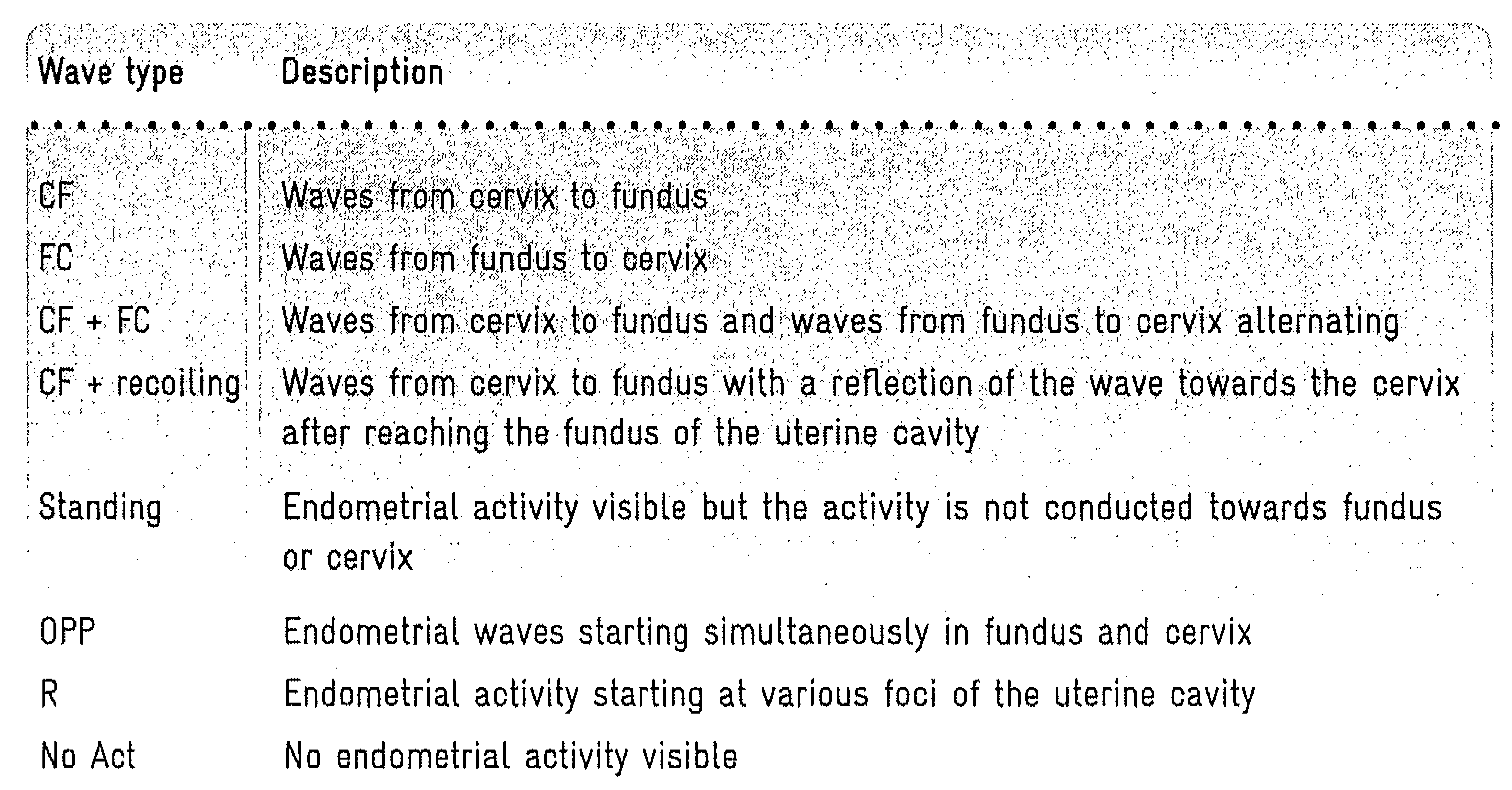




\section{Table 3.}

Wave type before and after intra-uterine insemination

(CF = waves from cervix to fundus, $F C=$ waves from fundus to cervix $)$
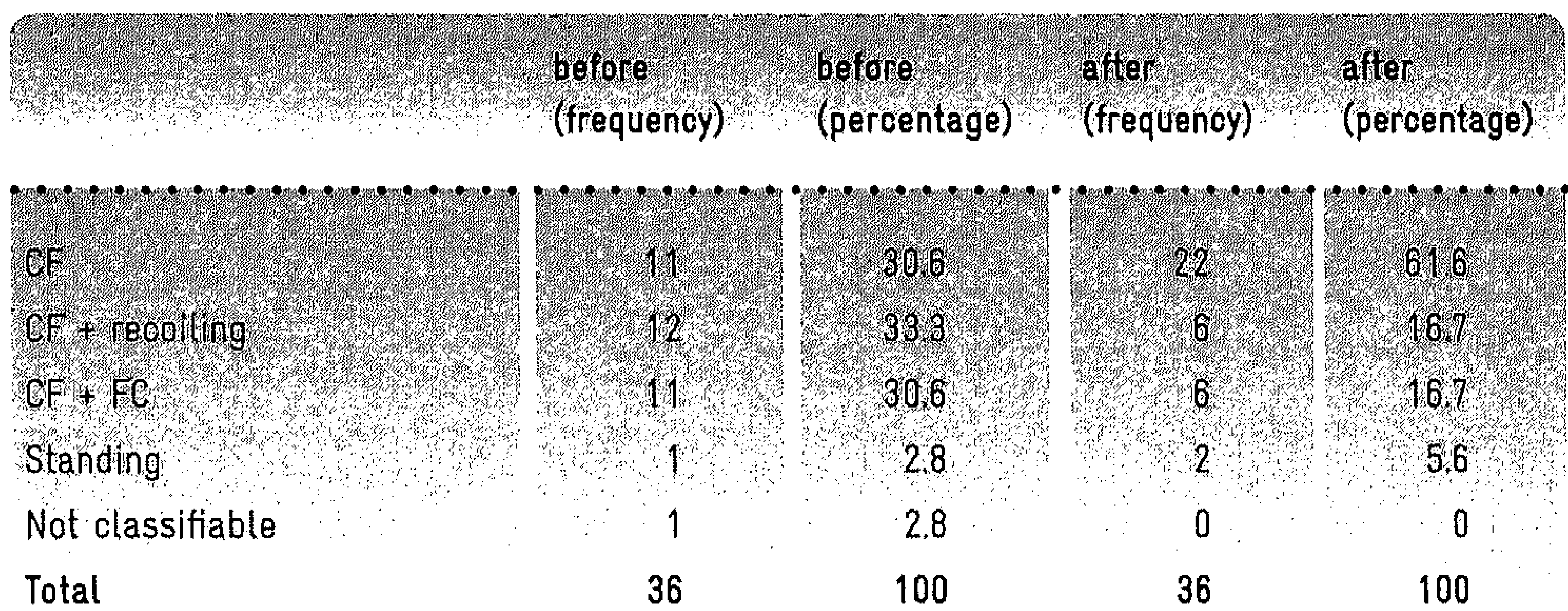

\section{Figure 1.}

Wave frequency (i.e. number of waves per minute) before and after intra-uterine insemination by investigator $\mathrm{I}(\mathrm{HH})$ and investigator $I I(I G)(60 /$ Time-code difference $) *$ number of waves = wave frequency

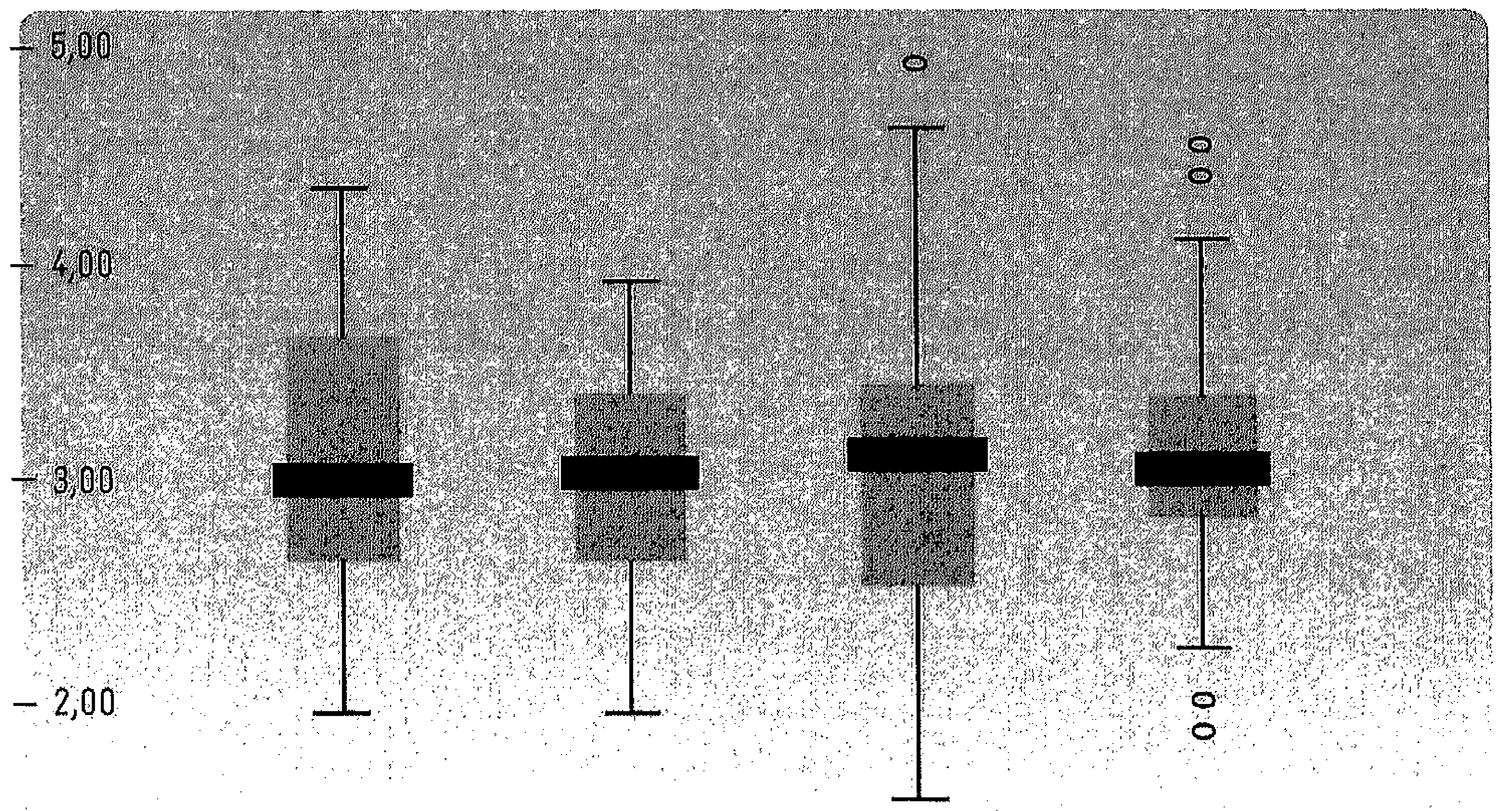

$-1,00$
Investigator I
Investigator 1
$\stackrel{i}{i}$ Investigator II
Investigator 11
Before $|U|$
After IUI
Before IUI
After IUI 
Chapter 6

\section{waves fail to predict in a prospective}




\section{Endometrial}

\section{IVF outcome study}

Iris van Gestel, Marga M. IJland, Johannes L.H. Evers, Henk J. Hoogland Submitted for publication 


\begin{abstract}
Background:

The aim of the present study was to closely study wave-like activity throughout IVF cycles and describe this activity according to a revised classification system. The hypothesis was tested that coordinated activity, being waves from fundus to cervix or waves from cervix to fundus and no combinations of wave types, was associated with favourable IVF outcome.
\end{abstract}

\title{
Methods:
}

In a prospective observational study ultrasound observations were performed in 132 IVF cycles to detect endometrial wave type and frequency, as well as ultrasound parameters like texture and thickness of the endometrium. These parameters were related to IVF outcome.

Results:

94 IVF cycles resulted in embryo transfer. Forty-two of these cycles resulted in pregnancy. More complex wave patterns according to the revised classification system could be confirmed in these IVF cycles. Coordinated endometrial activity was not significantly related with higher pregnancy chance $(52.6 \%$ pregnant versus $47.4 \%$ non-pregnant in the group with coordinated activity; $30 \%$ pregnant versus $70 \%$ non-pregnant in the group with uncoordinated activity, $P=0.13$ ). Also the results of other ultrasound parameters like endometrial wave type, wave frequency, endometrial texture and thickness on different moments in the cycle were not related to IVF outcome.

\section{Conclusions:}

Coordinated activity of the endometrium is not associated with favourable IVF outcome. The various characteristics of endometrial wave-like activity, as detected by ultrasound in this study group, can not be used as a predictor of IVF outcome.

Key words: endometrial waves, endometrial wave-like activity, endometrial wave frequency, endometrial wave classification system, IVF. 


\section{Introduction}

In 1984 Birnholz first used ultrasound technique to study movements of the non-pregnant uterus in a non-invasive way (Birnholz, 1984). The subsequent recording of endometrial activity by several authors with diverse techniques resulted in a description of different patient groups, with variable recording methods and the ensuing variation in classification of the activity patterns (for review: van Gestel et al., 2003). Most studies showed movements from fundus to cervix during the early follicular phase. Movements from cervix to fundus were described in the late follicular and peri-ovulatory phase. An increased intensity of movements was detected towards ovulation by most authors (for review: van Gestel et al., 2003).

The endometrial wavelike activity appears to play a role in the reproductive process (Bulletti et al., 2006). In spontaneous cycles a relation was found between the endometrial waves and fecundity. An overall dampening of endometrial activity in the late follicular phase and a predominance of CF waves were described in conception cycles compared to non-conception cycles (IJland et al., 1997).

A study of 22 IVF cycles showed a relation between the direction of endometrial activity on the day of hCG administration and eventual pregnancy outcome. The persistence of waves from fundus to cervix until the moment of hCG administration was associated with a favourable pregnancy outcome (IJland et al., 1999). A validation study in 90 IVF patients on the day of hCG administration however, could not confirm the relation between the endometrial wave type and pregnancy outcome on this particular day of the cycle (van Gestel et al., 2005).

In IVF cycles Fanchin and co-workers found a relation between a dampening of uterine activity and improved pregnancy outcome (Fanchin et al., 1998a, b). They described that a higher frequency of endometrial contractions on the day of embryo transfer resulted in a lower IVF-embryo transfer outcome. IJland and co-workers found no relation between wave frequency in IVF-cycles and outcome, in the previously described 22 IVF cycles (IJland et al., 1999). Furthermore no relation was found between IVF outcome and the endometrial thickness and texture in this group (IJland et al., 1999). 
After studying spontaneous cycles, an endometrial wave classification system was developed by our study group to describe the different activity types of the endometrium (IJland et al., 1996). While using this classification system in subsequent investigations in stimulation cycles, it became increasingly clear that not all movements could be classified according to the original criteria. To be able to describe endometrial activity in more detail, the existing endometrial wave classification system was expanded, resulting in a refined wave classification system (Table 1) (van Gestel et al., 2007).

In order to investigate endometrial wave-like activity in a larger study group, we performed a prospective observational study. The aim of the study was to describe the endometrial activity more in detail according to the refined endometrial classification system on different moments in the IVF cycle (van Gestel et al., 2007) and relate the endometrial activity to IVF outcome.

We hypothesized coordinated endometrial activity to be a prerequisite for favourable implantation conditions, based on previous results showing a higher pregnancy rate in a quieter uterus (IJland $e t$ al., 1997). In the refined classification system we described CF waves or FC waves (coordinated waves) and combinations of wave types (uncoordinated waves). We therefore decided to measure coordinated and uncoordinated endometrial activity in different phases of the cycle and relate it to the occurrence of pregnancy.

We have also investigated whether or not we could corroborate the results of former studies with regard to the frequency of endometrial waves in IVF treatment (Fanchin et al., 1998 a,b).

In previous IVF studies we focused on the day of hCG administration (IJland et al., 1999, van Gestel et al., 2005), because it is the time that in the IVF clinic important decisions have to be made (van Gestel et al., 2003). Furthermore endometrial activity is most pronounced in this period. In this study we increased the amount of measurements throughout the IVF cycle. We have still considered the period close before hCG administration to be an important period in the analysis of endometrial activity however. 
In summary, a number of ultrasound parameters have been suggested to play a role in the endometrial receptivity. Next to endometrial thickness and texture, the activity of the uterus as classified by means of the endometrial wave type and frequency can be described. In this observational study we intend to investigate the role of these various ultrasonographic endometrial parameters in relation to fecundity.

\section{Materials and methods}

Ultrasound observations were performed in 132 subsequent IVF cycles. There were no exclusion criteria to participate in the study. This study was approved by our hospital's ethics committee, and all participants gave informed consent.

All cycles were stimulated using recombinant FSH (r-FSH, Puregon, Organon, Oss, the Netherlands) in combination with intranasal administration of a $\mathrm{GnRH}$-analogue ( $\mathrm{GnRH}-\mathrm{a})$ triptoreline (Decapeptyl $0.5 \mathrm{mg} / \mathrm{ml}$ s.c., 1 d.d.; Ferring BV, Hoofddorp, The Netherlands). Recombinant FSH was started after suppression of ovarian function with the GnRH-a. The patients in this study received $100 \mathrm{E}-250 \mathrm{E}$ of $\mathrm{rFSH}$ as a single daily sc injection. Follicular growth was assessed by ultrasound. Human Chorionic Gonadotropin (hCG 5000 IU, Pregnyl, Organon, Oss, the Netherlands) was administered as soon as at least three follicles reached a mean diameter of $\geq 18 \mathrm{~mm}$. E 2 determinations are not routinely performed in our clinic. On the day of hCG administration, recombinant FSH and $\mathrm{GnRH}-\mathrm{a}$ were discontinued.

Oocyte retrieval was performed under vaginal ultrasound guidance 34 hours after hCG administration. Embryos were transferred 2-4 days after insemination. Patients received vaginal progesterone tablets for luteal support (Progestan 3 doses of $200 \mathrm{mg}$, Organon, Oss, the Netherlands).

Ultrasound measurements of wave direction were performed on the days of routine OPD visits for IVF treatment. A subgroup of patients had one extra ultrasound recording in the luteal phase. The examination was performed transvaginally (7.5- $\mathrm{MHz}$ transducer) 
with the use of a real-time scanner (Technos, Esaote-Pie medical, Maastricht, the Netherlands). All ultrasound measurements were performed by a single observer (IG).

Three minutes of endometrial activity was recorded and digitally stored on DVD. The recorded material was digitized by means of Avid Xpress software (Avid Technology, Tewksbury, USA). Analysis of the digitized material was performed at high-speed replay (4 times).

\section{Wave type}

The endometrial activity was described by means of the refined wave classification system, which distinguishes eight types of endometrial movements, namely: waves from fundus to cervix (FC); waves from cervix to fundus $(\mathrm{CF})$; the combination of $\mathrm{CF}$ and $\mathrm{FC}$ waves $(\mathrm{CF}+\mathrm{FC})$; the recoiling $\mathrm{CF}$ wave $(\mathrm{CF}+$ recoiling); the standing wave (standing); opposing waves (OPP); Random waves $(\mathrm{R})$ and No activity (No Act) (Table 1). We considered the day of hCG administration as day 0 . The different measurement moments were related to the day of hCG administration. Because ultrasound recordings were performed on the days of routine OPD visits, not all patients were seen on the day of hCG administration. Therefore the reference day of a patient was the day of hCG administration, or the moment of ultrasound recording closest before hCG administration.

Pure CF or FC waves during one investigation period are considered the coordinated wave types. Uncoordinated waves are all other wave types, with the exception of no activity and non-classifiable endometrial activity. The occurrence of these subgroups of wave-types was encountered throughout the IVF cycle.

The detected endometrial wave types throughout the cycle were related to IVF outcome.

\section{Wave frequency}

Wave frequency was defined as the number of waves completed per minute. The frequency was calculated for every ultrasound observation in which endometrial activity could be properly detected. One investigator $(\mathrm{HH})$ observed the video material throughout 
7-10 consecutive, complete waves (nr of waves). At the start of the observation the time-code-in-point was noted. When 7-10 waves were detected the time-code-out-point was noted. The duration of the investigation period was calculated on the time-code difference (TC diff (minutes)). Based on the formula: (nr of waves / TC diff) * $60=$ waves per minute, the frequency of endometrial waves at that time could be calculated.

Wave frequency per patient during that particular IVF cycle was related to IVF outcome in that same cycle.

\section{Endometrial thickness and texture}

Endometrial thickness was measured as the maximum distance between the two myometrial interfaces in the midsagittal plane of the uterus. The endometrial texture was classified into three types, i.e. type I, multilayered, triple-line endometrium, consisting of a prominent hyperechogenic outer and central layer and hypoechogenic inner layers; type II, intermediate isoechogenic pattern, with the same reflectivity as the surrounding myometrium and a poorly defined central echogenic line; type III, entirely homogeneous, hyperechogenic pattern (Goonen, 1990).

The endometrial aspects like thickness and texture were related to IVF outcome.

\section{Statistical methods}

For the sample size calculation we have taking into account an expected drop-out of about $30 \%$. We therefore needed to include at least 130 patients to reveal with $80 \%$ certainty a statistically significant difference $(\mathrm{p}<0.05)$ between coordinated en uncoordinated endometrial activity.

Statistical analysis was performed by the SPSS software program (12.0). Chi-square tests were used to calculate statistical differences. A p-value of 0.05 was considered significant. Considering the complexity of the fertilization process, other factors like patients age, duration of subfertility, embryo quality were taken into account in a multivariate analysis. 


\section{Results}

One hundred and thirty-two IVF cycles were monitored in 132 different patients. In 27 cycles treatment was discontinued because of poor response or threatening ovarian hyperstimulation syndrome. There was one drop-out because the patient no longer wanted to participate in the study. In one cycle there was no ovum pick-up and in 9 cycles no embryo transfer could be performed. Ninety-four cycles could be used for further analysis.

The age of the women ranged from 21 to 41 years, with a median of 34 years. There were $58(62 \%)$ cases of primary subfertility and $36(38 \%)$ cases of secondary subfertility. Duration of subfertility varied from 1 to 9 years, with a median of 3.5 years. Causes of subfertility were tubal pathology ( $N=12$ ), endometriosis ( $N=2)$, unexplained subfertility ( $N=23$ ), male subfertility ( $N=48$ ) and preimplantation genetic diagnosis (PGD) ( $N=9$ ).

Duration of stimulation with recombinant FSH ranged from 7 to 21 days, with a median of 12 days. Patients were stimulated with 100 to $250 \mathrm{E}$ of FSH. The total number of oocytes retrieved ranged from 3 to 20 , with a median of 8 . One embryo was transferred in 41 patients; in 53 patients 2 embryos were transferred. The number of embryos was based on the quality of the embryos available for transfer.

Forty-two of the 94 women conceived $(45 \%)$ and in $33(35 \%)$ patients there was an ongoing pregnancy.

\section{Wave type}

In the first days of the stimulation period (day hCG-20 to hCG-7) there was usually no activity of the endometrium detectable (71 out of 100 measurements). Towards the day of hCG administration waves from fundus to cervix (FC waves) were most frequently detected with a gradual switch to waves from cervix to fundus (CF waves). After ovum pick-up FC waves were no longer detected. (Figure 1) The combination of CF-waves and FC-waves and the standing wave type were seen from day hCG-10 of the stimulation period until the day of ovum pick-up ( 60 versus 44 out of 348 measurements) and less frequent in the following period ( 8 versus 6 out 
of 96 measurements). Recoiling CF-waves were rarely detected in the phase preceding ovum pick-up (5 out of 348 measurements). In the small group that was examined in the midluteal phase $(\mathrm{N}=17)$ we most often found CF waves or no activity (Figure 1).

In 92 out of 517 recordings throughout the whole IVF-cycle the endometrial wave type could not be established $(17.8 \%)$. In these recordings endometrial wave activity could not be classified, due to the position of the uterus or suboptimal image quality. On the day of embryo transfer (day hCG +4 to $h C G+6$ ) in 51 out of 79 patients $(65 \%)$ the direction of endometrial waves could not be classified due to artifacts, introduced by the full urinary bladder and the fluid surrounding the uterus following the ovum pick-up (Figure 1).

There was no significant relation between the individual endometrial wave-types throughout the IVF cycle and the outcome (Figure 2).

In order to compare endometrial wave-like activity for the study population as a whole, we defined an individual "reference day"; preferably being the day of hCG administration otherwise the day closest before the day of hCG administration. The reference day was hCG -3 for $2.2 \%$, hCG -2 for $7.7 \%$, hCG -1 for $44 \%$ and the day of hCG administration for $46.2 \%$ of patients. The reference day was comparable in the pregnant and in the non-pregnant group (mean day -0.74 versus -0.65 ). Also when focusing on this reference day, there was no significant relation between the wave type and IVF outcome.

Throughout the IVF cycle coordinated wave types (FC- or CFwaves) are detected in 206 out of 517 measurements compared to uncoordinated wave types in 131 out of 517 (39.8\% versus $25.3 \%$ ). On the reference day, coordinated wave types are associated with pregnancy in 30 out of 57 cycles (27 out of 47 non-pregnant). In patients with uncoordinated wave types on that particular day, 9 out of 30 conceived (versus 21 out of 30 non-pregnant). This difference in the occurrence of coordinated wave types in conception cycles compared to non-conception cycles is not statistically significant $(\mathrm{P}=0.13)$ (Figure 3 ). 


\section{Wave frequency}

The wave frequency increases towards midcycle, to decrease again after ovum pick-up (Table 2). The mean wave frequency before the day of hCG administration is 3.32 waves / min (minimum 1.66 waves / minute, maximum 5.00 waves / minute). After hCG administration the median wave frequency is 2.99 waves / min (minimum 1.33 waves / $\mathrm{min}$, maximum 5.02 waves / $\mathrm{min}$ ). There is no statistically significant difference in wave frequency before and after hCG administration and overall wave frequency, in pregnant and nonpregnant cycles (Table 2).

\section{Endometrial thickness and texture}

The endometrial thickness increases to $10.5+/-2.2 \mathrm{~mm}$ on the day of embryo transfer (ET) (minimum $6 \mathrm{~mm}$, maximum $16 \mathrm{~mm}$ ). The endometrial thickness and the endometrial growth towards the day of embryo transfer, is not related to pregnancy outcome.

Endometrial texture changed from homogeneous at the beginning of the stimulation cycle to triple-line $(78 \%)$ or intermediate $(18 \%)$ endometrium on the reference day. On the day of embryo transfer the texture was homogeneous in the majority of cases (68\%). No relation was found between conception cycles and endometrial texture, in these patients undergoing IVF treatment.

In the group of IVF patients in whom embryo transfer could be performed, pregnant cycles were comparable to non-pregnant cycles regarding age, duration of subfertilty, parity, number of oocytes and embryo quality. A multivariate analysis of all ultrasound parameters and other parameters of this population on the reference day showed no independent factor influencing IVF outcome. 


\section{Discussion}

The non-pregnant uterus shows wave-like activity in the endometrial layer. These endometrial movements originate in the subendometrial myometrium (Kunz et al., 2000) and are presumed to be governed by steroid hormones (Noe et al., 1999, IJland et al., 2000). Endometrial development and activity are likely to play an important role in the receptivity of the uterus. Therefore many studies have been performed to describe the endometrial activity and relate it to pregnancy outcome in spontaneous and stimulated cycles (for review: van Gestel et al., 2003).

In the present study we have prospectively investigated a group of 132 IVF patients during their routine visits at our IVF clinic. Ultrasound examinations were performed during 3 minutes to describe the various endometrial wave-types, the wave pattern throughout the cycle and aspects of the endometrium such as thickness and texture.

In the 94 patients in whom ET could be performed, little endometrial activity was seen in the beginning and at the end of the IVF cycle. During the stimulation period waves from fundus to cervix were predominantly seen, with a gradual switch towards waves from cervix to fundus towards the end op the stimulation period. Combinations of wave-types were most frequently seen in the period prior to ovum pick-up.

The pattern of endometrial activity as described is in concordance with previous findings (for review: van Gestel et al., 2003). Also the phenomenon of the endometrial wave direction switch, being the switch of waves from fundus to cervix into cervix-fundus waves, can still be confirmed (IJland et al., 1999).

In our previous study we could not validate the presumed positive effect of a late wave direction switch on pregnancy chances (van Gestel et al., 2005). The present study shows no relation between the endometrial wave type on different moments of the IVF cycle and IVF outcome either.

We previously described that coordinated endometrial activity, i.e. a relatively quiet uterus, seems to benefit the receptivity of the uterus (IJland et al., 1997). To investigate that, we divided endometrial wave-like activity into coordinated and uncoordinated activity. 
In the present study group we have not found a statistically significant difference in pregnancy rate between coordinated and uncoordinated wave-like activity. Therefore we have to reject our primary hypothesis that the occurrence of coordinated wave-like activity is beneficial for IVF outcome in this study group.

Wave frequency was determined on different moments in the IVF cycle. The decrease in wave frequency we described towards the luteal phase is in accordance with the findings of Fanchin and co-workers (Fanchin et al., 2001). We found no relation between wave frequency and IVF outcome. Fanchin and co-workers however, found a relation between lower wave frequency on the day of embryo transfer and pregnancy rate (Fanchin et al., 1998 a, b). In our study we have been able to calculate the frequency of endometrial waves only in 16 out of 94 patients on the day of ET, due to the previously mentioned artifacts. Therefore we can not reliably compare the results on that particular day.

In this study group we can confirm that the endometrium becomes thicker throughout the stimulation period and that the texture changes from a triple-line at midcycle back to homogeneous in the luteal phase. As in our previous small study group we found no relation between endometrial thickness and texture, and pregnancy rates (IJland et al., 2000).

In conclusion, our present prospective study in IVF cycles has confirmed previously described patterns of endometrial activity throughout the stimulation cycle. By using the refined endometrial wave classification system, the unidirectional wave-types (CF waves or FC waves) are still predominantly detected. The suggested function of these unidirectional wave-types, being a cleansing role of the uterus for FC-waves and a promoting effect on sperm transport for $\mathrm{CF}$-waves, is still plausible.

After the former investigation, endometrial wave-like activity was presumed a promising factor in determining the receptivity of the uterus. In the present study a relationship between endometrial activity throughout the IVF cycle and IVF outcome could not be 
confirmed. Multivariate analysis did not show any other independent factor predicting IVF outcome in this study.

The phenomenon of endometrial wave-like activity is an interesting subject of investigation and an important role for this activity in the reproductive process seems very likely. To reveal a possible significant relation between endometrial waves and fecundity we need such a large study group that the merit for the clinical situation is questionable. Therefore we conclude after this prospective study that the actual ultrasound imaging techniques to study endometrial wavelike activity are not able to prove any clinical value of this interesting physiologic phenomenon. 


\section{References}

1. Birnholz JC (1984) Ultrasonic visualization of endometrial movements. Fertil Steril 41, 157-8

2. Bulletti $C$, de Ziegler $D$ (2006) Uterine contractility and embryo implantation. Curr Opin Obstet Gynacol 18, 473-484.

3. Fanchin R, Righini C, Ayoubi JM (1998) Uterine contractions at the time of embryo transfer: a hind implantation? Contracept Fertil Sex 26, 498-505.

4. Fanchin R, Rhigini C, Olivennes F, Taylor S, de Ziegler D, Frydman R (1998) Uterine contractions at the time of embryo transfer alter pregnancy rates after in-vitro fertilization. Hum Reprod 13, 1968-74.

5. Fanchin R, Ayoubi JM, Righini $C$, Olivennes $F$, Schonauer LM, Frydman $R$ (2001) Uterine contractility decreases at the time of blastocyst transfers. Hum Reprod 16, 1115-1119.

6. Goonen $Y$ and Asper RF (1990) Prediction of implantation by the sonographic appearance of the endometrium during controlled ovarian stimulation for in vitro fertilization (IVF). J In Vitro Fertil And Embryo Transf 7, 146-152.

7. IJland MM, Evers JLH, Dunselman GAJ, van Katwijk C, Lo CR, Hoogland HJ (1996) Endometrial wavelike movements during the menstrual cycle. Fertil Steril 65, 746-749.

8. IJland MM, Evers JLH, Dunselman GAJ, Volovics L, Hoogland HJ (1997) Relation between endometrial wavelike activity and fecundability in spontaneous cycles. Fertil Steril 67, 492-96.

9. IJland MM, Hoogland HJ, Dunselman GAJ, Lo CR, Evers JHL (1999) Endometrial wave direction switch and the outcome of in vitro fertilization. Fertil Steril 71, 476-81.

10. Kunz G, Kissler S, Wildt L, Leyendecker G (2000) In Filicori M (eds) Endocrine Basis of Reproductive Function. Monduzzi Editore, Bologna, Italty.

11. Noe M, Kunz G, Herbertz M, Mall G, Leyendecker G (1999) The cyclic pattern of the immunocytochemical expression of oestrogene and progesterone receptors in human myometrial and endometrial layers: the characterization of the endometrial-myometrial unit. Hum Reprod 14, 190-197.

12. van Gestel I, IJland MM, Hoogland HJ and Evers JLH (2003) Endometrial wave-like activity in the non-pregnant uterus. Hum Reprod Update 9, 131-8.

13. van Gestel I, IJland MM, Hoogland HH and Evers JLH (2005) Endometrial waves in in vitro fertilization cycles: a validation study. Fertil Steril 83, 491-3.

14. van Gestel I, IJland MM, Evers JLH, Hoogland HJ (2007) Complex endometrial wave-patterns in IVF-cycles. Fertil Steril, 88, 612-615. 


\section{Table 1.}

Refined wave classification system (van Gestel, 2007)

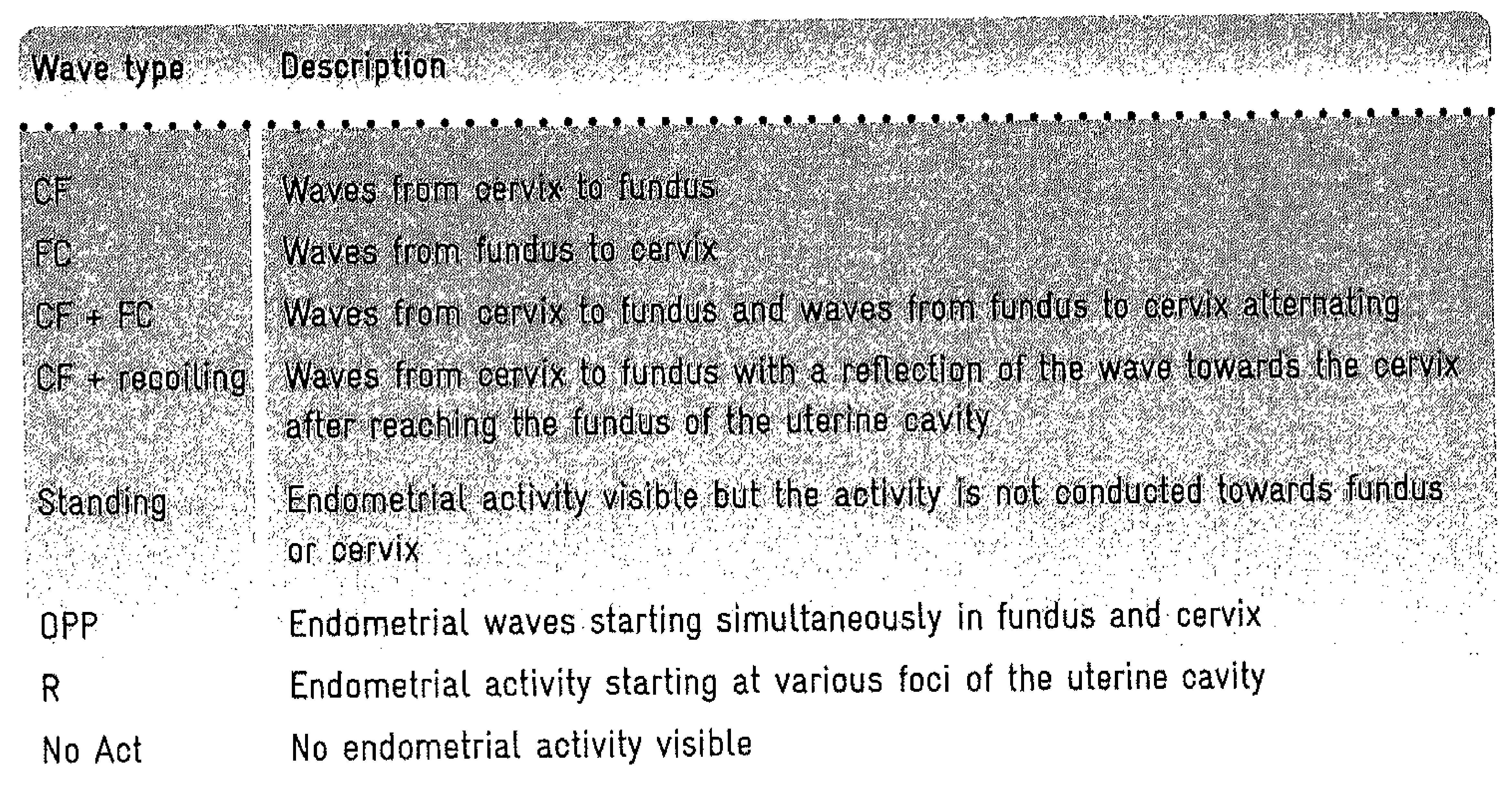

\section{Table 2.}

Frequency of endometrial waves throughout the IVF cycle (waves per minute).

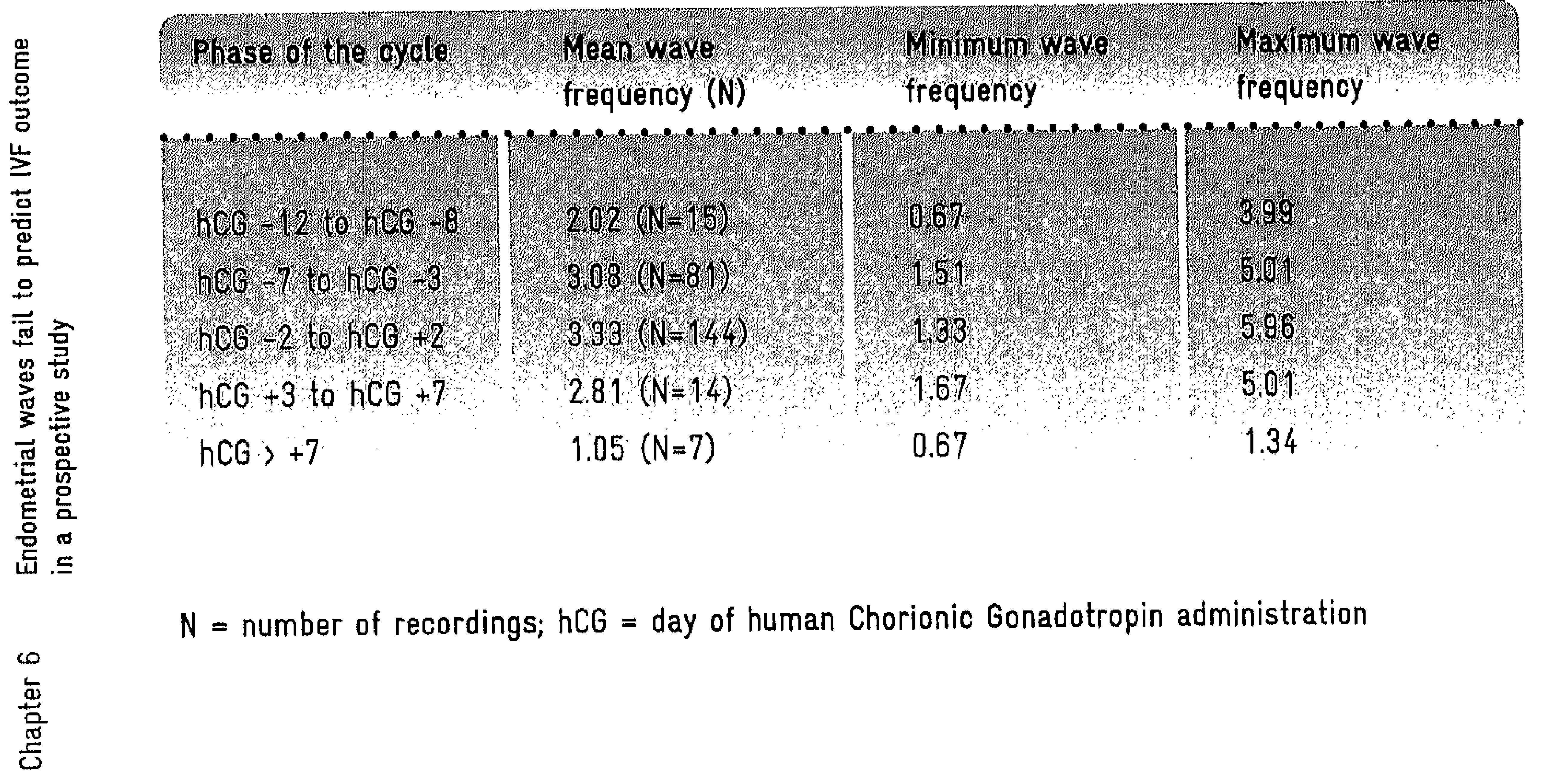


Figure 1.

Overall distribution of various wave types throughout the IVF cycles,

related to the day of hCG administration

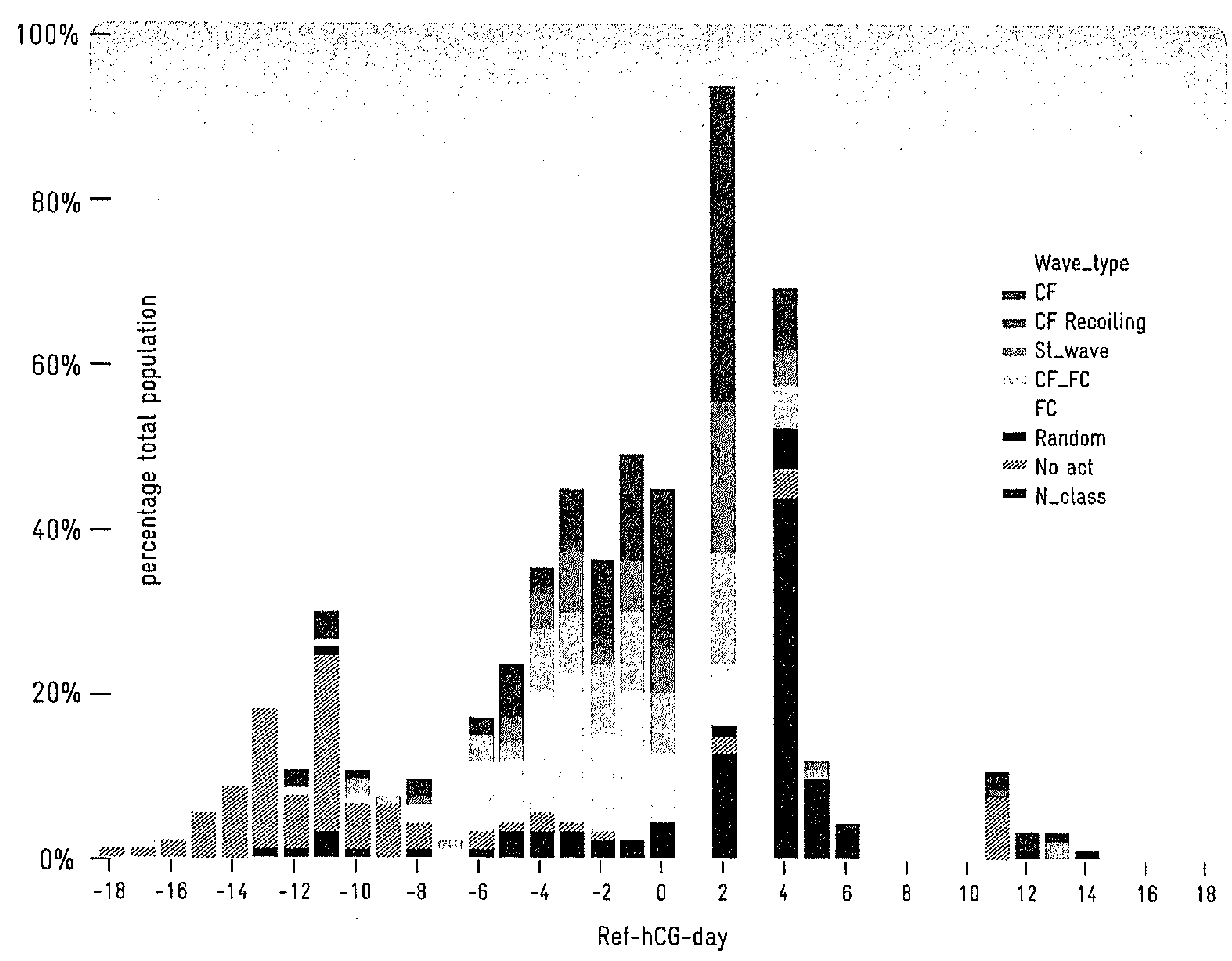




\section{Figure 2.}

Distribution of various wave-types in pregnant and non-pregnant cycles from day -8 to day 6 , related to the day of hCG administration (Ref-hCG-day).

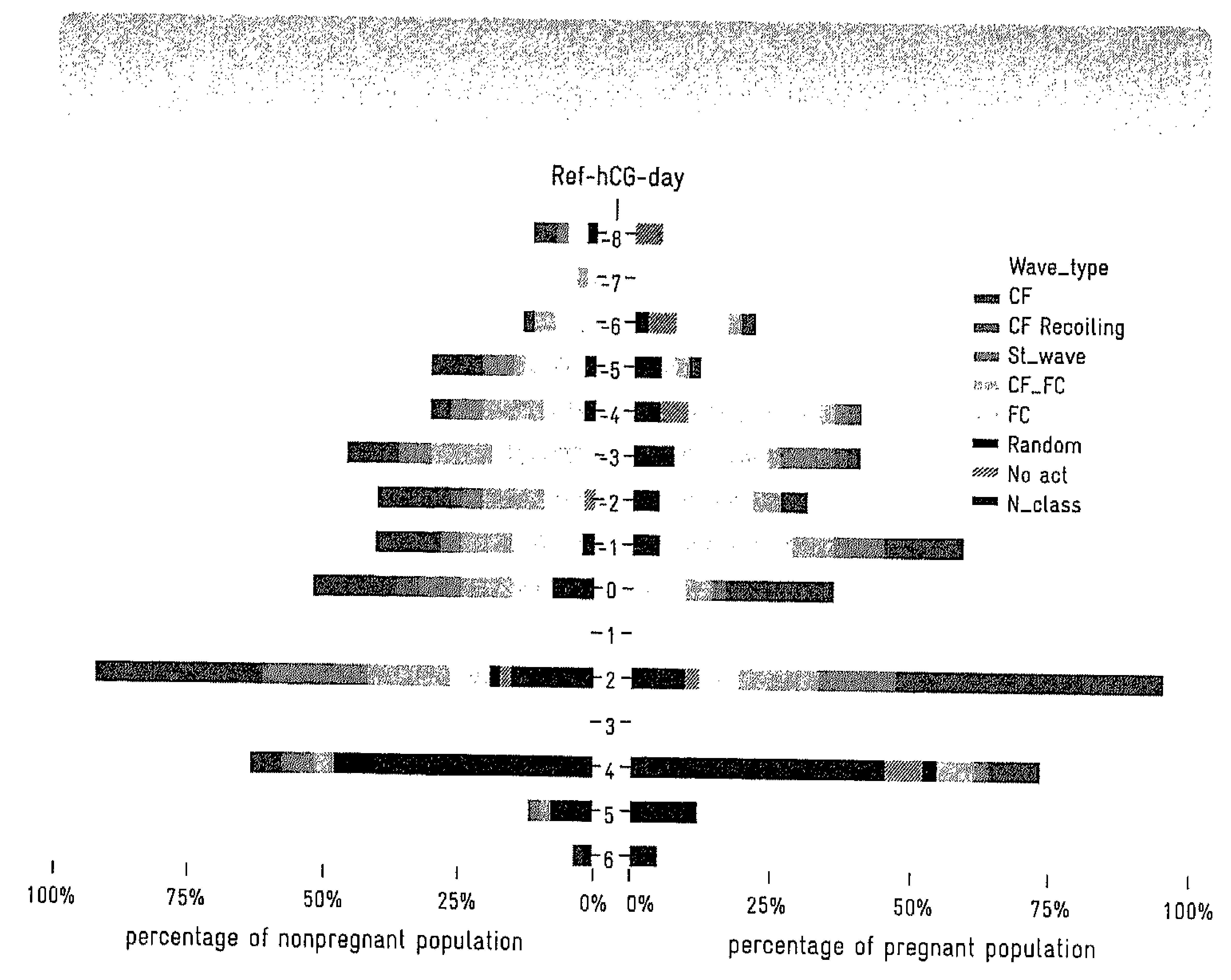




\section{Figure 3.}

Coordinated versus uncoordinated wave types in pregnant and non-pregnant cycles from day -8 to day 6 of the cycle, related to the day of hCG administration (Ref-hCG-day).

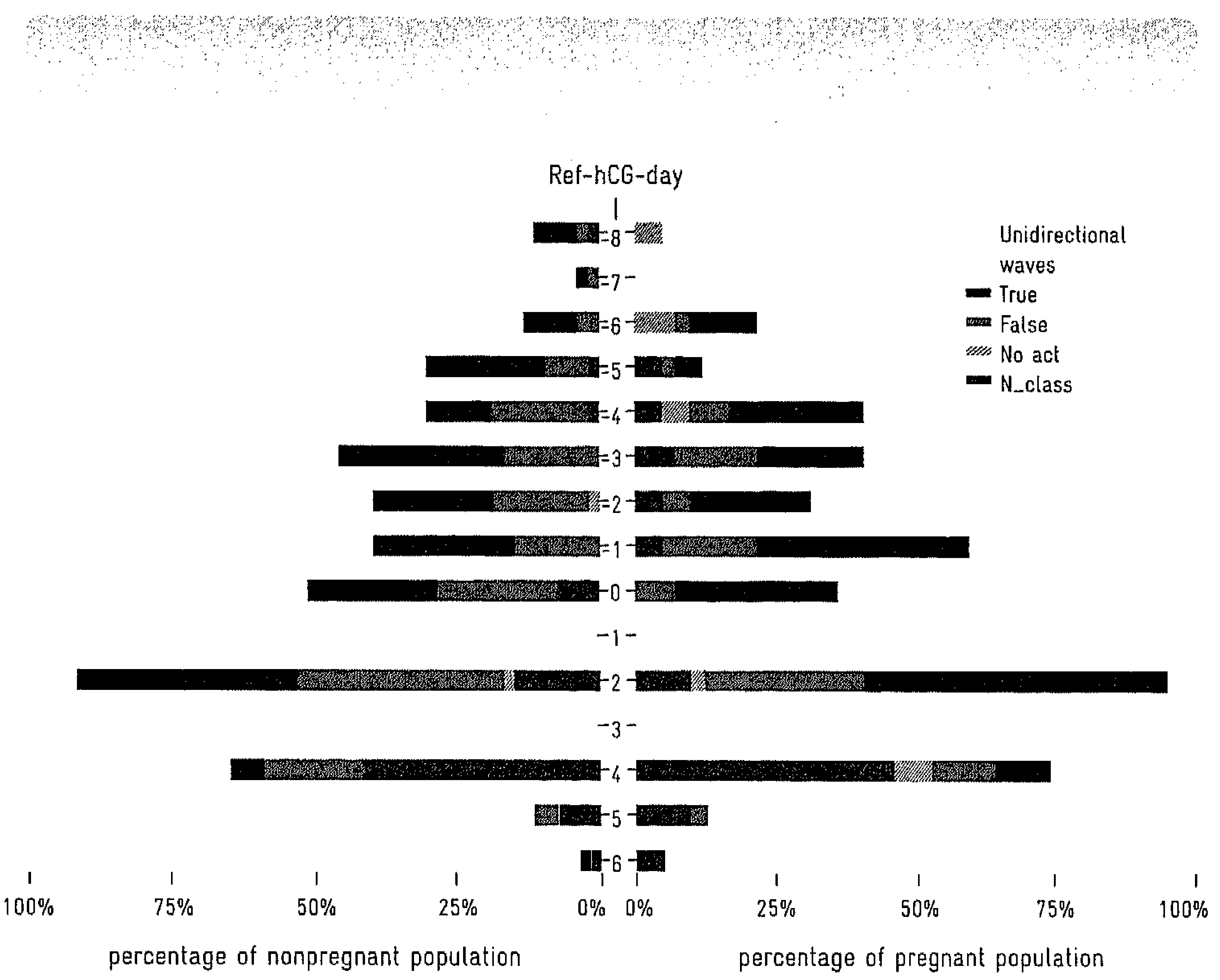


Chapter 7

General 
discussion 


\section{1 \\ General discussion}

The non-pregnant uterus shows peristaltic movements. The characteristics of these movements, such as frequency, amplitude and basal pressure, change throughout the menstrual cycle and have first been described by means of open and closed tip intra-uterine pressure recordings.

The introduction of ultrasound has made it possible to study movement in a non-invasive way. Intra-uterine pressure recording allows for describing amplitude, basal pressure and frequency. The most important advantage of ultrasound recording is that it allows for "undisturbed" observation of the direction and frequency of subendometrial uterine movements, as reflected in the endometrial waves. A disadvantage is that no impression can be obtained of uterine tone and pressure. From 1984 onwards, several authors have used ultrasound for describing uterine activity in the non-pregnant uterus. These authors used different patient groups and different moments in the cycle. Moreover, the recording techniques varied between investigators.

There was little uniformity in the different characteristics of the movements that were described, and neither was there in the classification of movements. However, consensus existed with regard to the predominant fact that movements occurred from fundus to cervix in the early follicular phase and from cervix to fundus in the late follicular and peri-ovulatory phase of the menstrual cycle. (Chapter 2, Table 2-5)

Standardisation of the description of uterine movements might contribute to better reproducible research on this subject. The lack of uniformity in describing uterine movements so far has lead IJland and co-workers (1996) to develop a classification system. The described uterine movements originate from muscular fibre contractions in the subendometrial myometrium and, since they are reflected in wavelike activity of the overlying endometrium on ultrasound recordings, the movements were called 'endometrial waves' (IJland et al., 1996). Five different wave types were distinguished (Table 1). 


\section{Table 1.}

Endometrial wave classification system according to IJland (IJland et al, 1996)

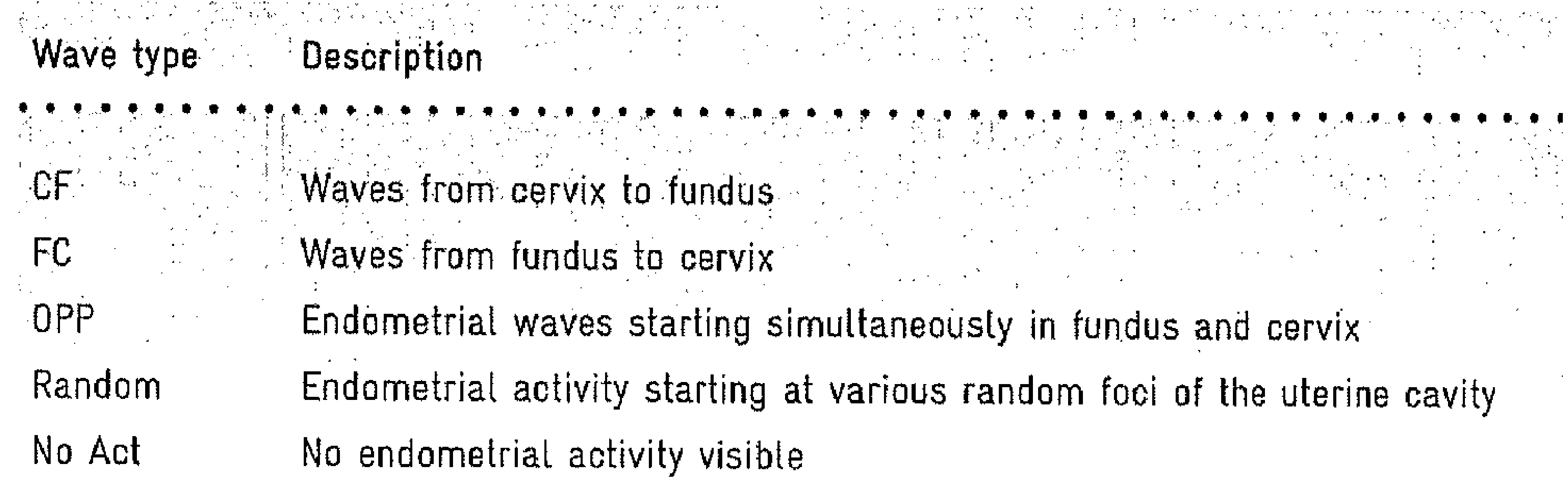

Waves from fundus to cervix (FC waves) are predominantly seen in the follicular phase and no FC waves are detected after ovulation. Given their direction towards the cervix and the (early) moment they are detected in the menstrual cycle, FC waves are presumed to play a role in the cleansing mechanism of the uterus during the early follicular phase and in denying access to the uterine cavity to possible ascending pathogens. Waves from cervix to fundus were most often recorded in the peri-ovulatory phase. A putative role for $\mathrm{CF}$ waves is that of supporting sperm transport towards the Fallopian tubes and restricting the embryo and its potential implantation site to the upper part of the uterus. Opposing waves were observed only during the first days after ovulation and might contribute to creating an environment conducive to successful nidation of the embryo. The unidirectional waves (FC waves and $\mathrm{CF}$ waves) were considered to be the most important wave types because they are most often detected and coordinated endometrial activity is presumed to be beneficial for reproduction (IJland et al., 1997).

Overall, endometrial wave-like activity is most pronounced in the peri-ovulatory phase and also the frequency of the endometrial waves is highest in this phase of the cycle. Compared to spontaneous cycles, ovulation induction cycles show more overall baseline endometrial activity, probably due to their higher estrogen levels (IJland et al., 1998 and 1999). 
Endometrial wave-like activity appeared to be related to fecundability. In spontaneous cycles, the predominance of $C F$ waves in the peri-ovulatory phase, the absence of FC waves after ovulation and an overall dampening of endometrial waves throughout the cycle seemed related to pregnancy chance (IJland et al., 1997). In IVF cycles, a lower frequency of endometrial activity at the time of embryo transfer was related to a better IVF outcome (Fanchin et al., 1998). Also the persistence of FC waves until the day of hCG administration, i.e. a late switch in direction from $\mathrm{FC}$ waves to $\mathrm{CF}$ waves, appeared to result in a better IVF outcome (IJland et al., 1999).

In the present thesis we investigated endometrial wave-like activity by means of $2 \mathrm{D}$ ultrasound. We carried out transvaginal ultrasound examinations using a $7.5 \mathrm{mHz}$ transducer. At each examination, video or DVD inages were recorded of the uterus in the midsagittal plane. The duration of the recording was standardised for each study protocol. This method of recording is comparable to methods previously reported in literature by other investigators (for review: van Gestel et al., 2003). Off-line analysis was performed at high speed replay (four times normal) after digitizing analogue signals.

The aim of the first study was to validate the results of a previous study in 22 IVF cycles (IJland et al., 1999). In this study a relation was found between the endometrial wave type on the day of hCG administration and IVF outcome. The persisting presence of FC waves until the day of hCG administration was associated with a favourable pregnancy prognosis. To validate this result in an independent larger group we prospectively examined 90 IVF patients on the day of hCG administration. We found no statistically signifcant difference in IVF outcome between the group with or without FC waves on the day of hCG administration. Therefore, we cannot confirm the findings of the previous study in an independent second group of IVF patients. This emphasizes the importance of clinical validation studies in an independent population. 
During intensive studying of endometrial wave-like activity in stimulation cycles, we observed more complex wave patterns than the wave types previously described in the literature (for review: van Gestel et al.., 2003). For example, the occurrence of more than one wave type during one recording period and also more complex wave types were encountered. Various wave patterns could not be classified according to the original criteria of the wave classification system. Because these complex wave types and combinations of wave types might be important on specific moments in the cycle and classifying endometrial activity is still a research procedure, it seems necessary to describe all endometrial activity in detail. Therefore we expanded the existing endometrial wave classification system (Table 2).

\section{Table 2.}

Revised endometrial wave classification system

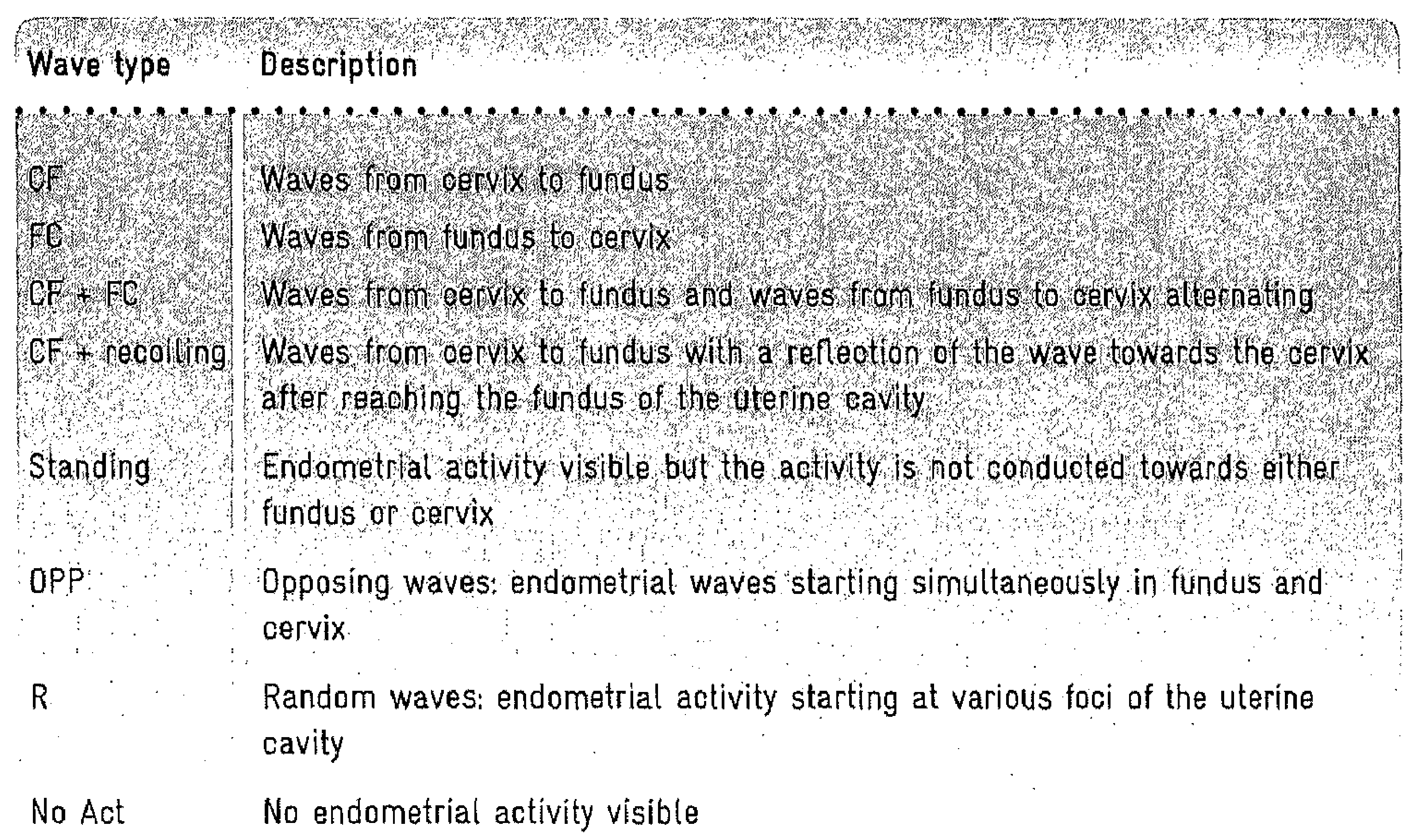


The combination of $\mathrm{CF}$ and $\mathrm{FC}$ waves, recoiling $\mathrm{CF}$ waves and a standing wave are the new components of the revised classification system. The recoiling CF wave is a wave from cervix to fundus with a recoiling of the wave towards the cervix after reaching the fundus of the uterine cavity. A standing wave pattern is not actually a wave; rather it is the pattern resulting from the presence of two or more waves of the same frequency with opposing direction. Although the refined classification system might seem more complex, intra- and interobserver agreement turned out to be very good.

Intra-uterine manipulation, for example in embryo transfer (ET) and intra-uterine insemination (IUI), is assumed to be able to trigger uterine contractions. Lesny and co-workers (1998) described the initiation of junctional zone contractions from fundus to cervix after difficult mock embryo transfers. In our study described in Chapter 5 no difference was found in the direction of endometrial waves before and after embryo transfer. In patients undergoing intra-uterine insemination there was no introduction of waves from fundus to cervix after IUI. While using the refined endometrial wave classification system we found more pure CF waves after IUI, compared to the more complex patterns that were detected before IUI. The increased proportion of pure CF waves presumably contributes to the sperm transport supporting effect towards the fundal part of the uterus, which is considered to be the physiologic wave direction during this phase of the cycle. Also the frequency of endometrial waves does not seem to be affected by intra-uterine manipulation.

Contrary to the findings of other authors, we found no adverse effect of intra-uterine manipulation on endometrial activity, not even after difficult procedures. Looking in more detail into the transfer procedure of Lesny and colleagues, they imitated a difficult procedure by deliberately touching the uterine fundus twice with the end of the catheter. This might not be completely comparable to the in vivo situation that we used in our investigations. Although the internal cervical os was sometimes more difficult to pass, and the use of a different catheter was necessary, a delicate non-touch technique was always observed. Limitations of our study might be that we describe the direction and frequency of endometrial activity, but not the actual movement of the contents of the uterine cavity. 
The more complex endometrial activity patterns described in Chapter 4 by means of the revised classification system were investigated only on the day of hCG administration in IVF cycles. While recording endometrial activity throughout the IVF cycle (Chapter 6) we have found that the complex activity patterns are not exclusively visible on this day.

We hypothesize that this complex endometrial activity might not be a normal physiological pattern, but rather an artifact resulting from supraphysiological estrogen levels. Because previous studies have also stressed the importance of calm and coordinated endometrial activity, we hypothesize that the presence of coordinated activity (CF waves or FC waves) might be beneficial for IVF outcome. In our study group however, we found no significant difference in IVF outcome between coordinated and uncoordinated activity. Also no difference was found in IVF outcome related to endometrial wave type according to the refined classification system, and neither did we find a difference in wave frequency as recorded at different moments of the IVF cycle.

The non-pregnant uterus moves throughout the menstrual cycle. Endometrial wave-like activity from fundus to cervix can be observed in the beginning of the cycle. Towards the periovulatory phase there is a switch from fundus-to-cervix activity to cervix-to-fundus activity. While using the revised endometrial wave classification system, also more complex endometrial activity can be detected, but the unidirectional waves still predominate.

After intensive studying of endometrial activity, the previously described cycle-dependant pattern can still be confirmed. Also its presumed role in the reproductive process, like cleansing of the uterus and promoting sperm transport, is still plausible. Endometrial wave studies have contributed to our understanding of the reproductive process. The use of the different characteristics of endometrial activity as a parameter to predict IVF outcome however, is not possible.

The present thesis describes the observations of endometrial activity in assisted reproduction cycles. Next to thickening and proliferation of the endometrium throughout the cycle, also its activity pattern can be recognized by ultrasound. It is tempting to presume 
a physiological role of this endometrial activity in reproduction. We conclude however, based on the findings in the present series of ultrasound recordings, that the possibilities for the clinical application of recording endometrial wave-like activity in assisted reproduction are limited.

\section{References}

1. IJland, M.M., Evers, J.L.H., Dunselman, G.A.J., van Katwijk, C., Lo, C.R., Hoogland, H.J. (1996) Endometrial wavelike movements during the menstrual cycle. Fertil. Steril., 65, 746-749.

2. IJland MM, Evers JLH, Dunselman GAJ, Volovics L, Hoogland HJ (1997) Relation between endometrial wavelike activity and fecundability in spontaneous cycles. Fertil.Steril., 67, 492-96.

3. IJland, M.M., Evers, J.L.H., Dunselman, G.A.J., Hoogland, H.J. (1998) Endometrial wavelike activity, endometrial thickness, and ultrasound texture in controlled ovarian hyperstimulation cycles. Fertil. Steril., 70, 279-83.

4. IJland, M.M., Hoogland, H.J., Dunselman, G.A.J., Lo, C.R., Evers, J.H.L. (1999) Endometrial wave direction switch and the outcome of in vitro fertilization. Fertil. Steril., 71, 476-81.

5. Fanchin, R., Rhigini, C., Olivennes, F., Taylor, S., de Ziegler, D., Frydman, R. (1998) Uterine contractions at the time of embryo transfer alter pregancy rates after in-vitro fertilization. Hum. Reprod., 13, 1968-74.

6. van Gestel I, IJland MM, Hoogland HJ and Evers JLH (2003) Endometrial wavelike activity in the non-pregnant uterus. Hum. Reprod. Update, 9, 131-8.

7. Lesny P, Killick SR, Telow RL, Robinson J, Maguiness SD. (1998) Embryo transfer- can we learn anything new from the observation of junctional zone contractions? Hum. Reprod., 13, 1540-46. 


\section{2 \\ Future perspectives}

Since complex endometrial activity patterns have only been investigated in stimulation cycles so far, it is important to investigate whether this endometrial activity can also be observed in spontaneous cycles. It is not unlikely that physiological phenomena may become disturbed when challenged by increased reproductive hormone levels. Furthermore, a more individual analysis per patient of endometrial activity throughout the cycle seems indicated. By standardizing the setting parameters of the ultrasound equipment and fine-tuning them for every individual patient, optimum image quality can be achieved for each patient in a particular investigation cycle. The investigation of individual patterns, rather than analysis of a group of patients might provide more insight in the underlying physiological processes.

By means of two-dimensional ultrasound our knowledge of the different endometrial activity patterns has further been elucidated. The development of ultra-fast MR imaging techniques might offer a new method of investigating endometrial activity. The advantage of MRI is a high tissue contrast and a good visualization of the junctional zone (subendometrial myometrium) responsible for the movement of the endometrium. The first publications on this subject indicate that cine-MRI imaging is promising in identifying further details of the endometrial activity.

Adding another dimension, in 3/4-D ultrasound, might perhaps shed a completely other light on endometrial activity. For example changes in the $3 \mathrm{D}$-recorded shape of the uterus throughout the cycle might influence the visualization of endometrial waves henceforth unrecognized. Being able to investigate the activity in more than the two dimensions we had at our disposal, could allow for a further unraveling of the endometrial activity patterns as well as the threedimensional changes in shape of the uterine cavity and of the uterus as a whole. 


\section{Summary}

The present thesis describes the ultrasound observations of endometrial wave-like activity (waves) in assisted reproduction cycles. These movements can easily be visualised by means of ultrasound and the most important characteristics that can be described are direction and frequency of the movements.

Throughout spontaneous menstrual cycles as well as stimulated cycles, waves with different directions can be detected and endometrial activity is most pronounced in the peri-ovulatory phase. The unidirectional waves, i.e. waves from fundus to cervix (FC) and waves from cervix to fundus (CF) are considered to be the most important. $\mathrm{FC}$ waves can be detected in the early follicular phase, changing into $\mathrm{CF}$ waves in the peri-ovulatory phase. Steroid hormones, estrogens and progesterone, are thought to govern this endometrial activity pattern.

The different wave-types are presumed to have a function in reproduction and previous studies have suggested a relation between endometrial wave-like activity and pregnancy chance.

The aim of the current thesis was to further elucidate different endometrial activity patterns in a larger group of women and relate the occurrence of different wave-types to the results of assisted reproduction.

In chapter 1 a general introduction is given on the subject of endometrial wave-like activity, followed by the aims of the thesis and an outline of the thesis.

A review of the literature regarding endometrial activity is presented in chapter 2. Intra-uterine pressure recordings are described, being the first method for investigating uterine activity. Subsequently ultrasound studies concerning endometrial activity are summarized, paying attention to the different methods of recording and the diversity in the description of this activity. Furthermore its presumed role in reproduction and other gynaecological conditions is discussed. 
In chapter 3 we investigated the direction of endometrial wave-like activity on the day of hCG administration in 90 patients undergoing IVF. A pilot study in a group of 22 IVF patients had shown that the persisting presence of waves from the fundus of the uterus towards the cervix, on the day of hCG administration, was associated with a favourable pregnancy chance.

In the unselected population of 90 IVF patients we found no statistically significant difference between the endometrial wave-type on the day of hCG and patient's pregnancy chance.

In chapter 4 we describe the development of a revised endometrial wave classification system. During intensive studying of endometrial movements we observed more wave types than the ones that were already described in the original wave classification system (CF- waves, FC- waves, random waves, opposing waves and no activity). We used standardised and digitally stored ultrasound material from an IVF population on the day of hCG administration, to describe endometrial activity in detail. This detailed independent description by three investigators resulted in a revised endometrial wave classification system, in which three wave types were added (CF and FC waves alternating, CF waves with recoiling of the wave and a standing wave). Statistical evaluation of the use of the revised classification system showed good intra- and interobserver agreement.

The influence of intra-uterine manipulation on the direction and frequency of endometrial wave-like activity is investigated in chapter 5. We observed endometrial activity before and after intrauterine manipulation in IVF-embryo transfer cycles and in intra-uterine insemination cycles. Contrary to some other authors we found no adverse effect of intra-uterine manipulation, in embryo transfer and intra-uterine insemination, on endometrial wave-like activity. This might be related to the technique of performing ET and IUI used in our clinic.

In chapter 6 we use the revised endometrial wave classification system prospectively, to describe endometrial activity in 94 IVF cycles. We performed ultrasound observations throughout the IVF 
cycles to study different aspects of endometrial wave-like activity and other ultrasound parameters of the endometrium. The hypothesis is tested that the occurrence of coordinated, unidirectional activity instead of more uncoordinated, non-unidirectional activity is beneficial for IVF-outcome.

The occurrence of more complex wave-types described in the revised classification system, could be confirmed in the prospective investigation of these IVF cycles. We found no statistically significant difference in the different ultrasound parameters and neither in the pregnancy chance. Also our hypothesis of coordinated endometrial activity being better for IVF outcome could not be confirmed.

In Chapter 7 the most important findings are summarized and discussed more in detail. Results are related to findings by other investigators and limitations of our studies are mentioned. Future perspectives regarding the studying of endometrial wave-like activity are also described. 


\section{Samenvatting}

In dit proefschrift wordt echoscopisch onderzoek beschreven naar golfachtige bewegingen van het endometrium (waves) tijdens fertiliteitsbevorderende behandelingscycli. Deze bewegingen kunnen eenvoudig worden gevisualiseerd door middel van echoscopisch onderzoek, waarbij de richting en de frequentie als belangrijke karakteristieken kunnen worden beschreven.

Waves met verschillende richtingen kunnen zowel in spontane cycli als gestimuleerde cycli worden waargenomen. De meeste endometriumactiviteit wordt gevonden rond het moment van de eisprong. De unidirectionele waves, dat wil zeggen waves van de fundus naar de cervix $(\mathrm{FC})$ en waves van de cervix naar de fundus $(\mathrm{CF})$ worden beschouwd als de belangrijkste. In de vroeg folliculaire fase worden met name FC waves gedetecteerd terwijl in de periode rond de ovulatie met name CF waves gezien worden. Steroidhormonen als oestrogenen en progesteron lijken dit activiteitenpatroon van het endometrium aan te sturen.

De verschillende wave-typen worden verondersteld een functie te hebben in de voortplanting en eerdere studies hebben een mogelijke relatie gevonden tussen endometriumactiviteit en de zwangerschapskans.

Het doel van het huidige proefschrift was om de verschillende activiteiten patronen van het endometrium nader te bestuderen in een grotere groep vrouwen en het voorkomen van de verschillende wave-typen te relateren aan de resultaten van geassisteerde reproductie.

In boofdstuk 1 wordt een algemene introductie gegeven over het onderwerp endometriumactiviteit, gevolgd door de doelstellingen van het proefschrift en een overzicht van de hoofdstukken.

In hoofdstuk 2 wordt een review gegeven van de tot dusver gepubliceerde literatuur betreffende endometriumactiviteit. Intrauteriene drukmetingen worden beschreven, zijnde de eerst beschreven methode om activiteit van de uterus te onderzoeken. Vervolgens worden echoscopische studies betreffende endometriumactiviteit 
samengevat, met aandacht voor de verschillende registratietechnieken en de diversiteit in de beschrijving van deze activiteit.

Verder wordt gespeculeerd over de veronderstelde rol van endometriumactviteit in de voortplanting en bij gynaecologische aandoeningen.

Een pilot onderzoek in een groep van 22 IVF patiënten had laten zien dat het nog steeds aanwezig zijn van waves van de fundus uteri naar de cervix (FC), op de dag van hCG toediening, geassocieerde was met een gunstige zwangerschapskans.

In de ongeselecteerde onderzoeksgroep van 90 patiënten beschreven in hoofdstuk 3 vonden we geen statistisch significante relatie tussen het endometrium wave-type op de dag van hCG toediening en de zwangerschapskans van deze patiente.

In hoofdstuk 4 beschrijven we een herzien classificatiesysteem voor endometriumwaves. Tijdens het intensief bestuderen van endometriumactiviteit werden meer wavetypen geobserveerd dan degene die waren beschreven in het originele classificatiesysteem voor endometriumwaves (CF waves, FC waves, random waves, opposing waves en No activity). We hebben gestandaardiseerd en digitaal opgeslagen materiaal gebruikt van een IVF populatie op de dag van hCG toediening, om endometriumactiviteit in detail te beschrijven. Deze gedetailleerde onafhankelijke beschrijving door drie onderzoekers heeft geresulteerd in een herzien classificatiesysteem voor endometriumwaves, waarin drie actviviteitspatronen zijn toegevoegd ( $\mathrm{CF}$ en $\mathrm{FC}$ waves afwisselend, $\mathrm{CF}$ waves die via de fundus uteri teruglopen in de richting van de cervix en een staande golf). Bij de statistische evaluatie van het gebruik van het herziene classificatiesysteem bleek er een goede intra- en interobserver overeenstemming te zijn.

De invloed van intra-uteriene manipulatie op de richting en frequentie van endometriumwaves is onderzocht in hoofdstuk 5. We hebben endometrium activiteit vóór en na intra-uteriene manipulatie geobserveerd in IVF embryotransfercycli en bij intra-uteriene inseminatie. In tegenstelling tot sommige andere onderzoekers hebben we 
geen nadelig effect gevonden van intra-uteriene manipulatie, zoals bij embryo transfer en intra-uteriene inseminatie, op endometrium waves. Dit zou kunnen liggen aan de techniek waarmee ET en IUI in onze kliniek wordt uitgevoerd.

In hoofdstuk 6 gebruiken we het herziene classificatie systeem voor endometriumwaves prospectief om endometrium activiteit te beschrijven in 94 IVF cycli. We hebben echoscopisch observaties gedaan gedurende de IVF cycli om de diverse aspecten van endometriumwaves en andere echoscopische parameters van het endometrium te bestuderen. De hypothese is getest dat het vóórkomen van gecoördineerde, unidirectionele activiteit in plaats van meer ongecoördineerde, niet-unidirectionele activiteit, gunstig is voor de IVF uitkomst.

De meer complexe wavetypen zoals beschreven in het herzien classificatie systeem, konden ook worden onderscheiden tijdens het prospectief onderzoek in deze IVF cycli.

Er wordt geen statistisch significant verschil gevonden in de diverse echoscopische parameters van het endometrium en ook niet in de zwangerschapskans. Ook onze hypothese dat gecoördineerde endometriumactiviteit beter zou zijn voor de IVF uitkomst kon niet worden bevestigd.

In hoofdstuk 7 worden de belangrijkste bevindingen samengevat en meer gedetailleerd besproken. De resultaten worden gerelateerd aan de bevindingen van andere onderzoekers en de beperkingen van onze studies worden genoemd. Toekomstige mogelijkheden voor het nader bestuderen van endometrium activiteit worden eveneens beschreven. 


\section{Curriculum Vitae}

Iris van Gestel is geboren op 8 april 1970 in Venray. In 1988 voltooide zij het VWO aan het Bosschveldcollege te Venray. Zij behaalde haar propedeuse Gezondheidswetenschappen en startte aansluitend met de studie geneeskunde aan de Rijksuniversiteit Limburg (thans universiteit Maastricht). In juni 1996 behaalde zij haar artsexamen en begon in de Vroedvrouwenschool te Kerkrade als AGNIO gynaecologie. In augustus 1998 startte zij de opleiding tot gynaecoloog in het Atrium Medisch Centrum Heerlen onder leiding van Dr. J. E. G. M. Stoot en later Dr. F. J. M. E. Roumen. Vanaf augustus 2000 vervolgde zij haar opleiding in het academisch ziekenhuis Maastricht onder leiding van Prof. J. L. H. Evers. Naast het klinisch werk werd gestart met het onderzoek beschreven in dit proefschrift. Het onderzoek werd uitgevoerd binnen het onderzoeksinstituut Groei en Ontwikkeling (GROW) en de afdeling Obstetrie en Gynaecologie. Het project werd mede mogelijk gemaakt door een subsidie van het Profileringsfonds.

In december 2004 werd zij als gynaecoloog ingeschreven in het Specialisten Register en sindsdien is zij werkzaam in het VieCuri, Medisch Centrum voor Noord-Limburg. 


\section{Dankwoord}

Het schrijven van dit proefschrift had natuurlijk niet tot stand kunnen komen zonder de hulp van anderen. Een start maken met het onderzoek, maar met name ook het volhouden was zonder jullie hulp niet gelukt. Hoewel mijn liefde duidelijk uitgaat naar het werken als klinicus, heeft het wetenschappelijk onderzoek me de mogelijkheid gegeven mijn horizon te verbreden.

Professor Evers, beste Hans. Al in 2000 zijn Peter Bouckaert en ik naar jou werkkamer in het azM gekomen om te kijken of er voor mij mogelijkheden waren om wetenschappelijk onderzoek te doen en misschien te zijner tijd zelfs wel te promoveren. De hoop dat dat ook daadwerkelijk zou lukken ben je wellicht gaandeweg wel eens kwijtgeraakt. Toch heb je altijd op de juiste momenten mij het vertrouwen gegeven dat we op de juiste weg zaten. Je kritische bijdrage aan de wetenschappelijke publicaties en je mooie formuleringen in de Engelse taal hebben mij zeer geholpen.

Henk Hoogland, zonder jou tomeloze energie was dit boekje er zeker nooit gekomen. Jou bereidheid om steeds maar weer de draad op te pakken en samen met mij op woensdag aan de slag te gaan met de "waves" bewonder ik zeer. En natuurlijk je gedrevenheid om door te gaan tot in de nachtelijke uren als je ergens mee aan de slag was; ik wou dat ik een fractie hiervan had. Jouw bijdrage in de technische bewerking van de opnames, de statistiek en je opmerkingen bij de wetenschappelijke stukken waren onmisbaar.

Marga IJland, je bent me voorgegaan in het onderzoek naar de waves. Nadat ik eerst jou jonge collega assistent was in Heerlen, werd je mijn baas in het azM en begeleider in dit onderzoek. Inmiddels ben ik een collega en hebben we hetzelfde aandachtsgebied, de bekkenbodem. Als moeders in een gezin met jonge kinderen was er soms teveel wederzijds begrip voor een gebrek aan tijd voor het onderzoek, ook als deadlines hierdoor niet gehaald werden. Anderzijds was jij altijd degene die me aanmoedigde door te gaan en vertrouwen te houden dat die promotie er wel zou komen. Dank voor je bijdrage in gehele onderzoek waarvoor jij toch de basis hebt 
gelegd. Ik hoop dat onze vriendschap voortduurt na het afsluiten van dit "project".

Christine Willekes, je hebt mij wegwijs gemaakt in mijn eerste weken als assistent in het azM op de polikliniek. Tijdens onze fertiliteits-stage heb je me geholpen opnames te maken voor en na de inseminaties en je hebt in die tijd ook deel uit gemaakt van onze onderzoeksbesprekingen. Aan het einde van mijn opleiding heb je me toegesproken tijdens het assistentensymposium. Je noemde me een dieseltrein, die langzaam op gang komt maar het wel lang volhoudt. Nou Christine, deze diesel heeft het station promotie dan toch bereikt! Dank voor je bijdrage. Veel geluk in je persoonlijke leven en met je carrière komt het vanzelf wel goed.

Janneke den Hartog, Kim van Kaam, Annemiek Nap, Tanja Gijsen en medewerkers van de IVF afdeling. Het grootste deel van mijn onderzoek heeft zich afgespeeld bij IVF patiënten. Ik heb dan ook veel tijd op jullie afdeling doorgebracht. De prettige sfeer en de bereidheid om mij te helpen bij het benaderen van patiënten of het opzoeken van gegevens heb ik als zeer prettig ervaren. Ook van patiënten hoorde ik, tijdens de opnames die ik maakte, zo'n goede verhalen over jullie betrokkenheid en zorgzaamheid. Heel erg bedankt voor jullie hulp bij mijn onderzoek.

Patiënten die hebben deelgenomen aan mijn onderzoek. Ongelooflijk was de bereidheid van vele patiënten om, naast het onderzoek wat ze toch al moesten ondergaan, ook nog eens bij mij een extra echo te laten maken. Vanuit het oogpunt dat mogelijke toekomstige patiënten hiervan profijt zouden kunnen hebben, zeiden de meeste patiënten ja tegen deelname aan wetenschappelijk onderzoek. Bedankt voor jullie tijd.

Peter Bouckaert, een onderzoekstage door jou georganiseerd in de Vroedvrouwenschool heeft de basis gelegd voor mijn opleiding tot gynaecoloog. Nadat ik werd angenomen als AGNIO heb ik een zeer leerzame en leuke tijd gehad. Bij het "afscheidsdiner" in restaurant de Leuf heb jij mij toegesproken, zoals jij dat zo goed kan. Jij gaf toen aan dat het voor mij tijd werd promotieonderzoek te gaan doen 
en dat jij mij daarbij wilde begeleiden. Helaas is het in de praktijk anders gelopen. Ik ben je heel dankbaar dat je het manuscript hebt willen beoordelen en dat je wilt plaatsnemen in de Corona.

Frans Roumen, je bent een belangrijke initiator geweest voor het ontplooien van wetenschappelijke activiteiten. Al voordat ik in opleiding kwam werd ik aangezet tot schrijven van twee artikelen en het geven van diverse presentaties. Maar ook in de klinische werkzaamheden had jij een duidelijke sturende functie. Het steeds weer op uniforme wijze uitvoeren van operaties was voor een beginnend assistent heel prettig. Vervolgens was het prettig om bij anderen te leren dat er wellicht meerdere wegen zijn die naar Rome leiden. Een gevleugelde uitspraak van jou schiet nog steeds regelmatig door mijn hoofd als ik op de operatiekamers bezig ben: "alleen perfectie is goed genoeg".

Collega's VieCuri, inmiddels ben ik bijna 4 jaar onderdeel van onze maatschap. Destijds was mijn keuze om naar het VieCuri te komen in het bijzonder ingegeven door de prettige sfeer die ik tijdens de sollicitatiegesprekken had ervaren. Inmiddels kan ik zeggen dat ik met veel plezier in Venlo en Venray werk met jullie als collega en hoop dat nog lang te blijven doen. Bedankt voor jullie steun in de afronding van mijn proefschrift.

Maartje en Mirjam, wat een prettig gevoel dat jullie mij bijstaan in de aanloop naar de promotie en tijdens de verdediging van mijn proefschrift. Maartje, hartsvriendin sinds ons werk bij Charlemagne en de oefensessies voor de voortgangstoets. Hoewel minder frequent na je verhuizing naar Amsterdam, niet minder belangrijk. Ik vind het fijn dat ik ook jou binnenkort mag bijstaan in een voor jou belangrijke gebeurtenis. Mirjam, samen gestart in het azM en nu werkzaam binnen hetzelfde aandachtsgebied zodat we gezamenlijk congressen kunnen bezoeken. Jou onderzoek begint nu ook vorm te krijgen en ik wens je heel veel succes met de uitvoering ervan.

Marieke, als rode draad door de belangrijke gebeurtenissen in mijn leven heb jij "de vormgeving" altijd verzorgd. Onze trouwkaart, de geboortekaartjes en nu het grootste project: mijn boekje. Steeds 
heb je me weer verrast met je creativiteit en ik bewonder je vakmanschap. De "werkbespreking" halverwege is voor herhaling vatbaar, ook al is het werk gedaan. Heel erg bedankt dat je naast je drukke werkzaamheden hier tijd voor hebt vrij willen maken.

Papa en mama, de basis van alles ligt bij jullie. Jullie hebben mij gevormd tot wie ik ben. Misschien niet de snelste, maar wel met doorzettingsvermogen. Ondanks jullie aanvankelijke twijfel of het wel de juiste keuze was voor mij on geneeskunde te gaan studeren, zien jullie inmiddels dat ik mijn vak met veel plezier uitoefen. Jullie doen er alles aan om dit te faciliteren, door waar maar mogelijk op Annelieke en Teun te passen en ons veel werk uit handen te nemen. Daardoor was het mogelijk naast mijn werk onderzoek te doen en heel wat vrije dagdelen in Maastricht door te brengen. Ik ben jullie hiervoor oneindig dankbaar!

Maarten, pas getrouwd en met twee prachtige kereltjes ben je aan een nieuwe fase in je leven begonnen. Ondanks de drukte van de dagelijkse beslommeringen geniet je samen met Saskia nog steeds met volle teugen van allerlei sociale activiteiten. Hoewel opgeschrikt door hernieuwde hersenbloedingen in de afgelopen jaren, blijf jij onze rasoptimist. Je bent de eerste om, ondanks je eigen zorgen, onze tranen weer om te zetten in een lach. Ik ben er trots op jou zus te zijn en wens jou samen met Saskia en de boys een fantastische toekomst.

Jos, mijn lief. Jij hebt er nooit aan getwijfeld dat dit proefschrift er zou komen. Je bent vol vertrouwen over mijn capaciteiten, hoewel misschien niet altijd op reële gronden gebaseerd. De afgelopen jaren waren erg druk en er wordt heel wat aanpassing van jou gevraagd, zodat ik mijn werk en onderzoek kan doen. Dat is niet altijd gemakkelijk, maar we worden we een steeds beter team. Nu deze last bijna van mijn schouders is kunnen we heerlijk samen gaan genieten.

Annelieke en Teun

Jullie zijn mijn leven! 